\title{
CONTEÚDO DE CARBONO NA BIOMASSA FLORESTAL DA AMAZÔNIA E ALTERAÇÕES APÓS À QUEIMA
}

\author{
PAULO MAURÍCIO LIMA DE ALENCASTRO GRAÇA \\ Engenheiro Florestal
}

Orientador: Prof. Dr. Carlos Clemente Cerri

Dissertação apresentada à Escola Superior de Agricultura "Luiz de Queiroz". da Universidade de São Paulo, para obtenção do título de Mestre em Ciências Florestais

PIRACICABA

Estado de São Paulo - Brasil

Abril - 1997 
Dados Internacionais de catalogação na Publicação <CIP) DIVISÃO DE BIBLIOTECA E DOCUMENTAÇÃO - campus fflulz de Queiroz"/USP

Graça, Paulo Maurício Lima de Alencastro

Conteúdo de carbono na biomassa florestal da amazônia e alterações após à queima/ Paulo Mauricio Lima de Alencastro Graça. • P Piracicaba, 1997.

105 p.: li.

Dissertação (mestrado) - E Escola Superior de Agricultura Luiz de Queiroz, 1997.

Bibliografia.

1. Amazônia 2. Biomassa florestal 3. Carbono 4. Desmatamento 5. Impacto ambiental

CDD 634.983

333.7514 


\title{
CONTEÚDO DE CARBONO NA BIOMASSA FLORESTAL DA AMAZÔNIA E ALTERAÇÕES APÓS À QUEIMA
}

\author{
PAULO MAURÍCIO LIMA DE ALENCASTRO GRAÇA
}

Aprovada em: 07/04/97

Comissão Julgadora:

Prof. Dr. Carlos Clemente Cerri

CENA/USP

Prof Dr. Reynaldo Luiz Victória

CENA/USP

Prof Dr. José Leonardo de Moraes Gonçalves

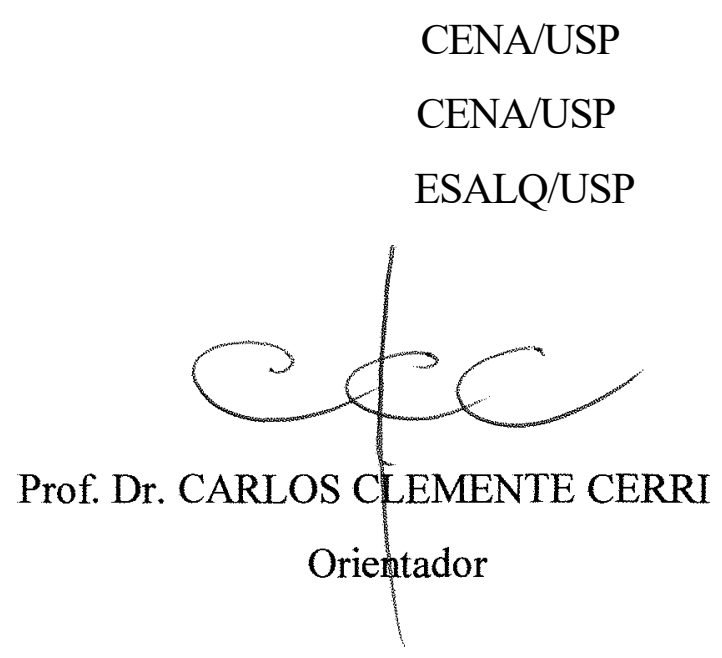




\section{AGRADECIMENTOS}

- Agradeço em especial ao Dr. Carlos C. Cerri pela orientação e amizade.

- Ao Instituto Nacional de Pesquisa na Amazônia (INPA) por permitir a realização deste trabalho.

- Ao CNPq pelo suporte financeiro.

- Ao pesquisador Dr. Philip Fearnside pela amizade e colaboração nesta pesquisa.

- À Seção de Química do Solo (CENA/USP) pelo apoio logístico, em especial às pesquisadoras Dra. Brigitte Feigl e Dra. Marisa Piccolo.

- À secretária da seção Mara Piacentini e aos técnicos de laboratório José Roberto Martins, Sandra Nicoleti e as estagiárias Márcia e Roberta, e ao Sr. Dacir Bortoleto.

- Aos amigos da pós-graduação Marciano Brito, Martial Bernoux, Dinailson Campos, Solismar Venzke, Maria Conceição Carvalho, Silvana Fernandes e João Carlos Sá.

- Aos pesquisadores Christopher Neill e Paul Steudler (Ecosystem Center).

- Aos pesquisadores, Frederique, Patrick Seyler e Boris Volkoff( ORSTOM).

- Ao pesquisador Dr. Niro Higuchi (INPA).

- Ao Departamento de Ciências Florestais da Esalq- USP a todos os professores, em especial ao Prof. Fabio Poggiani, Prof. José Leonardo e Prof. Paulo Kageyama.

- À Biblioteca do IPEF, aos bibliotecários Marialice Poggiani e Paulo.

- Aos companheiros de turma da floresta.

- Ao laboratório de Hidrologia, Ecologia e Nutrição Florestal (ESALQ), aos técnicos Marcos e Alba.

- Ao laboratório de Celoluse e Papel (ESALQ) em especial ao técnico Udmilson.

- À seção de Hidrologia e Isótopos Estáveis (CENA), ao técnico Pingim.

- Ao Sr. João Arantes Júnior, proprietário da Faz. Nova Vida (Rondônia).

- À Sonia Cristina pela sua companhia e solidariedade durante este trabalho.

- E a todos os demais colegas e Instituições que de uma forma ou de outra colaboraram para a conclusão deste trabalho. 


\section{SUMÁRIO}

Página

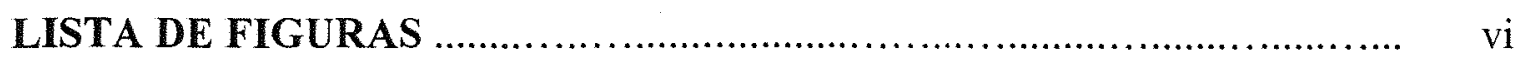

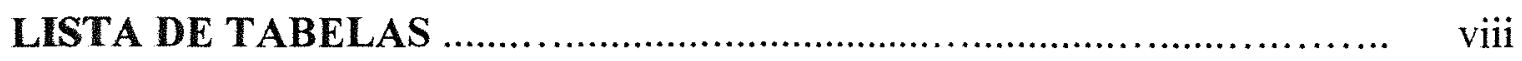

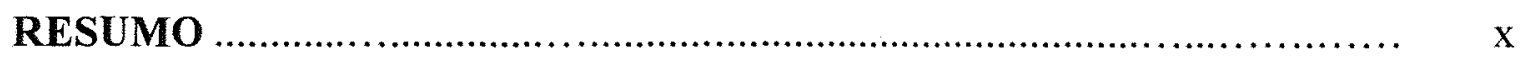

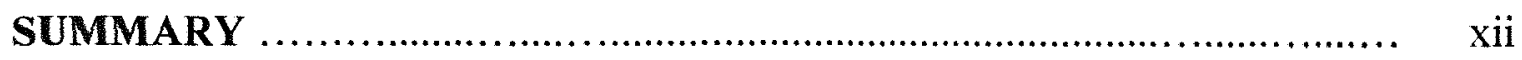

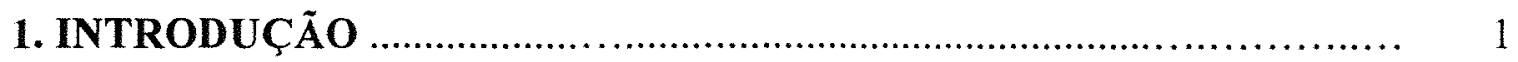

2. REVISÃO DE LITERATURA ….....................................................

2.1. As florestas tropicais e o ciclo global do carbono .............................. 3

2.2. A Amazônia e a emissão de carbono pelas queimadas ........................ 5

2.2.1. Tipos de Vegetação na Amazônia ............................................... 6

2.2.2. Fitomassa na Amazônia ......................................................... 12

2.2.2.1. Métodos empregados para estimar a fitomassa na Amazônia .................................................................. 13

2.2.3. Extensão do desmatamento na Amazônia Legal ........................ 16

2.2.4. Emissões de $\mathrm{CO}_{2}$ pelo desmatamento na Amazônia ................ 19

2.2.4.1. A prática de corte e queima na Amazônia ................. 21

3. MATERIAL E MÉTODOS …......................................................... 29

3.1. Localização, vegetação, solo e clima da Amazônia Legal ................ 29

3.2. Localização e caracterização ambiental da área de estudo em Rondônia 33

3.3. Estimativa da fitomassa e do estoque de carbono para Amazônia Legal 36

3.3.1. Elaboração do mapa de vegetação .......................................... 36

3.3.2 Classificação da vegetação do mapa ........................................... 37

3.3.3. Cálculos para estimar a área de cada tipo de vegetação ........... 39

3.3.4. Cálculos para estimar a fitomassa ........................... 39

3.3.5. Cálculos para estimar o estoque de carbono da vegetação ........ 43

3.4. Estimativa e transformações da fitomassa em Rondônia .................. 43 
3.4.1.Estimativa da biomassa florestal em pé por inferência alométrica..

3.4.2 Avaliação das transformações da biomassa florestal aérea pela

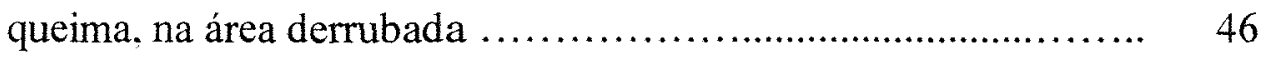

3.4.2.1. Método de colheita destrutiva (direto) .................... 47

3.4.2.2. Método de amostragem por interseção de linhas ........... 54

3.4.2.3. Modificações no estoque de carbono no solo após a queima

4. RESULTADOS E DISCUSSÃO …................................ 59

4.1. Interpretação e medição das áreas de vegetação Amazônia Legal ........ 60

4.2. Biomassa e estoque de carbono da vegetação florestal na Amazônia ..... 62

4.3. Biomassa da vegetação com formação não florestal ....................... 65

4.4. Estimativa e transformações da fitomassa na área estudada na fazenda

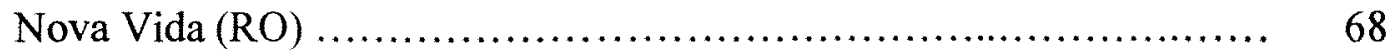

4.4.1. Estimativa da biomassa da floresta em pé na área de estudo ..... 68

4.4.2. Biomassa aérea na área derrubada antes da queima ................ 71

4.4.3. Fitomassa acima do solo após a queima .............................. 76

4.4.4. Formação de carvão e cinzas ............................................ 77

4.4.5. Eficiência de combustão e liberação de carbono durante a

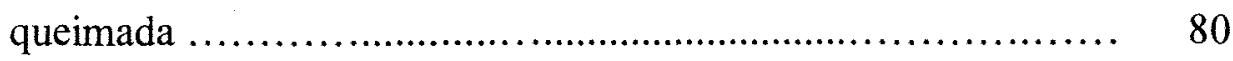

4.6. Mudanças no estoque de carbono no solo após a queima da vegetação.... 86

4.7. Contribuição da queima da biomassa florestal para a emissão de carbono

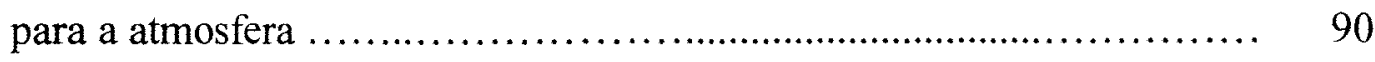

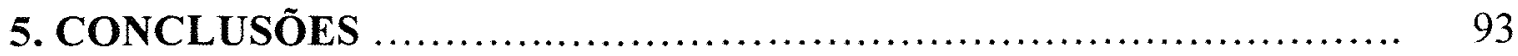

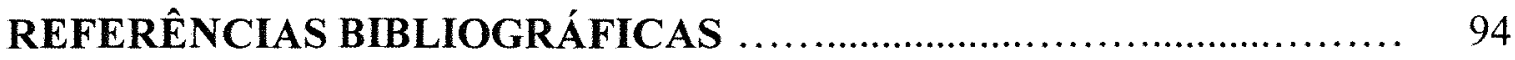




\section{LISTA DE FIGURAS}

\section{Página}

Figura 1. Esquema simplificado do ciclo global do carbono ..............................

Figura 2. Mapa esquemático da localização da Amazônia Legal ......................... 29

Figura 3. Perfis esquemáticos de três principais ecossistemas da Amazônia ...... 30

Figura 4. Distribuição relativa de dezessete classes de solo na Amazônia Legal de acordo com o sistema de classificação da Empresa Brasileira de Pesquisa Agropecuária (EMBRAPA), adaptado de Moraes et al. (1995)

Figura 5. Tipos climáticos da Amazônia segundo o sistema de classificação de Köppen (adaptado de Vieira \& Santos, 1987) ................................... 32

Figura 6. Mapa esquemático da localização da Fazenda Nova Vida ................... 33

Figura 7. Imagem Landsat/TM (composição colorida 3B4G5R) apresentando a área da Fazenda Nova Vida

Figura 8. Médias mensais de temperatura e precipitação, no período de 1988 a 1992, na Fazenda Rancho Grande, Ariquemes - RO ...

Figura 9. Esquema das parcelas de levantamento florestal

Figura 10. Esquema da área experimental localizada na Fazenda Nova Vida em Ariquemes Rondônia

Figura 11. Mapa de vegetação, elaborado neste estudo, apresentado as áreas ocupadas pelas principais formações vegetais na Amazônia Legal ...

Figura 12. Relação entre os estoques de biomassa $\left(\mathrm{t} \mathrm{ha}^{-1}\right)$ para a classe de madeira $\geq 10 \mathrm{~cm}$ de diâmetro obtidos pelos os métodos indireto $\mathrm{e}$ direto, após a queima 
Figura 13. Relação entre os estoques de carvão para a classe de madeira $\geq 10 \mathrm{~cm}$ de diâmetro obtidos pelos os métodos indireto e direto, após a queima

Figura 14. Percentual de consumo de fitomassa acima do solo pela queima por tipo de material e classe de diâmetro

Figura.15. Comparação entre a distribuição aproximada dos compartimentos da fitomassa acima do solo antes de queimar e depois da queima, por tipo material combustível e classe de diâmetro $(\mathrm{cm})$

Figura 16. Distribuição relativa do carbono após a queimada em Ariquemes .....

Figura 17. Destino do carbono da fitomassa aérea, antes e imediatamente após a queima

Figura 18. Valores médios de teores de carbono nos sistemas estudados para cada profundidade amostras, nas datas de coleta. As interações entre os três efeitos foram analisados atraves da Análise de Variância (ANOVA) 


\section{LISTA DE TABELAS}

Página

Tabela 1. Estimativas mais recentes para biomassa florestal na Amazônia a partir de levantamentos em escala regional

Tabela 2. Características químicas e físicas do solo sob a floresta na Fazenda Nova Vida, Ariquemes, RO

Tabela 3. Tipos de vegetação representados no mapa da Amazônia Legal

Tabela 4. Parâmetros para derivar a estimativa de fitomassa de dados de volume florestal do RADAMBRASIL

Tabela 5. Fatores para conversão de volume de lenha de savanas (st ha $\mathrm{ha}^{-1}$ em biomassa total $\left(\mathrm{t} \mathrm{ha}^{-1}\right)$, a partir dos dados do RADAMBRASIL ........

Tabela 6. Biomassa, estoques de carbono e número de amostras levantadas em áreas de florestas presentes na Amazônia Legal

Tabela 7. Biomassa e estoque de carbono da vegetação não florestal na Amazônia Legal 66

Tabela 8. Dados obtidos no levantamento florestal de 1 ha 68

Tabela 9. Distribuição de frequência de indivíduos, estoque de biomassa (em toneladas) por classe e percentual de biomassa por classe de DAP (cm) na área amostrada de 1 ha.

Tabela 10. Percentual de umidade das amostras vegetais por tipo de material combustível e classe de diâmetro $(\mathrm{cm})$, na fase antes da queima ......

Tabela 11. Estoque de fitomassa sobre o solo, antes da queima, em cada compartimento e seu percentual em relação a biomassa total .........

Tabela.12. Distribuição aproximada do estoque de biomassa acima do solo da 
floresta $\left(\mathrm{t} \mathrm{ha}^{-1}\right)$ em áreas de derrubada em várias localidades na Amazônia, antes da queima

Tabela 13. Estoque de fitomassa remanescente sobre o solo, depois da queima, em cada classe de material e seu percentual em relação a biomassa total

Tabela 14. Resultados encontrados para quantidade de cinzas $\left(\mathrm{t} \mathrm{ha}^{-1}\right) \mathrm{em}$ queimadas na Amazônia

Tabela 15. Distribuição do carbono da biomassa acima do solo e carbono liberado na Fazenda Nova Viva, RO

Tabela 16. Estoque de carbono nos solos dos sistemas alterado e natural, nas camadas de 0-10, 10-20, 20-30 cm, no período de um ano de amostragem 


\title{
CONTEÚDO DE CARBONO NA BIOMASSA FLORESTAL DA AMAZÔNIA E ALTERAÇÕES APÓS À QUEIMA
}

\author{
Autor: PAULO MAURÍCIO LIMA DE ALENCASTRO GRAÇA \\ Orientador: PROF. DR. CARLOS CLEMENTE CERRI
}

\section{RESUMO}

O carbono contido nos vários tipos de vegetação da Amazônia Legal foi estimado, com base nos dados da literatura, em $80 \mathrm{Pg}$. Este valor representa $14 \%$ do conteúdo de carbono da vegetação de todos os ecossistemas do globo terrestre. Deste total. 95\% (78 Pg) estão estocados nas florestas, as quais ocupam 74\% da Amazônia. O restante do carbono ( $2 \mathrm{Pg}$ ) está estocado em $24 \%$ da área total da Amazônia, principalmente. nas savanas (cerrados), campinas e nas áreas de atividades antrópicas. A biomassa aérea média da floresta é de $304 \mathrm{t} \mathrm{ha}^{-1}$. Incluindo-se os componentes da necromassa e da biomassa subterrânea, o valor médio encontrado é de $422 \mathrm{t} \mathrm{ha}^{-1}$.

As transformações pela queima da biomassa foram avaliadas para uma floresta aberta localizada na fazenda Nova Vida, em Ariquemes, RO. A biomassa aérea antes da queima foi estimada em $313,3 \mathrm{tha}^{-1}$ e corresponde a um estoque de carbono de $152,5 \mathrm{t} \mathrm{ha}^{-1}$. Após a queima este estoque foi reduzido em $34,6 \%$ (eficiência de combustão). Isto implica numa transferência de $49,4 \mathrm{tC} \mathrm{ha}^{-1}$ para a atmosfera. A quantidade de carbono no carvão e nas cinzas formados correspondem a apenas $3 \%$ do estoque de carbono total presente antes da queima. Os métodos direto (destrutivo) e indireto (amostragem por linhas de interseção), para estimar a biomassa após a queima e o carvão. foram comparados e apresentaram um coeficiente de correlação de 0,91 . 
A distribuição da biomassa inicial entre as classes de material vegetal explicou, em grande parte, as diferenças entre os valores de eficiência de combustão encontrados na Amazônia. A alta variabilidade entre as florestas implica em novos estudos para que seja alcançada uma estimativa média de eficiência de combustão mais confiável.

Considerando-se os valores encontrados para a eficiência de combustão, em Ariquemes e de outras localidades na Amazônia, estimou-se uma quantidade de 2,9 Pg de carbono liberado no momento da queima das florestas da Amazônia Legal, dos $470 \times 10^{3}$ $\mathrm{km}^{2}$ desflorestados até 1994. A contribuição anual de carbono emitido para a atmosfera foi de 92,0 $\mathrm{Tg} \mathrm{C}$ ano ${ }^{-1}$, para o período de 1992 a 1994. Este fluxo anual correspondeu a 6 $\%$ das emissões, causadas pelas mudanças no uso da terra nos trópicos. 


\title{
CARBON CONTENT OF AMAZON FOREST BIOMASS AND CHANGES AFTER BURNING
}

\author{
Author: PAULO MAURÍCIO LIMA DE ALENCASTRO GRAÇA \\ Adviser: Orientador: PROF. DR. CARLOS CLEMENTE CERRI
}

\section{SUMMARY}

The carbon contained in the various types of vegetation in the Brazilian Legal Amazon was estimated at $80 \mathrm{Pg}$, based on data from the literature. This value represents $14 \%$ of the carbon contained in vegetation of all terrestrial ecosystems on Earth. Of this total, 95\% (78 Pg) are stocked in the forests, which occupy $74 \%$ of the Legal Amazon. The remaining carbon ( $2 \mathrm{Pg}$ ) is stocked in $24 \%$ of the total area of the Amazon, mostly, in savannas, "campinas", and areas of human activities. The average aboveground forest biomass is $304 \mathrm{MT} \mathrm{ha}^{-1}$. Including dead and belowground biomass components, the estimated mean value is $422 \mathrm{MT} \mathrm{ha}^{-1}$.

Transformations of biomass caused by burning was assessed in an open forest located in Nova Vida Ranch, Ariquemes, RO. The initial aboveground biomass was estimated at $313.3 \mathrm{t} \mathrm{ha}^{-1}$ and corresponded to $152,5 \mathrm{t} \mathrm{ha}^{-1}$ of the carbon stock. After burning, this stock was reduced by $34 \%$ (combustion efficiency). This implies in a transfer of $49.4 \mathrm{t} \mathrm{C} \mathrm{ha}^{-1}$ to the atmosphere. The carbon stocked in the resulting charcoal and ashes corresponds only to $3 \%$ of the total carbon stock present before burning. The direct (destructive) and the indirect (line intersect sampling) method to estimate the biomass and charcoal after burning were compared and correlation coefficients after burning of 0.91 were obtained. 
The differences between values of combustion efficiency in the Amazon are explained primarily by differences in the initial distribution of biomass among fractions, such as vines and litter. The high variability among forests implies in more studies to reach a more reliable mean value of combustion efficiency.

Considering the values of combustion efficiency from Ariquemes and other localities in the Amazon, the carbon released upon burning was calculated at $2.9 \mathrm{Pg}$ from the total area $\left(470 \times 10^{3} \mathrm{~km}^{2}\right)$ deforested up to 1994 in Legal Amazon. The annual contribution of carbon emitted to the atmosphere was $92.0 \mathrm{Tg} \mathrm{C}$ year ${ }^{-1}$ for the period from 1992 to 1994 . This annual flux represents $6 \%$ of the emissions due to changes in land use changes tropics. 


\section{INTRODUÇÃO}

Uma das maiores preocupações mundiais da atualidade é o aumento da concentração de dióxido de carbono na atmosfera e o seu potencial em alterar o clima global. Apesar de, em grande parte, essas emissões serem originadas pela queima de combustiveis fósseis, a queima de florestas tropicais também tem contribuído para as emissões globais de carbono. Estima-se que cerca de $25 \%$ das emissões globais de $\mathrm{CO}_{2}$ seja resultante das mudanças no uso da terra, principalmente pelo desmatamento. O potencial das florestas tropicais capaz de afetar o fluxo de carbono para a atmosfera é enorme. Calcula-se que elas acumulam $20 \%$ do estoque de carbono existente no sistema terrestre do planeta, incluindo a vegetação e o solo.

A Amazônia Legal brasileira possui cerca de 5 milhões de $\mathrm{km}^{2}$, sendo que cerca 3,8 milhões de $\mathrm{km}^{2}$ são cobertos por florestas. A extensão da área coberta por florestas, que foi desmatada até o ano de 1994, está estimada em $469.978 \mathrm{~km}^{2}$ (INPE, 1996). Uma

das principais causas da devastação da floresta na Amazônia tem sido a conversão das matas nativas em pastos para a bovinocultura. As pastagens são o principal uso de terra na região amazônica. O corte e queima da biomassa vegetal é uma prática amplamente adotada na conversão de florestas em sistemas agrícolas, tais como pastagens, na Amazônia. Essa mudança no uso da terra causa transformações marcantes na biomassa da floresta e nos estoques de carbono nela contido e no solo.

Estimativas de fluxo de carbono nos trópicos, a partir de mudanças no uso da terra, são originados de modelos em que a estimativa da biomassa florestal e o seu destino em decorrência do desmatamento são peças fundamentais na confiabilidade dos resultados. No caso da Amazônia, a estimativa da biomassa florestal é bastante polêmica e ainda existe um certo grau de incerteza nas estimativas atuais. Outra fonte de incerteza está ligada aos parâmetros que irão influenciar o destino do carbono contido na biomassa. Quando a floresta é queimada espera-se que uma parte do carbono resultante da queima parcial da biomassa seja prontamente liberado e a outra remanescente seja graduamente liberada pela decomposição. Portanto, parâmetros, tais como, a eficiência de combustão, 
taxa de decomposição, formação de carvão são de grande importância para regular os modelos. No entanto a escassez de dados em relação a queima da fitomassa em florestas tropicais, já fez com que alguns autores adotassem em seus modelos valores derivados de florestas de coniferas, de regiões de clima temperado, para alguns desses parâmetros. Atualmente, ainda são poucos os trabalhos na Amazônia que estimam esses parâmetros, principalmente para os tipos florestais onde estão ocorrendo a maior parte dos desmatamentos.

Desta forma, para contribuir no avanço científico deste problema, esta pesquisa teve como objetivo estimar o estoque de carbono contido na fitomassa da Amazônia e seu potencial em liberar carbono para a atmosfera através da queima da floresta. Para atingir estes objetivos foi realizado um experimento em Ariquemes, Rondônia, para acompanhar as transformações decorrentes da queima da floresta em relação ao estoque de carbono na fitomassa e no solo. Onde, pretende-se: a) quantificar a biomassa total acima do solo antes e depois da queima; b) avaliar a eficiência de combustão e a formação de carvão e cinzas pela queima da floresta primária; e c) analisar o conteúdo de $\mathrm{C}$ nos diferentes compatimentos na biomassa aérea e no solo visando acompanhar possíveis mudanças nos seus estoques antes e depois do processo de corte e queima da floresta.

Assim, pretende-se contribuir para o entendimento das transformações da floresta pela queima e na melhoria dos cálculos para as estimativas das emissões de $\mathrm{CO}_{2}$ nos trópicos. 


\section{REVISÃO DE LITERATURA}

\subsection{As florestas tropicais e o ciclo global do carbono}

As florestas tropicais ocupam cerca de 17\% da biosfera terrestre (Melillo et al. 1993) e estão entre os ecossistemas terrestres mais importantes no balanço global do carbono (McKane et al. 1995). Estima-se que elas possuam cerca de 20 a $25 \%$ do carbono do sistema terrestre (vegetação e solo) do mundo (Brown \& Lugo, 1982; Dixon et al. 1994). Entretanto, este reservatório de carbono é prontamente afetado por pertubações na floresta provocadas pela atividade humana. Segundo Seiler \& Crutzen (1980), mais de 70\% da queima da biomassa da Terra ocorrem nos trópicos.

A queima da floresta tropical tem sido considerada como uma importante fonte de dióxido de carbono, gases traços e aerosóis para a atmosfera (Wong, 1978; Seiler \& Crutzen, 1980; Andreae et al., 1988).

O relatório elaborado pelo Painel Intergovenamental sobre Mudanças Climáticas (IPCC, 1994) estimou que, durante o período de 1980 a 1989, o desmatamento nos trópicos resultou numa emissão de $\mathrm{CO}_{2}$ anual média para a atmosfera de $1,6 \pm 1,0 \mathrm{Gt}$ (1 $\mathrm{Gt}=10^{9} \mathrm{t}$ ) de carbono. Desta maneira, as queimadas nos trópicos têm contribuído no aumento da concentração de gases na atmosfera que provocam o efeito estufa. No entanto, atualmente, grande parte das emissões de carbono para a atmosfera resultante da atividade humana é originária da queima de combustiveis fósseis. Segundo Houghton (1996), 75\% da emissões de $\mathrm{CO}_{2}$ resultam da queima de combustíveis fósseis e os outros $25 \%$ são provenientes de mudanças no uso da terra, em grande parte causada pelos desmatamentos.

Apesar do fluxo antropogênico de $\mathrm{CO}_{2}$, no ciclo global do carbono (Figura 1). seja pequeno comparado com o fluxo médio natural, ele é suficiente para pertubar o ciclo do carbono. O carbono adicional de origem antropogênica cicla entre a atmosfera, os oceanos e as biosferas marinha e terrestre. A retirada do $\mathrm{CO}_{2}$ antropogênico, particularmente pelos oceanos, ocorre lentamente, numa escala de tempo de séculos 
(IPCC, 1994). Bouwman (1990) afirmou que atualmente apenas 40\% da injeção anual de carbono na atmosfera são absorvidos pelos oceanos, resultando num acréscimo na concentração atmosférica de $0,5 \%$ ou $3,6 \mathrm{Pg}$ de carbono por ano. Assim, a adição de $\mathrm{CO}_{2}$ antropogênico tem um efeito de longa duração na concentração da atmosfera. Por exemplo, se as emissões de $\mathrm{CO}_{2}$ forem consideradas constantes, em níveis atuais, as concentrações atmosféricas poderiam continuar a aumentar pelos próximos dois séculos (IPCC, 1994).

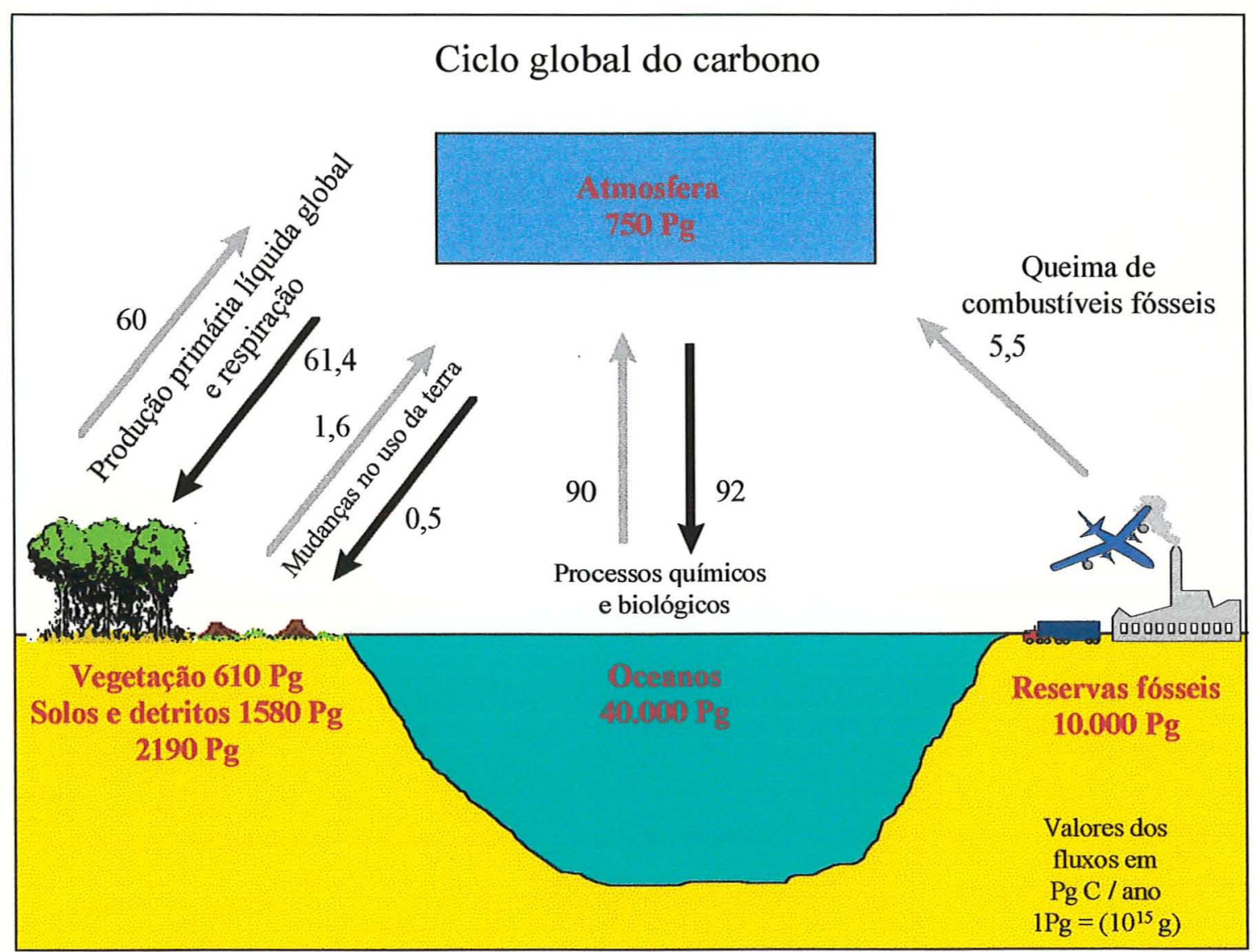

Figura 1. Esquema simplificado do ciclo global do carbono. Os valores em vermelho representam os estoques e as setas indicam os fluxos entre eles (Adaptado de IPCC, 1994). 
A concentração de $\mathrm{CO}_{2}$ na atmosfera, como consequência das atividades humanas, tem variado de $280 \mathrm{ppm}$ (base volumétrica) no período pré-industrial até 355 ppm em 1992 (IPCC, 1994). Caso a concentração de $\mathrm{CO}_{2}$ do periodo pré-industrial dobre espera-se que haja um aumento global médio na temperatura da superficie terrestre entre 1,5 a $4,5{ }^{\circ} \mathrm{C}$, o que poderá ocorrer no próximo século (Arrhenius \& Waltz, 1990; IPCC, 1994). As consequências desse aumento de temperatura podem ser bastante negativas. Alguns pesquisadores relatam como principais efeitos: o aumento do atual nivel do mar até o final do século, entre vinte centímetros a um metro e meio, provocado pelo degelo parcial das calotas polares; a queda na produção agrícola de plantas sensíveis às pequenas variações de temperatura, tal como o trigo; e as mudanças no regime de chuvas ocasionando um déficit no suprimento global de água potável (Arrhenius \& Waltz, 1990; Kirchhoff, 1992; Fearnside, 1992 a).

\subsection{A Amazônia e a emissão de carbono pelas queimadas.}

A Amazônia pela sua grande extensão de florestas, com elevado valor de fitomassa por área ocupada, possui um enorme pontecial para afetar os fluxos de carbono entre a atmosfera e a biota terrestre. As florestas podem atuar como um reservatório para estocar carbono, porém atualmente devido aos intensos desmatamentos, ela têm atuado como fonte emissora de carbono.

Para estimar a emissão de carbono gerada pelas queimadas, é necessário conhecer os tipos vegetacionais presentes na área a ser avaliada, suas respectivas biomassas, e a área afetada pelo desmatamento (Seiler \& Crutzen, 1980; Bogdonoff et al., 1985; Detwiler \& Hall, 1988; Hougthon, 1991). 


\subsubsection{Tipos de Vegetação na Amazônia}

A floresta amazônica aparentemente parece bastante uniforme, mas quando analisada em detalhe, a sua composição florística e estrutural variam muito de uma região para outra. Pires \& Prance (1985) relataram que, como o clima da Amazônia é controlado em grande parte pela vegetação, então o relevo teria papel importante sobre o tipo de vegetação. Desta forma, a vegetação poderia ser dividida em dois grande grupos: vegetação de terra firme e inundada (várzea e igapó). Ainda, Nelson (1992) afirmou que os fatores que determinam a presença de floresta versus vegetação não florestal estão ligados à disponiblididade de água no período seco. Este autor mencionou, por exemplo, que apesar da precipitação média na Amazônia ser de $2.200 \mathrm{~mm}$ por ano, existe uma faixa transversal cortanto a Amazônia, desde Boa Vista até Santarém e o baixo Xingu, onde a taxa pluviométrica anual é menor que $1.800 \mathrm{~mm}$, podendo ocorrer até cinco meses consecutivos de estresse hídrico. Nesta região, sobre os solos rasos ou arenosos podemos encontrar os campos de terra firme.

Sombroek (1992), também relacionou a capacidade efetiva do solo em estocar água aos tipos de florestas, e consequentemente ao volume de madeira estocado neles. Guillaumet (1987) afirmou que as características edáficas são determinantes básicas de quatro tipos de florestas. Estas florestas, estão associadas a solos específicos e bem definidos. assim caracterizados: floresta de terra-firme associada a latossolos argilosos; campinarana associada a latossolos arenosos; campina a podzols; e florestas pantanosas associadas a solos hidromórficos.

As formações florestais na Amazônia têm sido descritas com base no conteúdo de biomassa. estrutura e na composição florística (Veloso et al, 1974; Pires, 1978; Prance 1978; Pires \& Prance, 1985; Klinge et al., 1990)

Segundo Nelson (1992), o sistema de classificação para a vegetação da Amazônia brasileira elaborado por Pires \& Prance (1985) é um dos mais atuais. Este sistema foi adaptado de Veloso et al. (1974) e excluiu várias informações puramente geomorfológicas. O sistema de classificação adotado por Veloso et al. (1974) serviu de 
base para o mapeamento fitogeográfico da Amazônia elaborado pelo Projeto RADAMBRASIL. Este foi baseado na distribuição das formações vegetais de uma determinada região ecológica, principalmente nas feições morfológicas, subdivididas em áreas geomorfologicamente uniformes (Veloso et al., 1975).

Pires \& Prance (1985) indicaram o índice de biomassa como um modo prático de expressar as diferenças entre os tipos de vegetação. Como o peso da biomassa é difícil de ser obtido e o volume envolve a estimativa da altura das árvores que é muito variável de pessoa para pessoa, então o uso da área basal seria o melhor indicador. A área basal representa a somatória das áreas transversais dos troncos medidos à altura do peito com base em hectare. Por exemplo, florestas abertas ou de cipó geralmente estão entre 18 a $24 \mathrm{~m}^{2} \mathrm{ha}^{-1}$ e savanas abertas graminosas estarão próximas de zero.

Desta maneira, Pires \& Prance (1985) resumiram os principais tipos florestais em:

$\Rightarrow$ Formações vegetais de grande distribuição, compostas de formações de biomassa relativamente densa, que foram separados em dois grandes grupos (Florestas de terra firme e de áreas alagadas):

\section{- Florestas de terra firme}

É a formação vegetal predominante na Amazônia, ocorrendo principalmente em terrenos pouco ondulados (3-8\% de declividade), às baixas altitudes, sendo a maior parte inferior a $100 \mathrm{~m}$ e, que em nenhuma época do ano, são inundadas. Elas foram divididas em:

- Floresta densa: é a formação com maior biomassa, seu sub-bosque é ralo, e ocorre onde não há fatores limitantes tais como escassez ou excesso de água. A superficie do dossel é irregular, com altura entre 25 a $35 \mathrm{~m}$ e com poucas árvores emergentes excedendo 40 metros, apresentando, ainda, alta diversidade de espécies.

- Floresta aberta sem palmeiras: é um tipo, também muito frequente, e que cobre grande extensões na Amazônia. Sua biomassa, em termos de área basal, é geralmente um pouco acima de $20 \mathrm{~m}^{2} \mathrm{ha}^{-1}$ e possuindo árvores mais baixas do que em florestas densas. O dossel geralmente é mais plano, com poucas árvores emergentes e altura média de $25 \mathrm{~m}$. As árvores são mais distântes entre si, permitindo maior penetração 
de luz no piso florestal, assim, há uma maior tendência para o desenvolvimento de cipós e arbustos, tornando o sub-bosque mais denso.

- Floresta aberta com palmeiras: similar a anterior diferenciando pela grande presença de palmeiras no seu interior. As espécies de palmeiras de maior ocorrência são o babaçu (Orbignya phalerata). a bacaba (Oenocarpus sp.), o inajá (Maximiliana regia) e o patauá (Jessenia bataua).

- Floresta de cipó: esta é uma variação da floresta aberta, apresentando uma grande quantidade de cipós. Geralmente, ela é entremeada com florestas densas formando um mosaico complexo. A sua ocorrência é abundante ao longo da rodovia Transamazônica, de Marabá até o rio Xingu. É um tipo de vegetação característico de formações geológicas antigas. ricas em depósitos minerais tais como, ferro, alumínio, manganês, niquel e ouro.

- Floresta seca: é uma formação de transição que é geralmente encontrada na parte sudeste da Amazônia, na borda entre a Amazônia e o Brasil Central, sendo também abundantes em Roraima. Ocupam uma pequena área da Amazônia, geralmente em pequenos agrupamentos. Estas florestas apresentam uma redução parcial da folhagem do estrato arbóreo dominante em sincronia com uma estação de seca marcante. Quando a percentagem das árvores caducifólias no conjunto florestal situa-se entre $20 \%$ a $50 \%$ são chamadas de semidecíduas. Este percentual pode chegar a mais de $50 \%$, em regiões com condições climáticas mais severas, dando origem as florestas decíduas.

- Florestas de montanha: estas formações diferenciam-se das outras por ocorrerem em regiões de elevada altitude e o tipo de solo rochoso. São características de regiões montanhosas do extremo norte da Amazônia, nos limites entre a Venezuela e as Guianas. A vegetação tende a tornar-se mais esparsa quanto maior o grau de declividade do terreno, por causa da reduzida capacidade de retenção de água destes solos. Desta maneira, geralmente, o aumento da altitude está relacionado com a diminuição da biomassa. 
- Florestas inundadas (várzeas e igapós).

Estas compõem o segundo grande grupo de formações com biomassa relativamente densa.

Regionalmente o termo várzea e igapó são aplicados a tipos de solo e vegetação, denotando excesso de umidade ou condição de alagamento. A vegetação de várzea é inundada por rios de águas barrentas, com grande carga de sedimentos, tais como o rio Amazonas e o Madeira, e a vegetação de igapó são inundadas por rios de águas claras, ou escuras, com pouco sedimentos em suspensão. Estas podem ser divididas em :

- Florestas de várzea do Alto Amazonas: estas florestas são contínuas, ou entremeadas por lagos, e não estão associadas com áreas de capinzal robusto (canarana). As espécies arbóreas de várzea tendem a ter a madeira mais macia do que aquelas de terra firme. A presença de árvores com sapopemas é comum nestas áreas. Algumas das espécies mais freqüentes são: a seringueira (Hevea brasiliensis), a andiroba (Carapa guianensis) e a ucuúba (Virola sp.).

- Florestas de várzea do baixo Amazonas: estas são caracterizadas por estreitas extensões de florestas sobre a margem mais alta dos rios principais e seus tributários. Por trás das florestas estão os capinzais, conhecidos como canarana. As espécies arbóreas mais comuns são a munguba (Bombax munguba), o açacu (Hura crepitans), o pau mulato (Calycophyllum) e a embaúba (Cecropia paraensis).

- Floresta de várzea estuarina: as várzeas estuarinas possuem solos argilosos formados por águas barrentas, apresentam grande presença de palmeiras e seu alagamento é causado mais pelo movimento das marés do que pelo ciclo anual dos rios. Algumas florestas de várzea estuarina possuem uma biomassa extremamente alta, geralmente sujeitas a exploração madeireira. As palmeiras mais abundantes são o murumurú (Astrocaryum murumuru), o jupati (Raphia taedigera), o açaí (Euterpe oleracea) e o inajá (Maximiliana regia).

- Floresta de igapó em areias brancas: estas florestas ficam ao longo de certas partes de rios de águas claras, tais como, o Tapajós e o Arapiuns. Suas margens de areias brancas são cobertas por árvores. $\mathrm{Na}$ estação seca as árvores crescem nessas areias e 
durante a inundação seus troncos ficam imersos na água. Entre os membros mais comuns das árvores de igapós estão o tachi (Triplaris surinamensis), a piranheira (Piranhea trifoliata) e a copaiba (Copaifera martii).

$\Rightarrow \mathrm{O}$ segundo grupo de vegetação que cobre uma de grande extensão da Amazônia, porém com baixa biomassa, é representado por tipos não florestais, tais como as savanas e as campinas. Este grupo foi dividido por Pires \& Prance (1985) em:

- Savanas de terra firme: as formações de savanas de terra firme variam desde áreas abertas de campos sem vegetação lenhosa, dominadas por gramíneas, com área basal de 0 a $2 \mathrm{~m}^{2}$ por hectare até tipos de savanas mais densas com grande presença de plantas lenhosas que, geralmente, não excedem a $5 \mathrm{~m}^{2}$ por hectare.

- Savanas de Litoral: ocorrem na parte costeira de Marajó e em Bragança no Pará e são caracterizadas por uma cobertura rasteira de gramineas em solo rasos. Nestes locais a presença de lagos é frequente. A gramínea mais comum é a Paratheria prostata.

- Campos de Roraima: embora parecido com as savanas de terra firme, possuem algumas diferenças marcantes. Elas ocorrem em regiões com numerosos locais alagados, formando lagos ou meandros inundados, onde há uma grande concentração de buritis (Mauritia flexuosa). Esses agrupamentos de palmeiras com aspecto de linhas na paisagem são uma caraterística que não ocorrem nas savanas da Amazônia nem em cerrados do Planalto Central. Na classificação do RADAMBRASIL, elas são chamadas de savanas estépicas.

- Campos rupestres: são formações abertas em rochas, geralmente confudidas com savanas abertas, porém bastante diferentes fisionomicamente e floristicamente. $\mathrm{Na}$ Amazônia elas podem ser encontradas na Serra do Cachimbo e na Serra dos Carajás, no Pará, sobre depósitos de ferro, localmente chamada de vegetação de canga.

- Campos de várzeas: sua ocorrência é comum na região aluvional entre os rios Negro e Xingu e especialmente entre o rio Madeira e a cidade de Monte Alegre. Localizam-se próximas às florestas de várzeas, na parte inferior da zona de inundação. Estes campos são cobertos por várias gramíneas robustas, geralmente chamadas de 
canarana (falsa cana), sendo que algumas destas, durante a cheia, são flutuantes, tais como, a Eichornia azurea, Pistia stratiotes e a Ceratopteris pteridioides. Também estão presentes ervas lenhosas e pequenos cipós que podem tornarem-se invasoras de pastos degradados.

- Campinas amazônicas (formações oligotróficas em areias brancas): estas formações são também chamadas de caatinga, campinarana, chavascal, charravascal, para denominar a mesma vegetação ou pequenas variações entre elas. $O$ nome caatinga deveria ser evitado pois poderia confundir com a vegetação de regiões áridas do Nordeste brasileiro. As campinas amazônicas variam desde tipos vegetacionais completamente abertos até densos. Sua separação em associações específicas é dificil. porque há, nestas regiões, uma completa continuidade do tipo aberto até formações florestais fechadas. Estas formações estão sujeitas a vários fatores de estresse. Entre esses fatores estão os solos que são pobres em nutrientes e a sazonalidade causada pelo alagamento do solo, que são rasos, impedindo o desenvolvimento das raízes durante o período chuvoso, e o forte estresse hídrico, durante o "verão", causado pela excessiva porosidade de suas areias.

$\Rightarrow$ Um outro grupo considerado a parte por Pires \& Prance (1985) são as vegetações que cobrem áreas restritas, mas que são bastante distintas das outras. Entre estas são citadas:

- Florestas de mangue (manguezais): ocupam uma pequena área na Amazônia brasileira na estrita faixa do litoral que está sujeita à inundação por água salina. Sua vegetação é pobre em número de espécies e bastante uniforme. As principais espécies que ocorrem em manguezais brasileiros são o mangue vermelho (Rhizophera mangle), o mangue branco (Avicennia nitida) e a Laguncularia racemosa.

- Pirizal: é uma formação restrita às pequenas áreas. Ocorrem em lagos rasos ou em áreas com água empoçada ou estagnada. As plantas mais frequentes são a Cyperus giganteus e a Thalia geniculada, assim como plantas aquáticas ou com folhas flutuantes. 
Nestes locais, também, é comum encontrar palmeiras crescendo ao redor das margens. Essas formações são comuns no Amapá, em áreas ao longo da costa.

- Buritizal: esta formação é, na sua maior parte. composta por buritis (Mauritia flexuosa). Ela ocorre em várias partes do estuário do Amazonas.

- Vegetação de restinga: desenvolvem-se em dunas de areia, possuem aspecto xeromórfico e assemelha-se fisionomicamente às campinas amazônicas.

O conhecimento da cobertura vegetal é um peça básica na estimativas da biomassa na Região Amazônica. Os tipos florestais que cobrem a Amazônia são bastante diversificados. Fearnside (1992 a) estimando a biomassa para Amazônia Legal considerou como floresta, 19 tipos de vegetação. Porém algumas estimativas da biomassa florestal na Amazônia têm considerado apenas as formações abrangidas pelas florestas densas (Fearnside, 1989; Brown \& Lugo, 1992). Estes diferentes critérios metodológicos podem levar a resultados discordantes, em relação ao estoque de biomassa presente na Amazônia.

\subsubsection{Fitomassa na Amazônia}

A estimativa da fitomassa para Amazônia tem gerado extensos debates no meio cientifico (Brown \& Lugo, 1984, 1992; Fearnside, 1985, 1986, 1992 b, 1993; Lugo \& Brown, 1986; Brown et al., 1989). Apesar deste grande esforço no sentido de aprimorar as estimativas para esta imensa região, algumas incertezas em relação à confiabilidade dessas estimativas ainda tem sido mencionadas por Brown, et al. (1995). A estimativas mais recentes para a biomassa total da floresta na Amazônia a partir de inventários em escala regional variam de $227 \mathrm{tha}^{-1}$ a $464 \mathrm{t} \mathrm{ha}^{-1}$ (Tabela 1). 
Tabela 1. Estimativas mais recentes para biomassa florestal $\left(\mathrm{t} \mathrm{ha}^{-1}\right)$ na Amazônia a partir de levantamentos em escala regional.

\begin{tabular}{clll}
\hline Biomassa Total & Banco de dados & Tipo de floresta & Fonte \\
\hline $227^{(1)}$ & RADAMBRASIL & apenas densa & Brown \& Lugo, 1992 \\
$298^{(1)}$ & FAO & apenas densa & Brown \& Lugo, 1992 \\
$272^{(2)}$ & RADAMBRASIL & inclui todos & Fearnside, 1992b \\
$320^{(2)}$ & RADAMBRASIL & apenas densa & Fearnside, 1992b \\
$372^{(2)}$ & RADAMBRASIL/FAO ${ }^{(3)}$ & inclui todos & Fearnside, 1992 a \\
$394^{(2)}$ & RADAMBRASIL/FAO & inclui todos & Fearnside, 1992 a \\
$232^{(1)}$ & RADAMBRASIL & densa e aberta & Bohrer \& Campos, \\
$434^{(2)}$ & RADAMBRASIL/FAO & inclui todos & Fearnside, 1996 \\
$464^{(2)}$ & RADAMBRASIL/FAO & inclui todos & Fearnside, 1996 \\
\hline
\end{tabular}

Nota: (1) Apenas para a biomassa acima do solo

(2) Incluindo a biomassa acima solo e abaixo do solo .

(3) Estimativa para a biomassa da floresta sendo desmatada em 1990 na Amazônia Legal

\subsubsection{Métodos empregados para a estimar a fitomassa na Amazônia}

Os métodos mais empregados para estimar a fitomassa na Amazônia são: o direto ou de colheita destrutivo e o indireto que é calculado via análise de regressão, baseado nas relações alométricas das árvores. Independentemente do método aplicado deve-se ter em mente que, em termos de carbono como fonte potencial para o efeito estufa, todo material de origem vegetal presente na floresta deve ser quantificado. Portanto, a biomassa total da floresta deve-se referir não apenas às árvores, mas a todos os compartimentos presentes nela, tais como cipós, arbustos, palmeiras, raízes e material vegetal morto.

O método direto consiste na pesagem completa da biomassa contida nas parcelas amostrais e depois sua extrapolação em hectare(ha). Assim, é necessário que a biomassa 
da floresta seja reduzida em pequenas cargas capazes de serem pesadas manualmente através de balanças (Klinge et al. 1975; Klinge \& Herrera, 1983; Fearnside et al., 1993). Este processo é bastante trabalhoso e requer um gasto de tempo muito grande em relação a área a ser amostrada quando comparado com métodos indiretos.

O método direto para estimar a biomassa florestal na Amazônia tem sido duramente criticado por Brown \& Lugo (1992). Suas principais críticas são: a quantidade de dados disponiveis provindos de pequenas parcelas, que são escassos para a dimensão da Amazônia. e a tendenciosidade na escolha das áreas de estudo pelos pesquisadores, por selecionarem áreas florestais com biomassa maior do que a média geral para a região. No entanto. Fearnside (1992b) rebate este último argumento atribuindo os altos valores de biomassa à alta variabilidade na biomassa florestal juntamente com o potencial de erro para pequenas parcelas.

Brown, et al. (1995) observaram que a alta variabilidade das médias obtidas em parcelas pequenas são explicadas pela ausência de árvores de grande porte na maioria delas. Consequentemente, isto produzirá um valor médio abaixo da média global. No entanto, as poucas unidades com grandes árvores tenderão a aumentar grandemente a biomassa.

Porém, as medições diretas pela pesagem da biomassa são necessárias para estimar outros componentes da floresta que não estão disponíveis em levantamentos florestais para volume de madeira comercial, através de medidas indiretas. Estas, também são capazes de gerar informações úteis na quantificação das transferências de carbono pelas queimadas, tais como eficiência de combustão, formação de carvão, e o estoque de resíduos não queimados sujeito à decomposição.

O método indireto, também bastante empregado na Amazônia, baseia-se na relação alométrica entre o diâmetro à altura do peito (DAP) e a altura das árvores. Neste método, a estimativa da biomassa florestal é feita via análise de regressão, onde são testadas várias equações de ajuste para obter um modelo ideal que possa ser aplicado às árvores. Estes modelos são calibrados pela pesagem direta, a partir de uma subamostragem das árvores (Jordan \& Uhl, 1978; Higuchi \& Carvalho, 1994; Brown. et 
al., 1995). O método indireto é largamente adotado no setor florestal para avaliar o volume de madeira de valor econômico.

Há um concenso entre os pesquisadores de que a utilização de banco de dados de inventários florestais, com alta representatividade regional, tais como os realizados pelo Projeto RADAMBRASIL na década de setenta e os da FAO (Organização das Nações Unidas para Agricultura e Alimentação) durante as décadas de cinquenta e sessenta, é a maneira mais adequada para obter estimativas mais precisas para o estoque de biomassa na Amazônia (Brown et al., 1989; Fearnside, 1992b; Boher \& Campos, 1993). Os inventários feitos pelo RADAMBRASIL e FAO tiveram por objetivo avaliar o volume de madeira comecializável na Amazônia. Desta maneira, incluiram apenas árvores com diâmetro à altura do peito (DAP) igual ou acima de $31,8 \mathrm{~cm}$, no caso do RADAMBRASIL, e $25 \mathrm{~cm}$ de DAP no levantamento da FAO. Assim, estimativas utilizando-se dados desses inventários necessitam de vários fatores de ajuste para que possam ser expandidos em termos de biomassa total. Uma parte das incertezas relacionadas às diferentes estimativas de biomassa na Amazônia está na exclusão de alguns dos componentes da biomassa. Desta maneira, Fearnside (1992b) cita vários fatores de ajuste a serem adotados nas estimativas de Brown \& Lugo (1992) baseadas nos levantamentos feitos pelo RADAMBRASIL e FAO.

Um outro método indireto que merece atenção devido a sua comodidade e precisão na avaliação rápida do volume de troncos, em áreas de floresta derrubada, é o da amostragem por intersecção de linhas, também conhecido como LIS (line intersect sampling). Este método foi desenvolvido primeiramente para florestas de coniferas em regiões de clima temperado, para estimar o volume de resíduos vegetais, acima de um certo limite de tamanho (Warren \& Olsen, 1964; de Vries, 1974; Kaiser, 1983). Esta técnica possui a vantagem de produzir estimativas de volume com boa precisão a um baixo custo quando comparado com métodos convencionais, porém requeria um teste preliminar para a tendenciosidade na orientação das toras (Warren \& Olsen, 1964). Posteriormente, Van Wager (1968) desenvolveu esta técnica para ser aplicável na estimativa de volume de madeira sobre o solo em qualquer forma, não requerendo testes 
preliminares para erros de tendenciosidade na orientação. Atualmente este método vem sendo utilizado para estimar o volume de biomassa em áreas com a prática de corte e queima na Amazônia para avaliar as transformações da biomassa florestal decorrentes da queima (Kauffman et al., 1988; Kauffman et al.,1995; Fearnside et al., 1993).

O emprego de técnicas mais sofisticadas, tais como, o sensoriamento remoto utilizando o NDVI (normalized difference vegetation index) a partir de dados do Landsat TM, mensurações aéreas a laser e dados de radar usando imagens de SAR (synthetic aperture radar) também têm sido aplicado na quantificação da biomassa aérea da floresta (Nelson et al., 1988; Sader et al., 1989). Estes métodos são considerados indiretos e empregam regressões para ajustar uma equação que possa melhor predizer a biomassa a partir dos sinais emitidos pelos sensores. Porém, na Amazônia estes métodos ainda não têm sido empregados. Problemas técnicos em relação ao emprego destes métodos em florestas tropicais tem impossibilitado que o sensoriamento remoto seja usado sem que haja um grande grau de incerteza em relação as suas estimativas. Honzák et al.(1996) mencionaram que algumas técnicas de sensoriamento remoto podem levar a resultados inconclusivos porque apenas a reflectância espectral das camadas mais superiores do dossel é detectada pelos sensores. Outra dificuldade relatada por Brown et al. (1989) no emprego do sensoriamento remoto seria o dificil acesso nas checagem de campo para calibrar as medições.

\subsubsection{Extensão do desmatamento na Amazônia Legal}

Até a década de 60 muito pouco da cobertura florestal na Amazônia havia sido alterada. A partir dos anos 70 , quando foram inplementados vários programas de desenvolvimento, iniciou-se o desmatamento de forma acelerada, prosseguindo nas décadas seguintes (Leopoldo et al., 1987, Fearnside, 1992b). As estimativas iniciais para a extensão do desmatamento na Amazônia eram muito grosseiras, e baseavam-se em comparações de inventários florestais através do tempo (Houghton, 1990). Somente a partir dos anos 80 , com o emprego de técnicas de sensoreamento remoto, através da 
interpretação de imagens de satélite, é que as estimativas tornaram-se mais confiáveis. No entanto, as dificuldades de checagens em campo e diferentes interpretações dos dados obtidos resultaram em estimativas divergentes entre pesquisadores.

Uma das primeiras estimativas para a Amazônia Legal interpretando imagens do satélite Landsat, utilizando o sensor MSS (Multispectral Scanner System, com resolução de $80 \mathrm{~m}$ ) foi feita por Tardin et al. (1980). Eles estimaram que cerca de $77.172 \mathrm{~km}^{2}$ ( 1,6\%) da Amazônia Legal, tinham sido desmatados até 1978. A dificuldade em distinguir florestas secundárias antigas de florestas primárias fez com que esta estimativa fosse considerada subestimada (Fearnside 1982, 1986, 1993). Outra estimativa, também utilizando o Landsat MSS, feita pelo IBDF (1983) ${ }^{1}$, citado por Martinelli (1993), avaliou o desmatamento para os estados da Amazônia Legal, excluindo o Amapá e o Amazonas. Mahar (1989) com base nestes dados, extrapolou uma área de $125.107 \mathrm{~km}^{2}$ desmatada para toda Amazônia para o ano de 1980. Apesar dos problemas relacionados com a interpretação dos dados, estas estimativas mostravam um forte tendência exponecial em relação a taxa de desmatamento para alguns estados, principalmente Rondônia, Mato Grosso e Acre. Com base nessa observação Fearnside (1982) concluiu que, caso fosse mantida essa tendência exponencial para Amazônia Legal, ela estaria inteiramente desmatada em 1991. Fato que não ocorreu provavelmente porque as taxas de desmatamento são muito variáveis entre os estados que a compõem.

A partir do lançamento, em 1984, do satélite Landsat 5 que carrega o sensor TM (Thematic Map) com uma resolução de $30 \mathrm{~m}$, foi possível a obtenção de estimativas mais precisas para Amazônia. Tardin \& Cunha (1990)², citado por Martinelli et al. (1993). com base nas imagens obtidas pelo Landsat TM, avaliaram para o período de 1978 a 1988 uma área desmatada de 250 mil km² e uma taxa anual de 17 mil km². Fearnside et al. (1990) reavaliando esta estimativa, reanalisando os dados de 1978, encontraram uma área desmatada de $362 \mathrm{mil} \mathrm{km}^{2}$ para o ano de 1988 e uma taxa anual de desmatamento de

\footnotetext{
'IBDF. Desenvolvimento florestal no Brasil. Brasília: IBDF/PNUD/FAO. BRA-82-008., 1983.

2 Tardin. A.T ; Cunha, F.P. Evaluation of deforest in the Legal Amazon using Landsat-TN images, São José dos Campos: Instituto Nacional de Pesquisas Espaciais, 1990. 23p.
} 
$21,2 \mathrm{~km}^{2}$ para o período de 1978 a 1989. A área desmatada encontrada para 1978, por esses autores. foi de $54 \mathrm{mil} \mathrm{km}^{2}$ bem menor do que os 77 mil $\mathrm{km}^{2}$ encontrados anteriormente por Tardin et al. (1980). Isto foi justificado pela inclusão de antigos desmatamentos e de áreas de cerrado desmatadas.

Fearnside (1993), em uma nova revisão das taxas de desmatamento para o período de 1978 a 1991 incluindo áreas de florestas inundadas por represas de hidrelétricas. estimou que a Amazônia tinha perdido até 1991 uma área de floresta de 400 mil de $\mathrm{km}^{2}$, ou seja $10,5 \%$ das suas florestas originais. Nesta revisão também verifica-se um declínio na taxa anual de desmatamento. Durante o período de 1978 a 1988, a taxa média anual de desmatamento foi de $22 \mathrm{mil} \mathrm{\textrm {km } ^ { 2 }}$. Em 1989, esta taxa foi de 19 mil $\mathrm{km}^{2}$, sendo reduzida novamente para $13,8 \mathrm{mil} \mathrm{km}^{2}$, no ano de 1990 . Esta tendência também foi verificada em 1991 que apresentou uma área desmatada de $11,1 \mathrm{mil} \mathrm{\textrm {km } ^ { 2 }}$. Fearnside (1993) atribuiu ao declínio nas taxas de desmatamento, a recessão econômica durante este período.

Outras estimativas a partir do satélite meteorológico NOAA-9 utilizando o sensor AVHRR (Advanced Very High Resolution Radiometer) com uma resolução de 1,1 km, têm gerado valores de desmatamento muito mais altos do que os de Landsat. Myers $(1989,1991)$ estimaram uma taxa anual para 1988 de 50 mil $\mathrm{km}^{2}$. Setzer \& Pereira

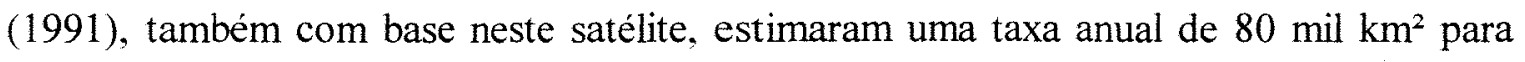
1987. Vários problemas metodológicos são apontados por Fearnside (1990, 1992a) na utilização da banda infra-vermelha termal do AVHRR, adotada em ambos estudos, para estimar áreas desmatadas a partir de queimadas na Amazônia. No entanto, estas estimativas têm sido usadas em vários cálculos recentes no balanço global de carbono, feitos pelo Instituto de Recursos Mundiais (WRI) e pelo Painel Intergovernamental sobre Mudanças Climáticas (IPCC) (Fearnside, 1992b. 1993).

Recentemente, resultados de um levantamento das áreas desflorestadas feito pelo Instituto Nacional de Pesquisas Espaciais mostraram que as taxas de desmatamento na Amazônia Legal voltaram a crescer a partir de 1991. Entre o periodo de 1991 a 1992 houve um aumento anual de $2.656 \mathrm{mil} \mathrm{km}^{2}$ em relação ao periodo anterior de $1990 \mathrm{a}$ 
1991 (estimado em 11,1 $\mathrm{km}^{2}$ ). Durante o periodo de 1992 a 1994, a taxa de desflorestamento aumentou cerca de $0,4 \%$ em relação ao período anterior, sendo desmatadas anualmente uma área de floresta correspondente a 14,9 mil $\mathrm{km}^{2}$ (INPE, 1996).

\subsubsection{Emissões de $\mathrm{CO}_{2}$ pelo desmatamento na Amazônia}

Fearnside (1996) relatou duas maneiras para calcular as emissões de $\mathrm{CO}_{2}$ liberadas pelo desmatamento. A primeira, mencionada como emissões líquidas. comprometidas. expressa a contribuição final da transformação da floresta original em uma nova paisagem, a partir da comparação dos diversos usos da terra que resultará numa condição de equilíbrio através da projeção de tendências atuais. Neste cálculo inclui-se as emissões pela decomposição ou requeima dos troncos remanescentes da floresta original, e a reabsorção do carbono do pelo crescimento das floresta secundárias em locais abandonados depois do uso agrícola.

A outra forma de calcular enfoca o balanço anual da liberação e a retirada de gases que contribuem para o efeito estufa em um determinado ano, também chamada de balanço anual líquido de emissões. Este balanço representa uma medida instantânea dos fluxos de gases do efeito estufa, dos quais o $\mathrm{CO}_{2}$ é um deles.

Estimativas do balanço anual líquido de carbono são importantes para atribuir a responsabilidade no aquecimento global entre as nações. Na Conferência da Nações Unidas sobre Meio Ambiente e Desenvolvimento, realizada no Rio de Janeiro em 1992 (ECO-92), mais de 150 paises assinaram um acordo no Painel sobre Mundanças Climáticas que exige de cada pais um inventário das fontes, sumidouros e reservatórios de gases de efeito estufa (Fearnside, 1996; Schroeder \& Winjum, 1995).

Fearnside (1992a) estimou a contribuição do desmatamento da Amazônia na emissão de $\mathrm{CO}_{2}$, entre 281 e 282 milhões de toneladas de carbono, na forma de emissões líquidas comprometidas, para o ano de 1990, considerando o desmatamento em áreas de florestas e cerrado. 
Em estudo mais recente, Fearnside (1996) calculou o balanço anual de gases de efeito estufa provenientes da mudança do uso da terra na região amazônica, para o ano de 1990. O valor para emissão liquida de $\mathrm{CO}_{2}$ totalizou entre 1245 e $1248 \mathrm{Tg}\left(10^{12} \mathrm{~g}\right)$ ou 340 e $341 \mathrm{Tg}$ de carbono. Considerado-se também os efeitos de outros gases traço $\left(\mathrm{CH}_{4}\right.$, $\mathrm{CO}$, e $\mathrm{N}_{2} \mathrm{O}$ ), através do potencial de aquecimento global adotado pelo IPCC para um horizonte de 100 anos, este valor aumentaria para 358 a $367 \mathrm{Tg}$ de toneladas de carbono na forma equivalente ao $\mathrm{CO}_{2}$. Ainda, este autor estimou que a emissão de $\mathrm{CO}_{2}$, somente para o desmatamento na Amazônia Legal, em 1990, representou 5\% do total global das emissões de combustíveis fósseis e de desmatamento.

Outras estimativas feitas na Amazônia têm considerado apenas emissões pela queima da floresta ou considerando a conversão da floresta em apenas um tipo de paisagem, geralmente pastagens. Setzer \& Pereira (1991) estimaram em $1700 \mathrm{Tg}$ de $\mathrm{CO}_{2}$ ou 520 milhões de toneladas de carbono, na emissão pelas queimadas em 1987 na Amazônia. Este valor é bastante elevado e não representa um balanço líquido, ou seja, não inclui nos cálculos a remoção de $\mathrm{CO}_{2}$ pelo crescimento de vegetação secundária em áreas desmatadas. Araújo (1995) utilizando uma taxa de desmatamento de 3,2 milhões de hectares para o ano de 1987, encontrou um valor bem mais baixo de $220 \mathrm{Tg}$ de $\mathrm{CO}_{2}$ emitido por queimadas. Apesar de comparar seus dados com os de Setzer \& Pereira (1991) a autora não explica o motivo desta discrepância. Provavelmente a metodologia para os cálculos e os diferentes fatores para eficiência de combustão e biomassa da vegetação podem ter contribuído para isso.

Esses valores tão discrepantes, em parte pela metodologia adotada, indicam a necessidade de melhorar os parâmetros que influenciam nos modelos de emissão de gases de efeito estufa, tais como biomassa da vegetação, eficiência de combustão, taxa de decomposição da biomassa não queimada em áreas desmatadas e formação de carvão. 


\subsubsection{A prática de corte e queima na Amazônia}

A derrubada e a queima da floresta são práticas amplamente adotadas nos trópicos como uma forma econômica e simples de preparo de área tanto no sistema de agricultura intinerante como nos sistemas de agricultura intensiva (Dantas \& Matos, 1981; Smyth \& Bastos, 1984; Martins et al., 1990).

O proceso de derrubada consiste inicialmente no corte do sub-bosque da floresta para facilitar o acesso entre as árvores. Este processo é geralmente denominado como "brocagem" ou "roçagem" e é feito geralmente utilizando-se facões (Martins, 1987). Após a roçagem, as árvores de menor porte são parcialmente cortadas, permanecendo em pé, para que posteriormente as árvores maiores as derrubem. Este processo é favorecido pela quantidade de cipós entrelaçados entres as copas das árvores que ajudam a promover um efeito "dominó" na queda das árvores (Higuchi \& Carvalho, 1994; Araújo, 1995). Os cortes das árvores feitos por motosserra tendem a ser mais rentes ao chão do que o machado, deixando menor quantidade de fitomassa em forma de tocos (Fearnside et al. ${ }^{1}$ ). Geralmente, árvores de grande valor ou protegidas por lei, tal como a castanheira são deixadas em pé (Kauffman et al., 1995). A derrubada é realizada pelos colonos, na Amazônia no fim da estação chuvosa ou início da estação seca. Na região de Rondônia, ela é realizada geralmente durante os meses de maio a junho, aguardando-se cerca de 2 meses para praticar a queima. Esta espera tem por objetivo a redução do conteúdo de água no tecido vegetal a fim de possibilitar uma melhor eficiência na combustão.

A queima da floresta na Amazônia é um evento único durante o ano, e geralmente depende de condições climáticas favoráveis num curto período de tempo. Ela é feita pelos colonos, na região de Rondônia, nos meses mais secos entre julho a novembro. A queimada geralmente é feita na hora mais quente do dia, ateando-se o fogo nas bordas da

\footnotetext{
${ }^{1}$ Feanside, P.M.; Graça, P.M.L.A.; Keller, M.; Leal Filho: N.; Robinson. J.M.; Rodrigues, F.J.A. Métodos para avaliação de transformações de biomassa na queima da floresta tropical (em elaboração).
} 
área derrubada para que as chamas se encontrem no meio do terreno e maximize o efeito da queima (Kauffman et al., 1995).

\section{a) Fatores que influenciam a qualidade da queimada e sua avaliação}

A queima da biomassa da floresta é um fenônemo que depende de vários fatores intrínsecos e extrínsecos ao material combustível exposto ao fogo. Jordan (1985) indicou como principais fatores na qualidade da queima, o grau de umidade, a densidade específica e o diâmetro dos troncos, a configuração espacial da carga combustível e fatores climáticos. Entre os fatores climáticos podemos citar as condições ambientais do local durante o processo da queima, tais como temperatura do ar, a velocidade dos ventos e a umidade relativa do ar. A configuração espacial da carga combustível sobre o terreno é outro fator extrínsico que pode afetar a variabilidade da queima. As derrubadas formam um mosaico de áreas mais carregadas com combustível formada pelas copas e troncos e outras menos carregadas formada só pelos troncos (Fearnside et $\mathrm{al}^{1}$.). Estas áreas mais carregadas tedem a queimar mais completamente do que aquelas somente dominadas por troncos. Entre os fatores intrínsecos do material combustivel, que também irão influenciar na queimada, estão o conteúdo de água na madeira viva, a velocidade de secagem, densidade e a composição química da madeira. A umidade da madeira antes da queima está geralmente associada ao diâmetro da peça do material combustível. Assim, espera-se que diâmetros maiores levem mais tempo para reduzir o teor de água durante o período de secagem que antecede a queima do que peças com diâmetros menores (Kauffman et al., 1988). Por exemplo, os troncos de árvores teriam um teor de umidade maior do que os galhos finos na hora da queima. Kauffman et al. (1988) afirmaram, também, que o conteúdo químico da vegetação têm um importante papel no comportamento da queimada e que o poder calorífico do material combustível afetará a

\footnotetext{
Feanside, P.M.; Graça, P.M.L.A.; Keller, M.; Leal Filho; N.; Robinson, J.M.; Rodrigues, F.J.A. Métodos para avaliação de transformações de biomassa na queima da floresta tropical (em elaboração).
} 
intensidade do fogo, enquanto componentes no conteúdo das cinzas podem agir retardando as chamas.

Outro fator relacionado às espécies que contribui na complexidade espacial da distribuição das cargas combustíveis é o fato de algumas espécies formarem aglomerados. Por exemplo, palmeiras tais como, o babaçu (Orbignya speciosa) ou o açaí (Euterpe oleracea) tendem a aglomerar-se, formando pontos de dificil combustão, uma vez que estas espécies são resistentes ao fogo (Fearnside, 1990; Uhl \& Kauffman, 1990).

Como foi demonstrado anteriormente, o resultado de uma queimada pode ser bastante variável. Fearnside et al. (1993) adotaram um sistema de avaliação visual grosseira, para classificar a qualidade da queimada em áreas de floresta derrubada. próxima a Manaus. Este sistema consiste em classificar a qualidade da queima em cinco categorias: "excelente" quando queima no mímino alguns troncos até às cinzas; "boa" quando queima cipós e galhos grossos; "média" quando folhas e galhos finos são queimados; "pobre" quando apenas as folhas são queimadas; e "ruim" quando não queima nem mesmo as folhas secas sobre o solo. Este mesmo estudo evidenciou uma grande variabilidade na qualidade da queima. Do total de 200 pontos amostrais, 67\% foi classificado como excelente ou boa e 33\% tiveram a queimada classificada como média. pobre ou nula.

\section{b) Transformações da biomassa aérea florestal pela queima}

A queima da biomassa é uma das fontes de gases de efeito estufa que tem menos fundamento em medidas de campo, nos cálculos de modelos de emissões globais de $\mathrm{CO}_{2}$ (Fearnside, 1991). A eficiência de combustão e a formação de carvão são fatores importantes no destino do carbono após a queima da fitomassa, porque controlam a quantidade de carbono que será liberada pela combustão e a que ocorrerá pela decomposição. Quando a floresta é cortada e queimada, para fins agrícolas, uma parte da biomassa original é liberada imediatamente para a atmosfera como dióxido de carbono, outra parte permanecerá como carvão, e a parte remanescente que não foi queimada irá 
decompor-se lentamente e liberar $\mathrm{CO}_{2}$ por vários anos (Seiler \& Crutzen 1980; Houghton, 1990).

Wong (1978) sugeriu que fosse adotado para os trópicos o valor de $75 \%$ de eficiência da combustão, nos cálculos de emissão de dióxido de carbono para a atmosfera. Entretanto, este valor foi estimado a partir de dados de uma queimada experimental de floresta secundária de Pseudotsuga taxifolia (Douglas fir), em zonas temperadas e boreais. Valores bem mais baixos que este têm sido encontrado atualmente em áreas de queimada na Amazônia. Fearnside et al. (1993) que foram pioneiros neste tipo de estudo, encontraram um valor $27,6 \%$ para eficiência de combustão, próximo de Manaus, em termos de carbono. Recentemente, outros estudos na região Amazônica tem apontado valores de eficiência de combustão entre 22 e $52 \%$ (Fearnside et al., 1993; Fearnside et al.' ; Kauffman et al.,1995; Araújo, 1995), em termos de carbono liberado para a atmosfera na forma de gases. Porém essas estimativas ainda são insuficientes para grande extensão e variedade de florestas que existem na Amazônia. Principalmente para florestas nas áreas atingidas pelos desmatamentos mais recentes, tais como as regiões limitrofes da parte sudeste da Bacia Amazônica (Fearnside, 1990).

A eficiência de combustão por ser importante no controle da quantidade liberada de carbono pela queima da biomassa, faz com que a compartimentalização dos estoques de biomassa em classes de diâmetro e tipo de material de vegetal seja de grande valia. Já que os teores de carbono e, principalmente, de água estão concentrados diferenciadamente nestes compartimentos.

Outro parâmetro muito pouco estudado nos trópicos é a formação de carvão resultante da queima da fitomassa florestal. Seiler \& Crutzen (1980) sugeriram um valor de $20-30 \%$ do total da biomassa acima do solo após a queima para estimar a formação de carvão em florestas tropicais para para ser usado em modelos de carbono global. Esse valor corresponde a $15-23 \%$ do carbono da biomassa acima do solo antes da queima.

\footnotetext{
${ }^{1}$ Fearnside, P.M.; Graça, P.M.L.A; Leal Filho. N.; Rodrigues, F.J.A.; Robinson, J.M. Tropical forest burning in Brazilian Amazonia: measurements of biomass, combustion efficiency and charcoal formation at Altamira, Pará (em elaboração).
} 
Assim, indicando que esse compartimento contribui significativamente para formação de reservatório de longa duração de carbono. Porém. esses dados foram extrapolados a partir de uma avaliação qualitativa da queima de uma floresta de Pinus ponderosa nos Estados Unidos. Num trabalho mais recente Crutzen \& Andreae (1990) usaram um valor de $5 \%$ para a formação de carvão baseado em dados preliminares do estudo de Fearnside et al. (1993) que era de $3,6 \%$ e do valor de 5,4\% derivado de um estudo de fogo controlado em floresta de conífera na Flórida. Fearnside et al. (1993) substituiram o valor de 3,6\% preliminarmente encontrado pelo valor de 2,7\% (após assumir um valor mais alto para o conteúdo de carbono no carvão) para estimar a porcentagem de carbono na biomassa acima do solo antes da queima que é convertida em carvão, em uma floresta primária próxima a Manaus.

A escassez de dados quantitativos a respeito da formação de carvão para queimadas em florestas tropicais faz com que seus resultados sejam extrapolados por estimativas em floresta de coniferas, indicando a necessidade urgente de se ampliar as medições nos trópicos, onde quantidade potencial de queimadas é ainda enorme (Fearnside et al., 1993). Verifica-se assim, que dados sobre esses parâmentros a partir da queima da floresta nos trópicos torna-se imprescindível, para que estimativas sobre emissões de gases de efeito estufa nos trópicos sejam mais precisas.

A formação de cinzas é outro fenômeno resultante da queima da biomassa. As cinzas raramente são mencionadas em estudos relacionados com emissão de carbono possivelmente por contribuir pouco em termos de carbono no estoque total de carbono da floresta depois de queimar. No entanto, elas são de grande interesse em estudos de ciclagem de nutrientes, por provocar grandes alterações nas propriedades químicas do solo (Smyth \& Bastos, 1984; Hernani et al., 1987; Gonçalves \& Moro, 1995). Entretanto, a quantificação e a análise do conteúdo de nutrientes nas cinzas de material vegetal originário de floresta são, também, raros. Dantas \& Matos (1981) afirmaram que a produção de cinzas depende, principalmente, da biomassa da vegetação e do tipo de queimada. A produção de cinzas é, em grande parte, responsável pelas alterações no $\mathrm{pH}$ e na grande disponibilidade de nutrientes nos solos de áreas recém queimadas (Brinkmann 
\& Nascimento, 1973). A produção de cinzas tem grande papel na agricultura migratória, sendo citada por alguns autores como responsável pela melhoria da fertilidade do local a ser cultivado (Fearnside, 1989).

c) Mudanças no estoque de carbono no solo após queima da floresta.

Estudos quantificando estoque de carbono do solo antes e imediatamente após a queima da biomassa florestal têm observado apenas leves alterações no conteúdo de carbono no solo, restritas principalmente às camadas mais superficiais.

Sánchez (1976) mencionou que o conteúdo de carbono do solo é pouco afetado pela queima, embora tenha um efeito significativo na redução dos estoques de carbono, enxôfre e nitrogênio da biomassa vegetal acima do solo. Isto porque as temperaturas do solo durante a queimada não são altas o suficiente por longo período de tempo durante a combustão. Exceto na requeima em situação de empilhamento do material combustível (coivara).

Estudos feitos por Nye \& Greenland (1964), em Gana, e Seubert (1975), no Peru, mostraram um pequeno aumento no carbono orgânico do solo após a queima. Este aumento tem sido atribuído a adição de fragmentos vegetais, oriundos da combustão incompleta do material combustível sobre o solo, e de partículas de carvão como carbono orgânico.

Ewel et al. (1981) estudando o efeito da queima numa floresta secundária de 9 anos, observaram que a temperatura caiu drasticamente de aproximadamente $200{ }^{\circ} \mathrm{C} \mathrm{em}$ média na superfície do solo para uma média de $100{ }^{\circ} \mathrm{C}$ a $1 \mathrm{~cm}$ de profundidade, chegando a menos de $38{ }^{\circ} \mathrm{C}$. em média, na camada inferior a $3 \mathrm{~cm}$ de profundidade. Eles constataram que a temperatura variou consideravelmente entre os pontos observados, dependendo da qualidade do combustível, quantidade e da umidade. Concluiram que após a queimada uma quantidade substancial de carbono no solo e nitrogênio foram conservados e que apenas o enxôfre sofreu grandes perdas. 
Teixeira \& Bastos (1989) não encontraram diferença estatisticamente significativa entre o percentual de carbono orgânico de uma floresta primária, próxima de Manaus, antes e 4 meses depois da queima, nas camadas de 0-10, 10-20, 20-40 e 40 a $100 \mathrm{~cm}$.

Martins et al. (1990), encontraram uma pequena redução, cerca de $4 \%$, na quantidade de carbono armazenada no solo numa área recém queimada de floresta primária em Capitão Poço, no Pará. Verificou, também, que a distribuição do carbono em relação a profundidade foi $17 \%$ menor entre as camadas de 0 a $20 \mathrm{~cm}$, seguido de um acréscimo de carbono entre 50 e $100 \mathrm{~cm}$, compensando em parte a perda sofrida nas camadas mais superficiais. Constou-se uma diferença mais acentuada entre o sistema natural e o queimado nos primeiros dez centímetros.

Cerri et al. (1991), também, estudando o efeito da queimada na matéria orgânica do solo numa área de floresta primária, próxima de Manaus, observaram uma tendência na redução do estoque de carbono orgânico no solo de $73,1 \mathrm{t} \mathrm{ha}{ }^{-1}$ numa profundidade de 0 a $20 \mathrm{~cm}$ antes da queima, para $63,7 \mathrm{tha}^{-1}$ imediatamente após a queima.

Kauffman et al. (1995), observaram que não houve tendências significantes ou mudanças dramáticas nos conteúdos totais de $\mathrm{C}$ e $\mathrm{N}$ no solo após a queimada em quatro locais de floresta primária no Pará e em Rondônia.

Em geral, espera-se que as modificações no conteúdo de carbono do solo em áreas recém queimadas sejam bastante moderadas, principalmente quando comparadas com aquelas sofridas pela biomassa vegetal. No entanto, há uma grande polêmica em relação as alterações que o estoque de carbono do solo possa sofrer com as mudanças associadas ao uso da terra a longo prazo.

Bogdonoff et al. (1985) relataram que mudanças associadas ao uso da terra são responsáveis em afetar, de forma complexa, o estoque de carbono na vegetação e no solo. Consequentemente, estas mudanças afetarão a troca de carbono entre os ecossistemas terrestres e a atmosfera. Afirmaram, também, que os estoques de carbono no solo são afetados principalmente pela intensidade e pelo tipo de uso que serão destinados à área original. 
Espera-se que haja uma liberação do carbono do solo quando a floresta é convertida em pastagem porque a temperatura do solo aumenta. geralmente aumentando a taxa de decomposição quando a cobertura florestal é removida. mudando desta maneira o balanço entre a formação e a degradação a um nível de equilibrio mais baixo (Cunningham, 1963; Nye \& Greenland, 1960). Entretanto os resultados encontrados são bastante variados. Alguns autores têm encontrado uma redução no estoque de carbono do solo em pastagens (Falesi, 1976; Fearnside, 1980; Hecht, 1982). Porém, outros têm encontrado estoques de carbono no solo da pastagem maiores ou semelhante a da floresta original, decorrido alguns anos da sua conversão em pastagem (Bushbacher, 1984; Keller et al., 1986, Cerri et al., 1991; Reiner et al. 1994; Moraes et al.. 1996).

Trumbore et al., (1995), afirmaram que as alterações no conteúdo de carbono no solo acompanhadas pela mudança no uso do solo são quase impossíveis de serem detectadas medindo-se apenas as concentrações de carbono no solo. Isto, porque não revelam a dinâmica da ciclagem do carbono. Desta maneira, sugerem o emprego de técnicas isotópicas com carbono marcado para acompanhar alterações no conteúdo de carbono no solo em florestas convertidas em pastagens.

Houghton (1990) considerou que a floresta convertida em pastagens tem uma perda líquida de carbono menor do que culturas anuais, porque estas quando perenes adicionam carbono ao solo o que não ocorre com culturas anuais. Esse acúmulo de carbono pelas pastagens pode ser explicada pela sua alta produção de raízes (Cerri et al., 1991). No entanto, como observado foi por Trumbore et al.. (1995), as pastagens degradadas (ao contrário das pastagens manejadas) são menos produtivas do que as florestas substituidas por elas. Consequentemente, a reduzida entrada de carbono no solo pelas pastagens degradadas levará a uma redução no conteúdo de carbono do solo.

As incertezas a respeito dessa questão indicam que mais estudos devem ser feitos a fim de esclarecer o real comportamento desse elemento após mudanças no uso do solo. 


\section{MATERIAL E MÉTODOS}

\subsection{Localização, vegetação, solo e clima da Amazônia Legal}

A Amazônia Legal é uma região político administraviva, criada pela Lei ํํำ 1806 em 1953, que abrange os estados do Acre, Amazonas, Roraima, Pará, Amapá, Mato Grosso, Rondônia, parte ocidental do Maranhão com limite na longitude de $44^{\circ} \mathrm{W}$ (Figura 2) e de Tocantins com limite na latitude $13^{\circ} \mathrm{S}$, totalizando uma área de 5 milhões de $\mathrm{km}^{2}$. Sua área extrapola a região formada pela bacia amazônica, incluindo áreas do Planalto Central com vegetação de cerrado.

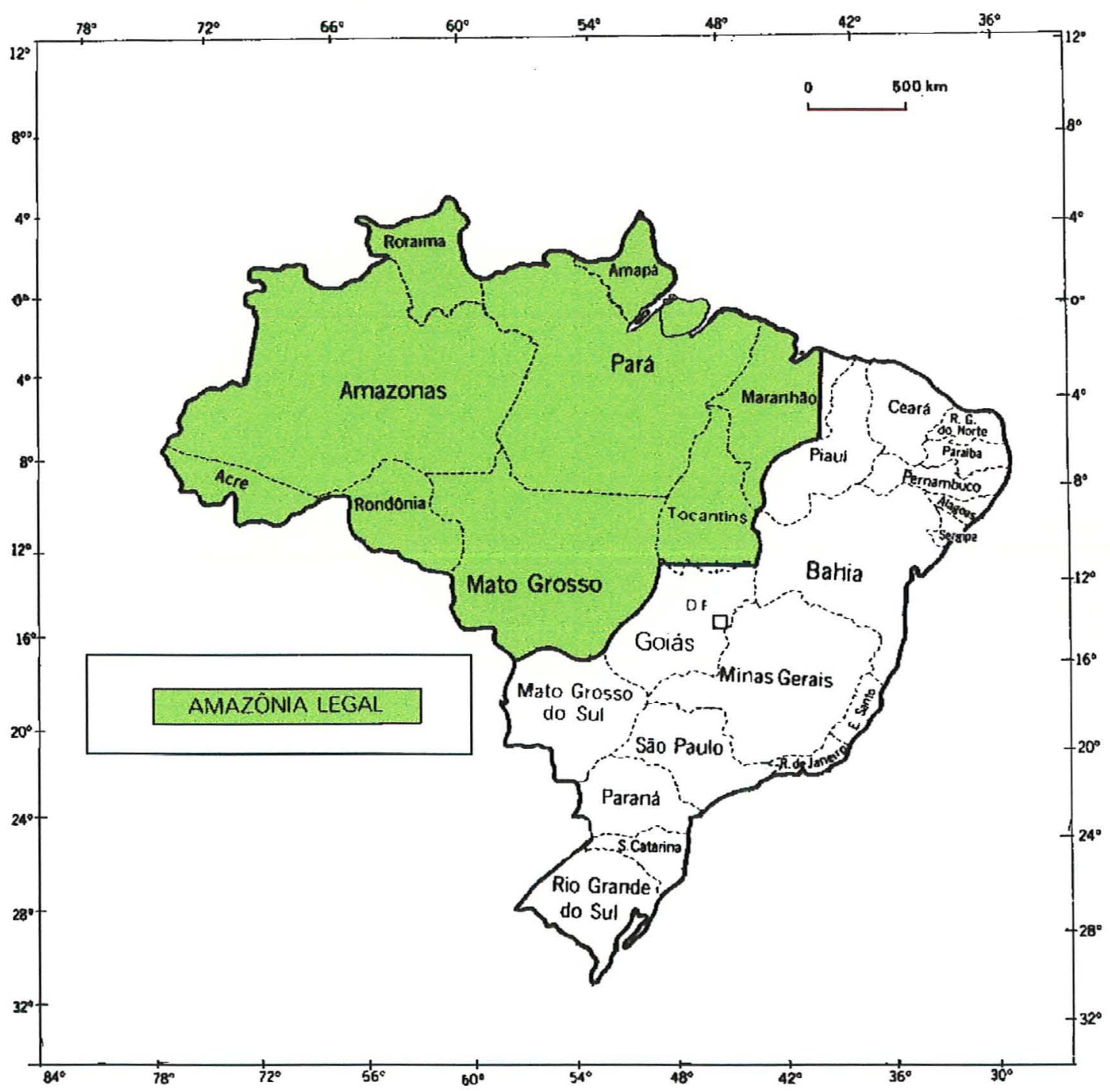

Figura 2. Mapa esquemático da localização da Amazônia Legal. 
A formação florestal de terra firme cobre maior parte, cerca de $70 \%$, da Amazônia Legal. As formações florestais segundo a classificação fitogeográfica feita pelo PROJETO RADAMBRASIL são compostas por florestas ombrófilas densas e aberta (Figura 3), florestas estacionais semidecíduas e decíduas e manguezais. Outros tipos de formações não florestais, também, compõem a vegetação na Amazônia, tais como, savanas (cerrados) ( Figura 3), campinas e campos. Há também áreas de contato entre as diferentes formações, denominadas pelo RADAMBRASIL, como áreas de tensão ecológica, e por último áreas formadas pela ação antrópica.
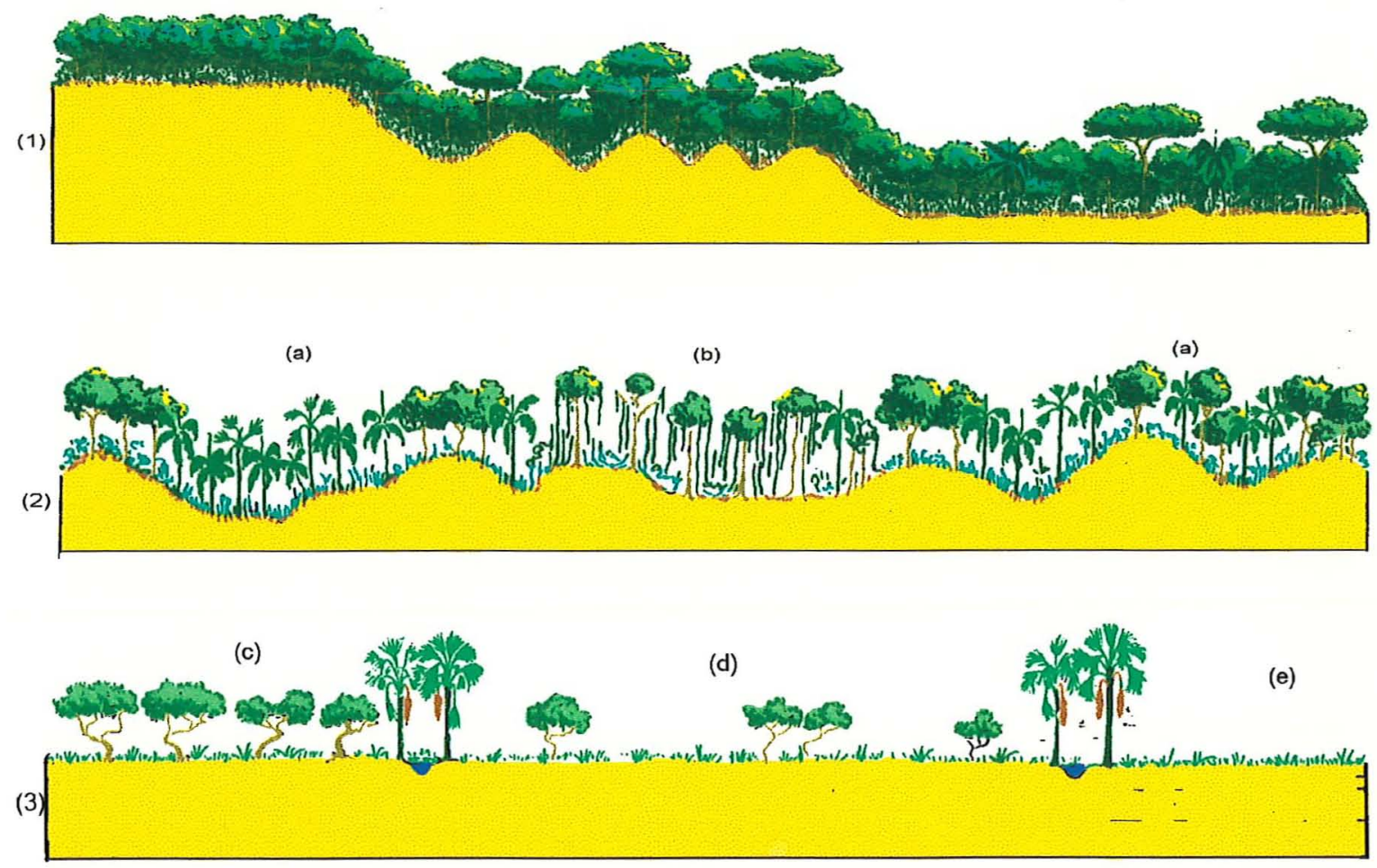

Figura 3. Perfis esquemáticos de três principais ecossistemas da Amazônia (1) Floresta tropical densa com árvores emergentes; (2) Floresta tropical aberta: (a) com palmeiras, (b) e com cipó; (3) Savana (cerrado): (c) arbórea aberta, (d) parque e (e) graminosa (Adaptado de Projeto RADAMBRASIL, vol. 8, 1975; vol.12, 1976.). 
Aproximadamente $60 \%$ da área da Amazônia Legal é representada por três tipos de solos, latossolos amarelos (Oxisols), latossolos vermelho-amarelos (Oxisols) e podzólicos vermelho-amarelos (Ultisols e Alfisols). Em geral, são solos ácidos e de baixa fertilidade (Moraes et al., 1995). A distribuição percentual de cada tipo de solo na Amazônia Legal de acordo com o mapa de solos elaborado pela EMBRAPA (1981) está representada na Figura 4.

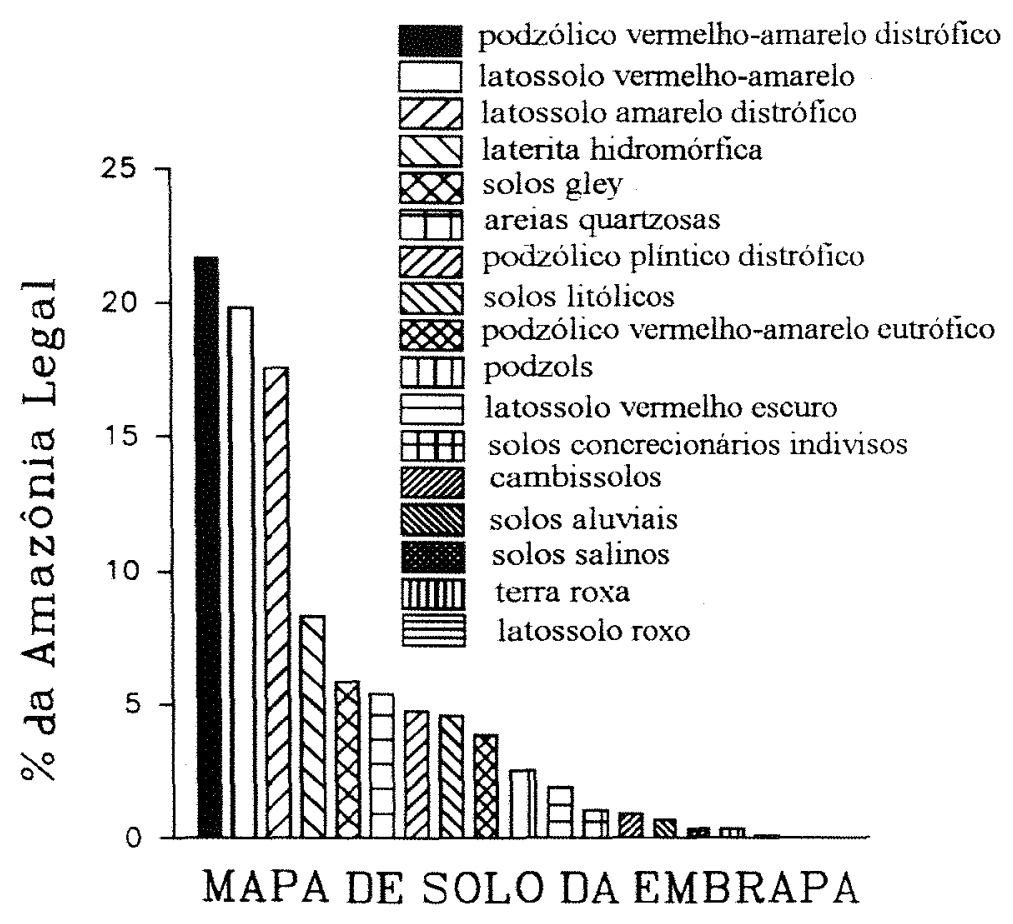

Figura 4. Distribuição relativa de dezessete classes de solo na Amazônia Legal de acordo com o sistema de classificação da Empresa Brasileira de Pesquisa Agropecuária (EMBRAPA), adaptado de Moraes, et al. (1995).

O clima na Amazônia segundo a classificação de Köppen pertence ao grupo de clima chuvoso $\mathbf{A}$, onde a temperatura média dos meses mais quentes nunca é inferior a 18 ${ }^{\circ} \mathrm{C}$. Este grupo compreende os tipos climáticos Af, Am e Aw, semelhantes com a relação a oscilação anual de temperatura que é inferior a $5{ }^{\circ} \mathrm{C}$, pertencendo assim a variedade $\mathbf{i}$, sem verão nem inverno estacional (Vieira \& Santos, 1987). Os tipos climáticos foram descritos a seguir: 
Tipo Afi - Caracteriza-se por representar chuvas relativamente abundantes durante todo o ano, onde a altura da chuva do mês de menor precipitação é sempre superior a $60 \mathrm{~mm}$. Ocorre na maior parte do Estado do Amazonas, na área limitada pelo médio curso do rio Coari e pelo rio Negro, até atingir a cidade de Manaus. Aparece também no Estado do Pará, em torno de Belém, atingindo a parte do Amapá (Figura 5).

Tipo Ami - Apresenta um regime pluviométrico anual que define uma estação seca. porém com total pluviométrico anual suficiente para manter este periodo. Abrange grande parte do Amapá, sudeste de Roraima, sul de Rondônia e grande parte dos Estados do Pará, Acre e Amazonas (Figura 5).

Tipo Awi - Possui índice pluviométrico anual relativamente elevado com nítida estação seca. Este tipo é encontrado em uma pequena extensão na parte norte da Amazônia, abrangendo os Estados do Amapá, Tocantins e de Roraima e parte do Estado do Pará. Aparece também ao sul e sudeste nos Estados do Maranhão e Mato Grosso (Figura 5).

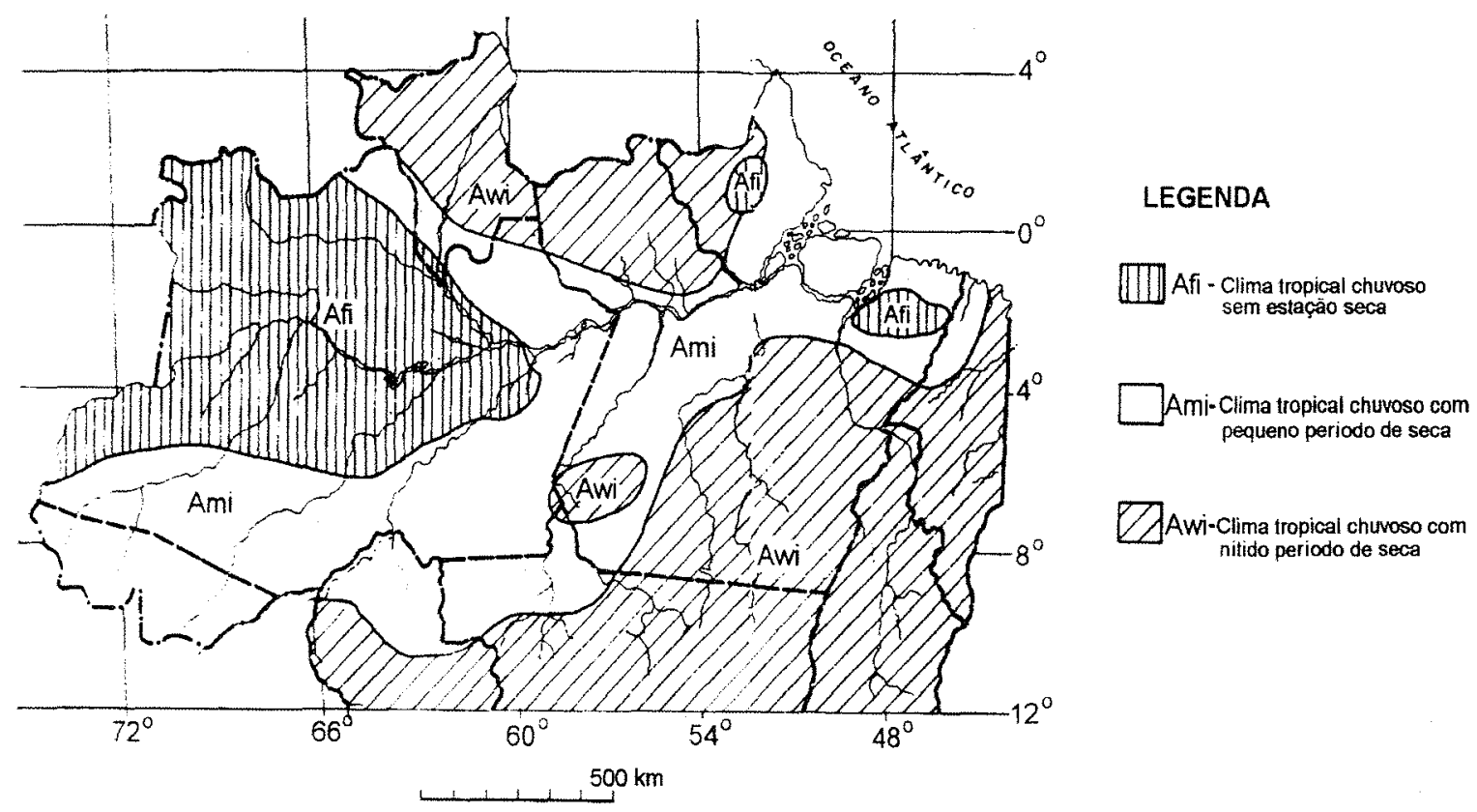

Figura 5. Tipos climáticos da Amazônia segundo o sistema de classificação de Köppen (adaptado de Vieira \& Santos, 1987) 


\subsection{Localização e caracterização ambiental da área de estudo em Rondônia}

Este estudo foi realizado na Fazenda Nova Vida (Figuras 6 e 7), no municipio de Ariquemes no Estado de Rondônia, a $10^{\circ} 10^{\prime} 5^{\prime \prime}$ de latitude Sul e $62^{\circ} 49^{\prime} 27^{\prime \prime}$ de longitude Oeste. A fazenda possui uma área total de 20.000 ha e sua principal atividade é a agropecuária. A sede da Fazenda Nova Vida está localizada no km 472 da rodovia BR364. entre Ariquemes e Jaru. A área experimetal possui aproximadamente 3,5 ha. Neste local a floresta primária foi cortada e queimada para implantação de pastagem.

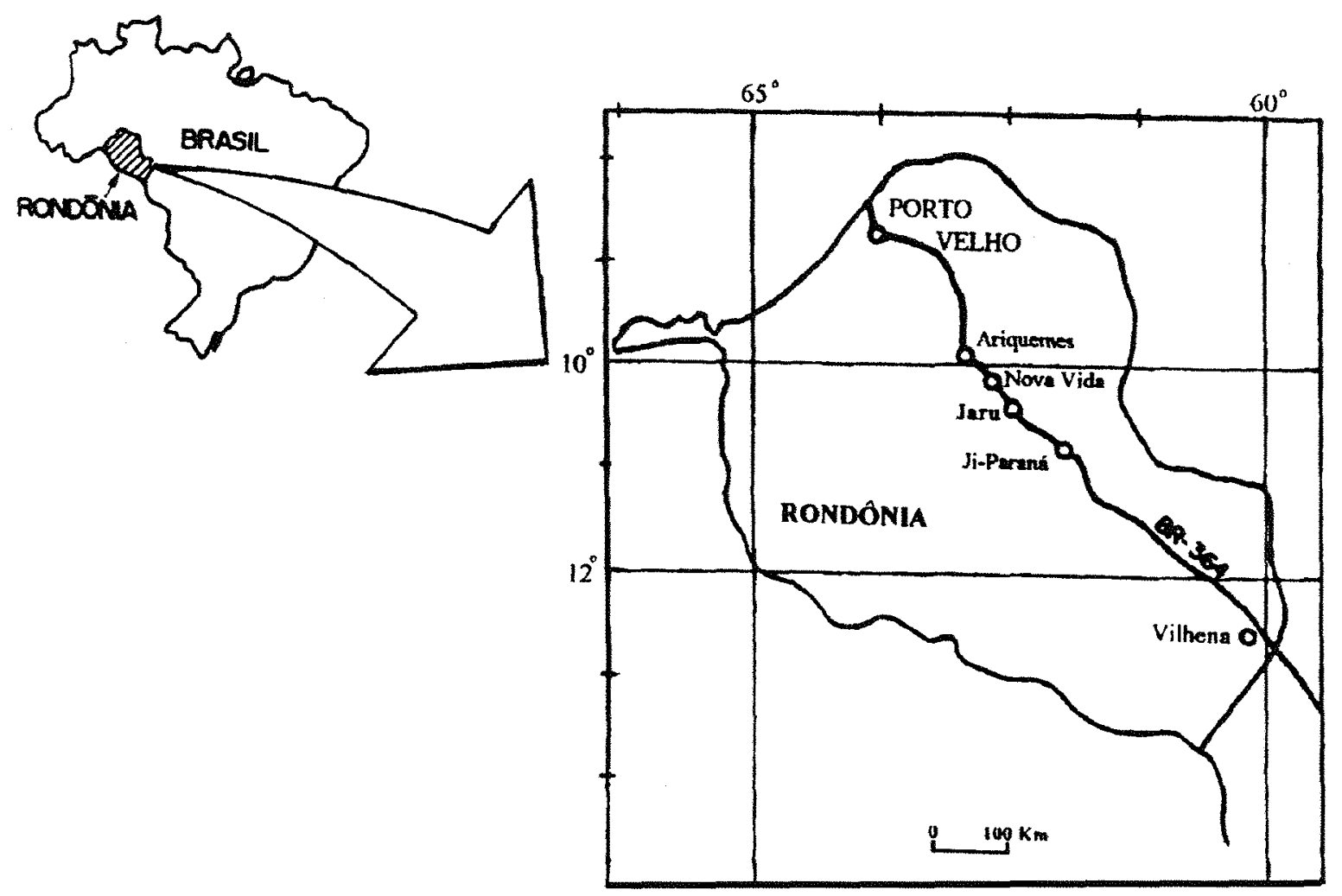

Figura 6. Mapa esquemático da localização da Fazenda Nova Vida 


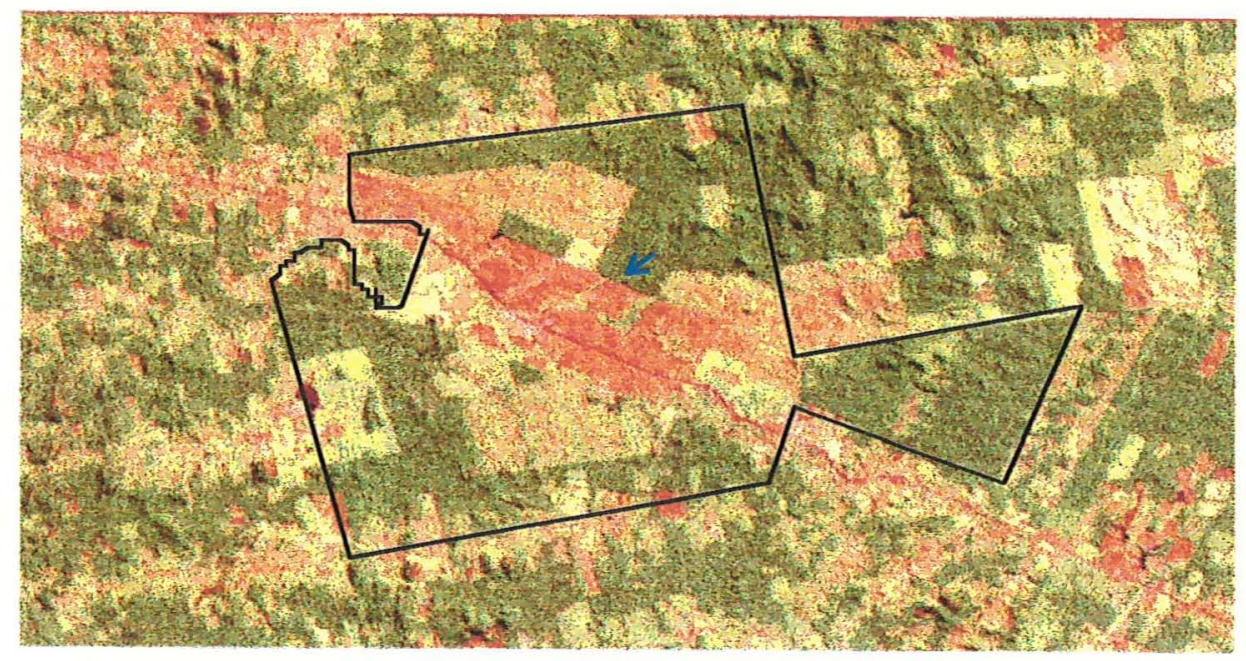

Figura 7. Imagem Landsat/TM (composição colorida 3B4G5R) apresentando a área da Fazenda Nova Vida. A área circundada pela linha mostra os limites da fazenda e a seta indica o local onde foi realizado o experimento.

A vegetação é caracterizada como floresta tropical aberta, com grande número de palmeiras (Projeto RADAMBRASIL, 1978; Pires \& Prance, 1985). Nelson (1992), descreve este tipo florestal como sendo de dossel geralmente mais plano do que a floresta densa, com poucas árvores emergentes e altura média de 25 metros ou menor. O subbosque é mais aberto com maior distância entre árvores e maior penetração de luz. Visto de cima, as palmeiras maiores se evidenciam quando presentes, dando a origem à expressão "floresta aberta com palmeiras". Segundo Pires \& Prance (1985) as palmeiras mais freqüentes são Orbignya barbosiana (babaçu), Oenocarpus sp. (bacaba), Jessenia bataua (patauá), Euterpe precatoria (açaí da mata) e Maximiliana regia (inajá).

$\mathrm{O}$ solo da área de estudo foi classificado como podzólico vermelho-amarelo latossólico (Moraes et al., 1996), também classificado como Kandiuldult pela taxonomia americana de solos, de textura média, argilo arenosa. Ele ocorre na região em situações de topo e na parte superior das encostas convexas de baixas colinas. As características químicas e físicas deste solo sob a floresta estão apresentados na Tabela 2. 
Tabela 2. Algumas características químicas ${ }^{1}$ e fisicas ${ }^{2}$ do solo sob a floresta na Fazenda Nova Vida, Ariquemes. RO.

\begin{tabular}{|c|c|c|c|c|c|c|c|c|c|c|c|}
\hline \multirow{2}{*}{$\begin{array}{l}\text { Prof. } \\
\text { (cm) }\end{array}$} & \multicolumn{2}{|c|}{$\mathrm{pH}$} & $\mathrm{H}+\mathrm{Al}$ & $\mathrm{H}$ & $\mathrm{Al}^{3+}$ & $\mathrm{Ca}^{2+}$ & $\mathrm{Mg}^{2+}$ & $\mathrm{K}^{+}$ & $\mathrm{CTC}$ & \multirow{2}{*}{$\begin{array}{c}P \\
\left(m g d m^{-3}\right)\end{array}$} & \multirow{2}{*}{$\begin{array}{c}\mathrm{V} \\
(\%)\end{array}$} \\
\hline & $\left(\mathrm{H}_{2} \mathrm{O}\right)$ & $(\mathrm{KCl})$ & \multicolumn{7}{|c|}{$\mathrm{mmol}_{\mathrm{c}} \mathrm{dm}^{-3}$} & & \\
\hline $0-5$ & 5,89 & 5,27 & 19 & 2,6 & 0,4 & 36,7 & 6,8 & 0,7 & 63 & 2,97 & 70,1 \\
\hline $5-10$ & 5,12 & 4,08 & 28 & 2,4 & 2,0 & 11,0 & 5,0 & 0,4 & 44 & 1,65 & 37,3 \\
\hline $10-15$ & 4,52 & 3,72 & 36 & 4,1 & 5,4 & 6,5 & 3,3 & 0,5 & 46 & 0,99 & 22,4 \\
\hline $15-20$ & 4,62 & 3,72 & 38 & 3,8 & 8,1 & 3,7 & 2,2 & 0,4 & 44 & - & 14,3 \\
\hline \multirow[t]{4}{*}{$20-30$} & 4,51 & 3,83 & 38 & 2,9 & 11,7 & 2,2 & 0,7 & 0,4 & 41 & - & 8,0 \\
\hline & & & & & \multicolumn{3}{|c|}{ Textura } & & & Densidade & \\
\hline & & & & & areia & silte & argila & & & $\mathrm{g} \mathrm{cm}^{-3}$ & \\
\hline & & & & & & $\mathrm{g} \mathrm{kg}^{-1}$ & & & & & \\
\hline $0-5$ & & & & & 810 & 10 & 180 & & & 1,20 & \\
\hline $5-10$ & & & & & 690 & 50 & 260 & & & 1,37 & \\
\hline $10-20$ & & & & & 660 & 40 & 300 & & & 1,41 & \\
\hline $20-30$ & & & & & 620 & 30 & 350 & & & 1,44 & \\
\hline
\end{tabular}

'Os dados de análise química do solo foram obtidos de Gomes (1995). $\mathrm{O} \mathrm{H}^{+}$e $\mathrm{Al}^{3+}$ (acidez trocável) expressos separadamente na tabela foram extraídos com $\mathrm{KCl} \perp \mathrm{M}$, enquanto que o $\mathrm{H}+\mathrm{Al}$ (acidez potencial) foi determinado pelo método SMP.

${ }^{2}$ Os dados de análise fisica do solo foram obtidos de Neill et al. (no prelo).

O clima segundo a classificação de Köppen é Ami, possuindo pluviometria anual elevada e com estação seca curta bem definida de junho a agosto. A pluviometria anual é de $2200 \mathrm{~mm}$ (Bastos \& Diniz, 1982) e a sua média anual de temperatura é de $25,6{ }^{\circ} \mathrm{C}$. Apresentando uma média anual de umidade relativa de $89 \%$.

As médias mensais de temperatura e pluviosidade da fazenda Rancho Grande, no período de 1984-1992, localizada a $10 \mathrm{~km}$ da área de estudo, estão representadas na Figura 8. 


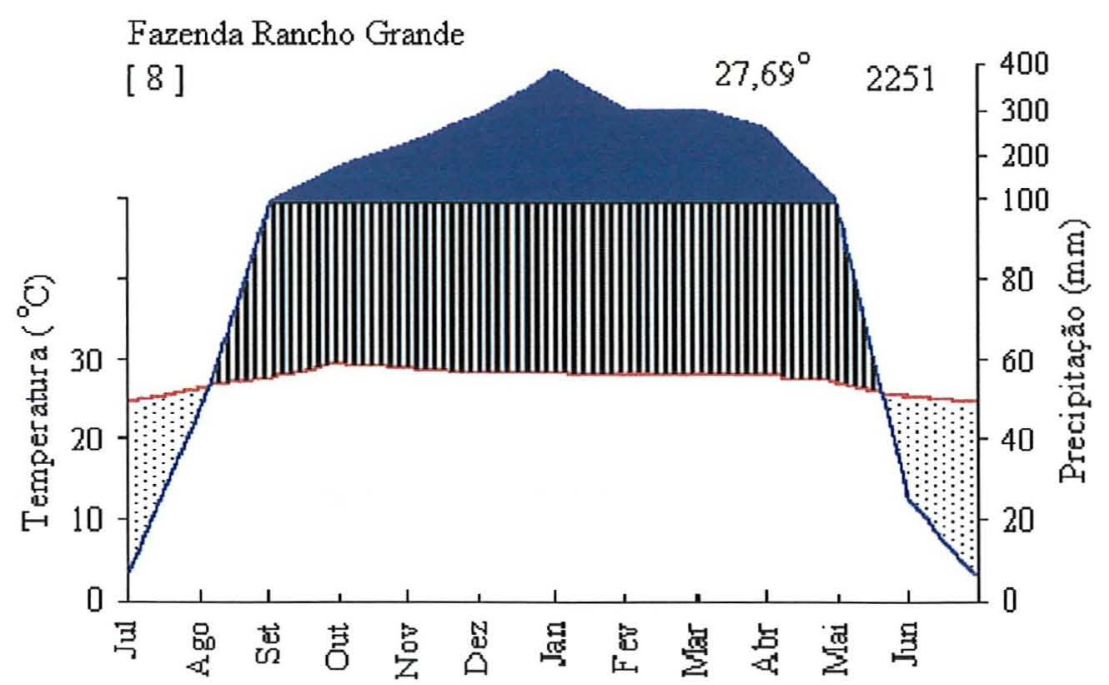

Figura 8. Diagrama climático, segundo modelo de Walter, da fazenda Rancho Grande, Ariquemes, RO, mostrando a variação média de precipitação e de temperatura no período de 1984 a 1992.

\subsection{Estimativa da fitomassa e do estoque de carbono para Amazônia Legal}

O estoque de carbono da fitomassa foi estimado baseado no levantamento de biomassa total (parte aérea e subterrânea) e na extensão da área de cada tipo de vegetação presente na Amazônia Legal. A fitomassa média de cada tipo de vegetação foi obtida ponderando-se pela extensão da sua área.

\subsubsection{Elaboração do mapa de vegetação}

Com a finalidade de se conhecer a área ocupada por cada tipo de vegetação foi gerado um mapa, tendo como base cartográfica o mapa de vegetação da Amazônia Legal, na escala 1:2.500.000, produzido pela SUDAM (Superintendência do Desenvolvimento da Amazônia) juntamente com o IBGE (Fundação Instituto Brasileiro de Geografia e Estatística), em 1989, na escala de 1:2.500.000, a partir de informações geradas pelo Projeto RADAMBRASIL, na escala 1:1.000.000. Os contornos das áreas de vegetação foram copiados à mão para um papel opaco de polietileno (indeformável) 
depois transformado em forma digital através de um "scanner", formato A0, de alta resolução. A imagem gerada pelo "scanner" foi tratada e colorizada usando software OSIRIS ${ }^{1}$.

\subsubsection{Classificação da vegetação do mapa}

Os tipos de vegetação adotados no mapa foram classificados de acordo com o documento elaborado pela SUDAM/IBGE (1989). Neste mapa a vegetação está classificada em trinta classes de vegetação. Assume-se que dezoito destas classes são representadas por tipos florestais, incluindo áreas de transição (ecótonos) entre floresta e tipos não florestais. As outras doze classes são de tipos vegetacionais não florestais, caracterizados por savanas (cerrados), campos e campinas. As classes de vegetação foram agrupadas em seis categorias para facilitar sua interpretação, representadas por florestas densas, florestas abertas, outras florestas não densas, savanas, outras vegetações não florestais e áreas antrópicas. A categoria representada por atividades antrópicas, inclui todos os tipos de alterações provocadas pela atividade humana na vegetação original até o ano de 1988 (de acordo com a interpretação feita no mapa da SUDAM/IBGE, 1989), tais como, áreas cultivadas para uso agrícola e pecuário, áreas degradas (pastagens abandonadas) e áreas em regeneração (florestas secundárias). Uma apresentação mais detalhada desta classificação encontra-se na Tabela 3.

Tabela 3. Tipos de vegetação representados no mapa da Amazônia Legal

\begin{tabular}{lllll}
\hline Categoria & Código & Grupo & Subgrupo & Classe \\
\hline $\begin{array}{l}\text { Floresta } \\
\text { densa }\end{array}$ & $\mathrm{Da}$ & floresta ombrófila & floresta densa & amazônica aluvial \\
& $\mathrm{Db}$ & floresta ombrófila & floresta densa & $\begin{array}{l}\text { amazônica de terras } \\
\text { baixas }\end{array}$ \\
& $\mathrm{Dm}$ & floresta ombrófila & floresta densa & $\begin{array}{l}\text { amazônica montana } \\
\text { amazônica submontana }\end{array}$ \\
& $\mathrm{Ds}$ & floresta ombrófila \\
Floresta & $\mathrm{Ab}$ & floresta ombrófila & aberta & terras baixas \\
aberta & As & floresta ombrófila & aberta & submontana
\end{tabular}

\footnotetext{
${ }^{1}$ Programa computacional desenvolvido pelo Instituit Français de Recherche Scientífique por Le Développment en Coopération. (OORSTOM/SMAI, 1993.
} 
Tabela 3. Tipos de vegetação representados no mapa da Amazônia Legal.

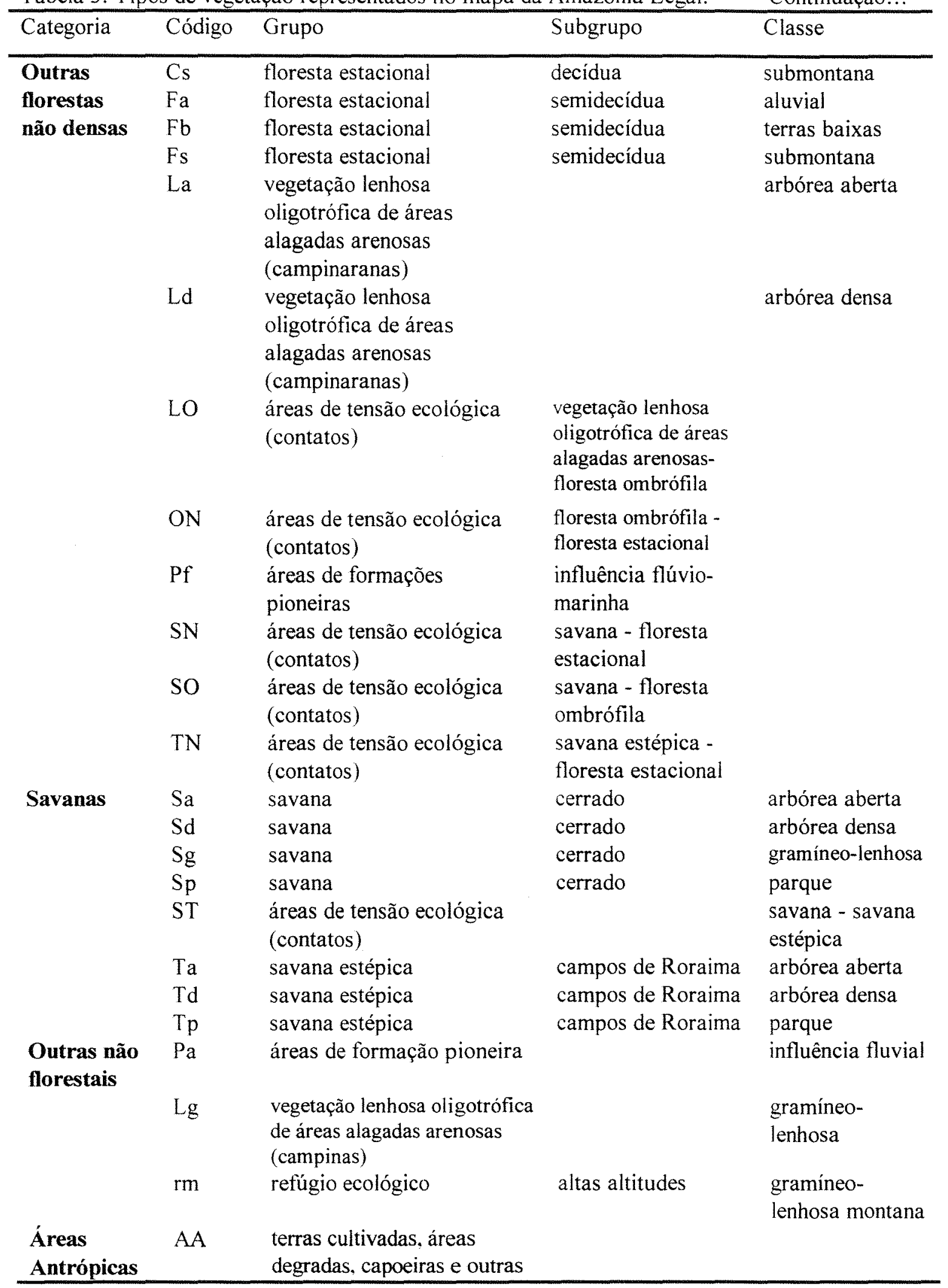




\subsubsection{Cálculos para estimar a área de cada tipo de vegetação}

A área de cada tipo de vegetação foi estimada quantificando-se o número de "pixels" para cada tipo de cor correspondente a cada vegetação presente na imagem do mapa "scaneado". A área ocupada pelos "pixels" do contorno (em preto) foi distribuida ponderadamente para a área ocupada por cada vegetação. Então, foi estabelecida uma relação entre a área da Amazônia Legal, assumida como 5 milhões de $\mathrm{km}^{2}$, e o percentual de "pixels" ocupado por cada área de vegetação, incluindo também a área ocupada pelas

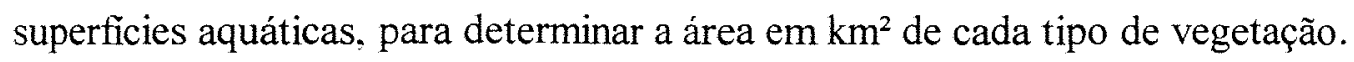

\subsubsection{Cálculos para estimar a fitomassa}

O cálculo da estimativa de fitomassa foi feito separadamente para formações florestais e não florestais.

A biomassa total dos tipos florestais foi estimada utilizando 2.779 dados de volume de madeira, com base em parcelas de 1 ha $(200 \times 500 \mathrm{~m})$, retirados do levantamento feito pelo Projeto RADAMBRASIL (1973-1983), exceto para a vegetação de mangue. Para os tipos não florestais foram utilizados 161 dados de volume de lenha, somente disponíveis para savanas(cerrados) densas e abertas. Áreas com tipos vegetacionais de pouco interesse comercial não foram incluídos nos levantamentos de volume de madeira pelo RADAMBRASIL. A biomassa dos tipos de vegetação não incluídos no levantamento do RADAMBRASIL foi estimada a partir de pequenos levantamentos isolados. geralmente, de interesse ecológico feitos na Amazônia, ou em outras regiões tropicais.

Uma vez que o levantamento florestal feito pelo RADAMBRASIL teve como objetivo estimar o volume de madeira comercializável, considerando apenas árvores com diâmetro na altura do peito (DAP) igual ou maior que $30 \mathrm{~cm}$ (ou precisamente $100 \mathrm{~cm}$ de circunferência) e a altura comercial (altura do fuste até a primeira bifurcação), foi necessário ajustar estas estimativas para serem extrapoladas em termos de biomassa total. Assim, foram adotados os mesmos critérios de ajustes baseados nos trabalhos realizados 
por Brown \& Lugo (1992) e Fearnside (1994) para estimativas baseadas em levantamentos de volume de madeira na Amazônia.

Os dados de volume florestal foram inicialmente corrigidos, utilizando-se os fatores de expansão adotados por Brown \& Lugo (1992) para ajustar a estimativa do volume para as classes de até $10 \mathrm{~cm}$ de diâmetro à altura do peito (DAP). Após a expansão do volume para essas classes transformou-se este valor em biomassa por hectare, através da sua conversão pela densidade aparente de madeiras tropicais, e finalmente expandiu-se esta estimativa de biomassa de troncos em biomassa aérea total. através de um fator de expansão de biomassa adotado pelos mesmo autores. Em seguida, foram feitos ajustes para incluir outros componentes da floresta não considerados na estimativa da biomassa aérea total. Os componentes incluídos na expansão para estimar a biomassa aérea total foram apenas as folhas, os galhos, os troncos e as cascas. Assim. para estimar a fitomassa total foi preciso incluir alguns ajustes para outros componentes da floresta, conforme foi descrito por Fearnside (1994). Desta maneira, foram incluídos ajutes para a biomassa viva acima do solo, para biomassa morta acima do solo e para a biomassa abaixo do solo. A Tabela 4 resume os parâmetros utilizados na derivação da estimativa da fitomassa total a partir dos dados do RADAMBRASIL.

A biomassa das savanas densas ( $\mathrm{Sd}$ ) e abertas ( $\mathrm{Sa}$ ) foram estimadas baseadas em dados de volume de lenha do RADAMBRASIL, a partir de parcelas de 0,5 ha $(250 \times 20$ m), e tiveram como finalidade avaliar o potencial dos cerrados para produção de carvão vegetal. Os resultados de biomassa nestes levantamentos foram expressos em estere', e só foram incluidos os arbustos com circunferência de tronco $\geq 30 \mathrm{~cm}$, medidos a $30 \mathrm{~cm}$ do solo. Nesta estimativa utilizou-se 10 amostras para savana densa e 151 amostras para savana aberta, retirados dos volumes $22,25,26,27$ e 31 , pertecentes aos estados de Mato Grosso, Pará e Tocantins. Destes cerca de $90 \%$ são originários do estado de Mato Grosso.

\footnotetext{
${ }^{1}$ Um estere corresponde a um metro cúbico de lenha empilhada incluindo os espaços vazios entre as peças de madeira.
} 
Tabela 4. Parâmetros para derivar a estimativa de fitomassa de dados de volume florestal do RADAMBRASIL.

\begin{tabular}{|c|c|c|c|}
\hline Derivação & Fator de ajuste & Multiplicador & Fonte \\
\hline $\begin{array}{l}\text { Cálculo do volume de madeira de } \\
\text { fuste para árvores de } \mathrm{DAP} \geq 10 \\
\mathrm{~cm}\end{array}$ & $\begin{array}{l}\text { Fator de expansão } \\
\text { de volume (FEV) }\end{array}$ & $1,25(1)$ & $\begin{array}{l}\text { Brown \& } \\
\text { Lugo(1992) }\end{array}$ \\
\hline $\begin{array}{l}\text { Conversão de volume de madeira } \\
\text { de fuste para biomassa }\end{array}$ & $\begin{array}{l}\text { Fator de expansão } \\
\text { de biomassa } \\
\text { (FEB) }(2)\end{array}$ & & $\begin{array}{l}\text { Brown \& } \\
\text { Lugo (1992) }\end{array}$ \\
\hline $\begin{array}{l}\text { Ajustes para biomassa viva acima } \\
\text { do solo (4) }\end{array}$ & & $1,28(3)$ & $\begin{array}{l}\text { Fearnside } \\
\text { (1994) }\end{array}$ \\
\hline \multirow[t]{2}{*}{ Ajustes para outros componentes } & $\begin{array}{l}\text { Biomassa morta } \\
\text { acima do solo }\end{array}$ & $1,09(5)$ & $\begin{array}{l}\text { Fearnside } \\
\text { (1994) }\end{array}$ \\
\hline & $\begin{array}{l}\text { Biomassa } \\
\text { subterrânea }\end{array}$ & $1,29(5)$ & $\begin{array}{l}\text { Fearnside } \\
\text { (1994) }\end{array}$ \\
\hline
\end{tabular}

(1) $\mathrm{FEV}=1,25$ é usado para florestas densas, ou seja, $80 \%$ do volume das árvores $>10 \mathrm{~cm}$ de DAP estão em árvores $>30 \mathrm{~cm}$ de DAP. Para outras florestas não densas o FEV é igual a $1,50(67 \%$ do volume $>$ $30 \mathrm{~cm}$ DAP).

(2) $\mathrm{FEB}=\operatorname{Exp}(3,213-(0,506 \ln (\mathrm{BP})))$ para $\mathrm{BP}<190 \mathrm{t} \mathrm{ha}^{-1}$; e 1,74 para BP> $190 \mathrm{tha}^{-1}$, onde $\mathrm{BP}=$ biomassa do povoamento em $\mathrm{t} \mathrm{ha}^{-1}$ para árvores $>10 \mathrm{~cm}$ de DAP. BP é calculado multiplicando-se densidade da madeira pelo volume de madeira. Sendo que o volume de madeira é o valor de volume publicado pelo RADAMBRASIL, multiplicado pelo fator de expansão de volume apropriado; a densidade da madeira é 0,69 usado por Brown \& Lugo (1992).

(3) Este valor corresponde aos ajustes para os componentes da biomassa viva acima do solo para: as árvores ocas; os cipós; as palmeiras; as árvores < $10 \mathrm{~cm}$ de DAP; as árvores entre $30-31,8 \mathrm{~cm}$ de DAP; os outros componentes não arbóreos; a densidade e o volume para cascas; a densidade e o volume para o alburno; e a correção para o fator de forma das árvores.

(4) Os ajustes para a biomassa viva acima do solo são em relação aos valores de biomassa definido por Brown \& Lugo (1992), enquanto que os ajustes para outros componentes estão relacionados à biomassa acima do solo depois das correções acima.

(5) Estes valores correspondem aos ajustes considerados por Fearnside (1994) para a biomassa morta acima do solo, incluindo: madeira morta e a serapilheira; e para a biomassa viva subterrânea: raizes superficiais (até $1 \mathrm{~m}$ de profundidade), raizes profundas (abaixo de $1 \mathrm{~m}$ de profundidade) e fustes subterrâneos.

Os dados de volume em esteres foram convertidos em biomassa usando os fatores de conversão da Tabela 5. Essas estimativas foram extrapoladas para vegetação de savana estépica densa (Td) e savana estépica aberta (Ta), conforme seus respectivos tipos vegetacionais correspondentes. 
Tabela 5. Fatores para conversão de volume de lenha de savanas ( $\mathrm{st} \mathrm{ha}^{-1}$ ) em biomassa total ( $\mathrm{t} \mathrm{ha}^{-1}$ ), a partir dos dados do RADAMBRASIL

\begin{tabular}{lcl}
\hline Derivação & Fator multiplicador & Fonte \\
\hline $\begin{array}{l}\text { Conversão de volume de lenha para } \\
\text { biomassa }\end{array}$ & $0,39(1)$ & Fearnside (1992b) \\
Ajuste para biomassa aérea (2) & $1,12(3)$ & $\begin{array}{l}\text { Fearnside (1992b); } \\
\text { Kauffman et al. (1994) } \\
\text { Ajuste para biomassa subterrânea }\end{array}$ \\
\hline
\end{tabular}

(1) $390 \mathrm{~kg}$ peso seco/estere para o cerrado em Carajás (valor usado por Fearnside, 1992b).

(2) Assume-se um acréscimo na biomassa aérea de 3 tha de gramíneas para savanas (cerrado) abertas (Kauffman et al., 1994).

(3) Assume-se um fator multiplicador de 1,12 para a fração de 0-10 $\mathrm{cm}$ usado para floresta e que a lenha é maior do que $10 \mathrm{~cm}$ de diâmetro (adotado por Fearnside, 1992b)

(4) Assume-se que a biomassa subterrânea é igual a $36 \%$ do total da biomassa (usado por Seiler \& Crutzen, 1980).

Outras formações não florestais não tiveram seus volumes avaliados pelo RADAMBRASIL por serem restritos às pequenas áreas, com pouco interesse para exploração comercial. Esses tipos de vegetação foram extrapolados de outras fontes, disponíveis na literatura, a partir de levantamentos locais, geralmente de interesse ecológico.

Entre estas formações estão tipos vegetacionais, $\mathrm{Sp}, \mathrm{Sg}, \mathrm{Pf}, \mathrm{Pa}, \mathrm{Lg}$ e Rm. A estimativa de biomassa de savana parque $(\mathrm{Sp})$ foi extrapolada para a vegetação de savana estépica parque (Tp). A área de contato entre savana estépica e savana foi obtida assumindo-se um valor médio entre as estimativas de savana densa e savana aberta.

As áreas com atividades antrópicas (AA) foram estimadas considerando-se o percentual da área ocupada pela cobertura vegetal que substitui a vegetação original e a sua biomassa $\left(\mathrm{t} \mathrm{ha}^{-1}\right)$. Os percentuais para as áreas afetadas pela atividade humana foram baseados nos mesmos valores percentuais adotados por Fearnside \& Guimarães (1996) para áreas com mudança no uso da terra na Amazônia Legal até o ano de 1990. Assumese aqui que essas proporções eram as mesmas em 1988, quando o mapa foi elaborado. As classes estão agrupadas nos seguintes tipos de uso:

- agricultura: $5 \%$ da área desmatada e biomassa del $\mathrm{t} \mathrm{ha}^{-1}$;

- pastagem produtiva: $45 \%$ da área desmatada e biomassa de $11 \mathrm{t} \mathrm{ha}^{-1}$; 
- pastagem degradada: $2,2 \%$ da área desmatada e biomassa de $3,4 \mathrm{t} \mathrm{ha}^{-1}$;

- florestas secundárias de áreas agrícolas: $2 \%$ da área desmatada e biomassa de $29 \mathrm{t} \mathrm{ha}^{-1}$;

- florestas secundárias de pastagens: $28 \%$ da área desmatada e biomassa de $44 \mathrm{t} \mathrm{ha}^{-1}$;

- florestas secundárias antigas (desmatadas antes de 1970): 17\% da área desmatada e biomassa de148 $\mathrm{tha}^{-1}$.

A biomassa total presente na vegetação de áreas antrópicas ponderada para $100 \%$ da área desmatada é igual a 43,5 $\mathrm{t} \mathrm{ha}^{-1}$.

\subsubsection{Cálculos para estimar o estoque de carbono da vegetação}

A estimativa do estoque de carbono presente na fitomassa foi feita através da média ponderada da biomassa total (acima e abaixo do solo) de cada tipo de vegetação em relação a área ocupada na Amazônia Legal, considerando-se que o conteúdo de carbono da fitomassa seja igual a $50 \%$, ou seja, cada tonelada de massa seca posui $0,5 \mathrm{t}$ de carbono, a não ser quando explicitado. O valor de $50 \%$ para o teor de carbono da biomassa é comumente empregado por pesquisadores para estimar o estoque de carbono da vegetação na Amazônia (Brown \& Lugo, 1992; Fearnside, 1994).

\subsection{Estimativa e transformações da fitomassa em Rondônia}

A fitomassa no local do experimento em Ariquemes (RO) foi estimada antes e após a derrubada da floresta. Para avaliar a biomassa das árvores em pé, utilizou-se o método indireto por inferência alométrica. Os métodos empregados para estimar a fitomassa após a derrubada foram: o método direto através da colheita destrutiva e o indireto pela amostragem por linha de interseção. Estes serviram para avaliar as transformações da fitomassa pela queima. 


\subsubsection{Estimativa da biomassa florestal em pé por inferência alométrica}

A área de amostragem da biomassa da floresta em pé foi instalada no centro da área onde posteriormente foi realizado o desmatamento, conforme a figura 9. Esta foi subdividida em 25 parcelas de $400 \mathrm{~m}^{2}$ ( $\left.20 \times 20 \mathrm{~m}\right)$, totalizando uma área de 1 ha.

Este levantamento teve por finalidade estimar a biomassa total das árvores em pé acima do solo, através da relação alométrica entre o diâmetro à altura do peito (DAP) e a altura total das árvores, empregado geralmente em inventários florestais, e comparar futuramente com a estimativa após a derrubada da floresta.

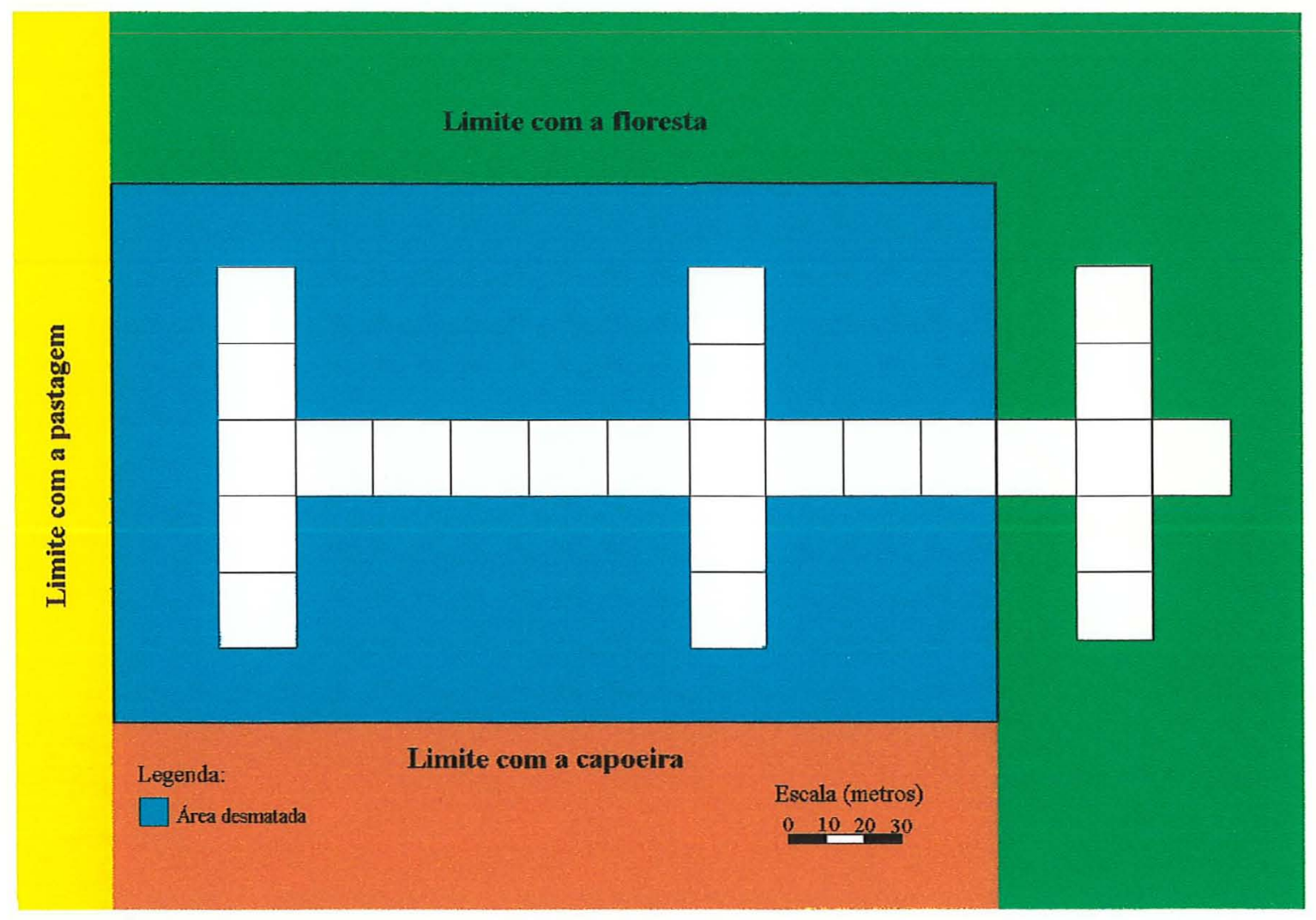

Figura 9 - Esquema das parcelas de levantamento florestal

A altura das árvores foi medida com auxílio de uma vara de $5 \mathrm{~m}$ de comprimento. As medidas obtidas pela vara foram periodicamente comparadas com medições feitas por uma "prancheta dendrométrica", baseadas em relações trigonométricas, a fim de serem 
aferidas. Foram feitas as medidas da altura total da árvore, da sua base até o limite superior da copa, e da altura comercial (fuste reto), da sua base até a primeira bifurcação da árvore. A medida de altura das árvores em florestas tropicais nativas, é difícil, pois a superposição das copas em diferentes estratos dificultam a visualização do limite superior e impossibilita a utilização de equipamentos especializados para sua medição. A medida da circunferência do tronco das árvores foi obtida utilizando-se uma fita métrica, com escala em centímetros, a $1,30 \mathrm{~m}$ do solo e posteriormente feita a sua conversão em diâmetro.

Neste estudo foram empregados os mesmos parâmetros utilizados na equação alométrica desenvolvida por Brown. et al. (1995), para estimar a biomassa aérea de floresta aberta, localizada na Estação Ecológica da Represa Hidrelétrica de Samuel (RO). A equação adotada foi:

Biomassa por árvore $(\mathrm{t})=a * S * B A * H$

onde:

$a=$ coeficiente de regressão

$S=$ densidade básica da madeira $\left(\mathrm{t} \mathrm{m}^{-3}\right)$

$B A=$ área basal $\left(\mathrm{m}^{2}\right)$

$H=$ altura total $(\mathrm{m})$

Substituindo-se os parâmetros da equação (1) pelos os valores encontrados por Brown et al. (1995) para o coeficiente de regressão e densidade da madeira obteve-se a seguinte equação:

Biomassa $($ Kg por árvore $)=0,62 * 0,67 * B A^{*} H^{*}\left(0,1 \mathrm{~kg} \mathrm{~m}^{-2} \mathrm{t}^{-1} \mathrm{~cm}^{-2}\right)$

ou

Biomassa (kg por árvore) $=0,0326 * D^{2} * H$

onde;

$\mathrm{D}=$ diâmetro à altura do peito $(\mathrm{cm})$

$\mathrm{H}=$ altura total $(\mathrm{m})$ 
A equação (2) foi modificada, substituindo-se o valor de 0,67 por 0,62 , que é a densidade dos troncos encontrada em Ariquemes (a partir da amostras coletadas destrutivamente), resultando na equação a seguir:

Biomassa (kg por árvore) $=0,03844 * D^{2} * H$

onde; D é o diâmetro à altura do peito $(\mathrm{cm})$ e H é a altura total em (m).

A biomassa das árvores em pé, que encontravam-se sem copa, foi estimada pela seguinte equação:

$$
\mathrm{B}_{\mathrm{f}}=\mathrm{AB} * \mathrm{H}_{\mathrm{f}} * f * \mathrm{~S}
$$

onde; $\mathrm{B}_{\mathrm{f}}$ é a biomassa do tronco em peso seco ( $\mathrm{kg}$ por árvore), $\mathrm{AB}$ igual a área basal $\left(\mathrm{m}^{2}\right), \mathrm{H}_{\mathrm{f}}$ igual a altura do tronco $(\mathrm{m}), f$ é o fator de forma e $\mathrm{S}$ da densidade básica da madeira $\left(\mathrm{kg} \mathrm{m}^{-3}\right)$. Considerando-se $f$ igual a 0,78 , conforme foi empregado por Fearnside (1992a) para estimar volume do tronco de árvores na Amazônia, com diâmetro à altura do peito acima de $10 \mathrm{~cm}$, tomando-se em conta a altura comercial (distância do chão até o primeiro galho). Então a equação (5) foi expressa da seguinte maneira.

$$
\mathrm{B}_{\mathrm{f}}=0,6131 * \mathrm{D}^{2} * \mathrm{H}_{\mathrm{f}} * \mathrm{~S}
$$

\subsubsection{Avaliação das transformações da biomassa florestal aérea pela queima, na área derrubada}

Foram empregados dois métodos para avaliar as transformações ocorridas na biomassa pela queima: o direto ou de colheita destrutiva e o método indireto, através da amostragem por linhas de interseção (transectos). Foi derrubada uma área florestal de aproximadamente. 3,5 ha, com a finalidade de avaliar o estoque de carbono da fitomassa, a eficiência de combustão, a formação de carvão e a liberação de carbono.

O processo da derrubada foi iniciado no dia 15 de junho e terminou no dia 26 junho de 1995. O corte da floresta foi feito conforme os métodos tradicionalmente empregados pelos fazendeiros da região. As árvores foram cortadas utilizando-se a motosserra, que tem substituído o machado em áreas recentes de colonização na 
Amazônia. Após a derrubada da floresta, deixou-se a fitomassa noventa e oito dias secando ao ar livre, a fim de reduzir o conteúdo de água do tecido vegetal para promover uma melhor eficiência na combustão. Algumas árvores permaneceram em pé após a derrubada.

A queimada, na área do experimento, foi feita pelos trabalhadores da fazenda, no dia 10 de setembro, adotando-se os procedimento tradicionais na Amazônia, ou seja, ateando-se o fogo, através de uma tira de borracha (pneu) em chamas presa à extremidade de uma vara, nas bordas da área derrubada para que as chamas se encontrem no meio do terreno e maximize o efeito da queima. A queima começou por volta das 13:00hs, no horário mais quente do dia $\left(36^{\circ} \mathrm{C}\right)$, e durou três horas. Às $16: 00 \mathrm{~h}$ as chamas já haviam cessado, permanecendo a queima da biomassa, em sua maior parte, na forma de brasas.

\subsubsection{Método de colheita destrutiva (direto)}

Este método consistiu na pesagem total da fitomassa contida nas parcelas de amostragem e sua extrapolação em hectare para estimar a fitomassa da área inteiramente derrubada. As transformações da fitomassa decorrentes da queima, tais como, quantidade de carbono liberado, formação de carvão e a eficiência de combustão da fitomassa, foram analisadas comparando-se os estoques de carbono e biomassa antes e depois da queimada.

Desta maneira, adotou-se a seguinte metodologia empregada por Jennifer Robinson (Simonett et al., 1986 ${ }^{1}$ ): foram implantadas duas "estrelas" com quadras de colheita destrutiva (Figura 10), cada uma consistiu de seis raios, ou quadras, de 2 × $30 \mathrm{~m}$. Os raios emanam de um centro comum em ângulos de $60^{\circ}$ e iniciam a 10 metros do

\footnotetext{
' Simonett, D.S.; Robinson, J.M. \& Feanrside, P.M. Mass Transformations in Tropical forest Burning: Case study evaluations and extension to biome-scale estimates. 1986. 116p. (projeto proposto a National Science Foundation).
} 
ponto central. Cada raio foi subdividido em três subquadras de $2 \times 10 \mathrm{~m}$. As quadras usadas na etapa após a queima tiveram seus cantos marcados com vergalhões de ferro resistentes ao fogo para que pudessem ser reconhecidas depois da queimada. Metade das quadras em cada estrela foi colhida antes da queima e a outra depois. Os raios alternados de pré e pós-queima evitam a tendência de erro de orientação espacial sistemática das árvores derrubadas.

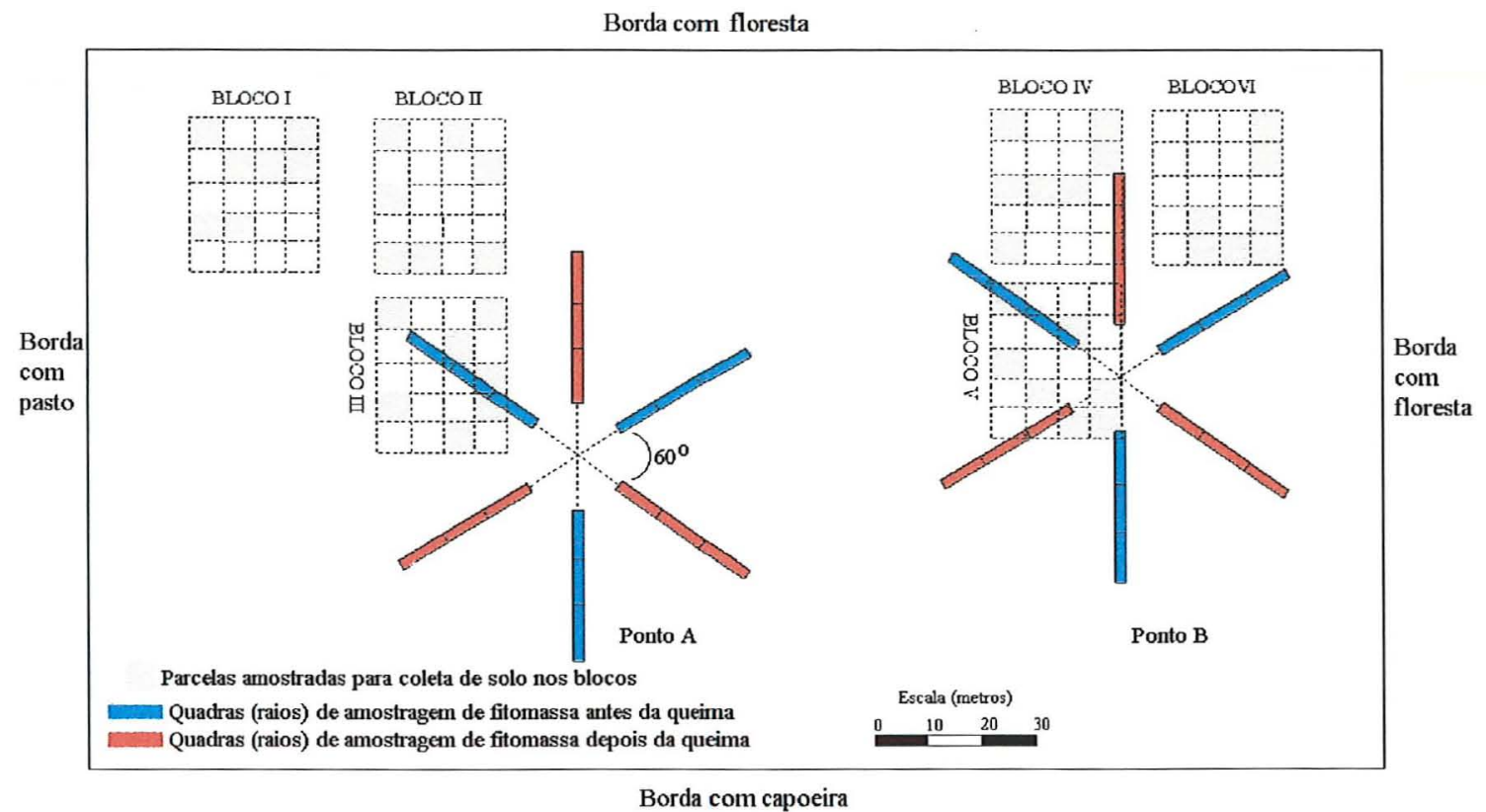

Figura 10 - Esquema da área experimental localizada na Fazenda Nova Vida em Ariquemes Rondônia.

A pesagem da fitomassa foi feita dentro de cada quadra. Toda a biomassa acima do nível do solo foi cortada com motosserra e facões (terçados), e pesada usando uma balança de mola com capacidade de $90 \mathrm{~kg}$, com precisão de $\pm 1 \mathrm{~kg}$. Após a pesagem, a biomassa foi reposta nas quadras para minimizar o efeito do enleiramento de material combustível na área a ser queimada, que poderia influenciar na qualidade da combustão. A fitomassa da fase antes da queima foi dividida em onze classes, conforme o tipo do material vegetal e a dimensão do diâmetro das peças amostradas : 
a) madeira com diâmetro $<5 \mathrm{~cm}$ : material lenhoso composto predominantemente de galhos e pequenos caules de arvoretas.

b) madeira com diâmetro entre 5 a $10 \mathrm{~cm}$ : material lenhoso composto de galhos e caules de arvoretas

c) madeira com diâmetro maior do que $10 \mathrm{~cm}$; consiste basicamente de galhos e troncos de árvores.

d) cipós com diâmetro $<5 \mathrm{~cm}$

e) cipós com diâmetro entre 5 a $10 \mathrm{~cm}$

f) cipós com diâmetro $\geq 10 \mathrm{~cm}$

g) serapilheira: composto basicamente pela serapilheira propriamente dita, incluído as folhas das copas. A folhas "verdes" não puderam ser coletas separadamente porque logo após a derrubada as folhas entram em processo de abscisão.

h) palmeiras com diâmetro $<10 \mathrm{~cm}$

i) palmeiras com diâmetro $\geq 10 \mathrm{~cm}$

j) folhas de palmeiras

1) Troncos podres $>10 \mathrm{~cm}$

As mesmas classes ou frações tiveram seus estoques avaliados após a queima. Além destas, foram incluídas as classes para carvão depositado sobre solo e carvão aderido à biomassa parcialmente carbonizada (para as mesma frações). $\mathrm{O}$ carvão sobre $\mathrm{o}$ solo foi coletado manualmente. Neste procedimento, colheu-se todos os fragmentos visíveis, examinando-se minunciosamente o chão, e utilizou-se uma peneira de malha de $5 \mathrm{~mm}$ de abertura para separar o carvão nos depósitos de cinzas. Uma certa quantidade de carvão de dimensões muito pequena não pôde ser separada, porém assume-se que este valor é proporcionalmente muito reduzido. Os carvões aderidos às frações de biomassa (troncos, galhos e cipós) foram raspados com facões. Como a carbonização no interior da madeira não queimada é gradual, esta operação pode ser aplicada. As partes carbonizadas foram removidas aplicando-se golpes de facão, com força moderada, em cada peça, o 
suficiente para remover a parte carbonizada de cor preta, porém deixando a madeira parcialmente carbonizada de cor amarronzada.

Os procedimentos utilizados no método destrutivo para a coleta das amostras de campo e para a determinação de parâmetros físicos e químicos da biomassa estão descritos nos sequintes itens:

\section{a) Coleta das amostras de biomassa e carvão}

As amostras de biomassa e de carvão foram retiradas do material vegetal contido nas sub-quadras $(2 \times 10 \mathrm{~m})$ dos raios $(30 \mathrm{~m})$ de cada "estrela". Para cada classe de biomassa e carvão foi separada uma amostra, pesada no campo, acondicionadas em sacos plásticos e rotuladas com a informação do tipo de material, sub-quadra e classe de diâmetro. Estas amostras foram tomadas ao acaso nas pilhas formadas pelos materiais que foram pesados nas quadras para cada tipo de material vegetal e classe de diâmetro, com exceção para a classe de diâmetro $\geq 10 \mathrm{~cm}$, que foi retirado um disco de cada peça de madeira.

\section{b) Coleta das amostras de cinzas}

No dia seguinte após a queima fez-se a amostragem das cinzas nos raios de pósqueima. As amostras das cinzas foram coletadas manualmente, cuidadosamente, usandose uma pá de plástico com auxilio de um pincel e acondicionadas em sacos plásticos, evitando-se a contaminação por agregados de argila, carvões e outros fragmentos vegetais (pedaços de folhas, gravetos, etc.). As cinzas foram coletadas ao longo do eixo central dos raios, numa área de $0,10 \times 10 \mathrm{~m}\left(1 \mathrm{~m}^{2}\right)$ por sub-quadra, antes do processo de corte e pesagem da biomassa das quadras. 


\section{c) Percentual de umidade das amostras vegetais}

Para a determinação da umidade, todas as amostras vegetais e derivados da queima foram secas a $60^{\circ} \mathrm{C}$ em estufas elétricas, com ventilação de ar forçada. A amostra foi considerada totalmente seca, quando seu peso tornou-se constante, após pesagens períodicas. O teor de umidade foi calculado, com base na massa da amostra seca, utilizando-se a seguinte equação (6):

$$
U \%=\frac{m u-m s}{m s} \cdot 100
$$

onde:

$U \%=$ Percentual de umidade da amostra;

$m u=$ massa da amostra úmida;

$m s=$ massa da amostra seca

O percentual de umidade das amostras foi calculado para estimar os estoques de fitomassa de cada classe, em relação a amostra seca, utilizando-se a seguinte equação (7), derivada a partir da equação (6):

$$
P S=\frac{P u \times 100}{U \%+100}
$$

onde:

$P S=$ peso do estoque de fitomassa seca;

$P u=$ peso do estoque de fitomassa úmido;

$U \%=$ percentual de umidade da amostra

\section{d) Densidade básica das amostras vegetais}

A densidade básica (massa da amostra seca / volume da amostra úmida) foi calculada pelo método de imersão, baseado na variação do peso da amostras. como descrito por Trugilho et al. (1987). Este também conhecido como método da balança 
hidrostática. baseia-se no princípio de Arquimedes, onde a perda aparente de peso de um corpo imerso em um líquido é igual ao peso do líquido deslocado (assumindo-se que a densidade da água é igual a um). A densidade básica foi determinada apenas para as amostras de madeira $\geq 10 \mathrm{~cm}$, amostras de carvão aderidas em madeira $\geq 10 \mathrm{~cm}$ de diâmetro e cascas. A obtenção das amostras para determinação da densidade da classe de madeira $\geq 10 \mathrm{~cm}$ foi feita retirando-se uma subamostra, em forma de cunha, 1/8 do disco das amostras de madeira contidos em cada sub-quadra. $O$ carvão foi subamostrado retirando-se cerca de $20 \mathrm{~g}$, ao acaso, do material amostrado e as cascas foram subamostradas retirando-se cerca de $5 \mathrm{~cm}$ de extensão da casca ao redor dos discos para cada disco de madeira $\geq 10$ coletado nas sub-quadras. As amostras para a determinação de densidade ficaram imersas em águas durante 30 dias, para sua completa saturação. As amostras de carvão, foram acondicionadas em telas de nylon (tipo filó) e as cunhas de madeira e casca em sacos de plástico em forma de malha (geralmente usados por feirantes para embalar laranjas) antes de serem imersos. Também foi determinado o peso seco de cada amostras, como descrito no ítem anterior. A densidade básica calculada para madeira $>10 \mathrm{~cm}$ de diâmetro, refere-se somente ao lenho, as cascas foram determinadas à parte como descrito acima. A determinação da densidade básica teve a finalidade de converter o volume de madeira obtidos por métodos indiretos em massa, e foi determinada pela equação (8) apresentada a seguir:

$$
D B=\frac{P a s}{P a m-P a i}
$$

onde:

$D B=$ densidade básica da amostra $\left(\mathrm{kg} \mathrm{m}^{-3}\right)$;

Pas = peso da amostra absolutamente seca $(\mathrm{g})$;

Pam = peso da amostra na máxima umidade $(\mathrm{g})$;

$P a i=$ peso da amostra imersa em água via balança hidrostática $(\mathrm{g})$;

Pam - Pai $=$ volume da amostra 


\section{e) Percentual de casca nas amostras de troncos e galhos $\geq 10 \mathrm{~cm}$}

A percentagem de casca nesta classe de biomassa foi estimada separando-se todas as cascas presentes nos discos amostrados dos troncos e galhos $\geq 10$. O percentual de casca foi determinado dividindo-se o peso de todas cascas contidas nas amostras pelo peso total (casca + lenho) das amostras, expresso em porcentagem multiplicando-se o resultado por cem. O percentual de casca foi calculado para cada uma das etapas antes de queimar e após a queima, uma vez que casca foi consumida pelo fogo. O percentual de casca teve por finalidade avaliar a quantidade de casca nos estoques biomassa estimados pelos métodos indiretos.

\section{f) Preparação das amostras vegetais para análise química}

As amostras, previamente secas, foram primeiramente picadas na forma de "palito" na sua totalidade, com exceção das amostras de madeira com diâmetro $\geq 10 \mathrm{~cm}$, de onde retirou-se uma sub-amostra, em forma de cunha, de 1/8 do disco coletado no campo, separando-se as cascas para serem analisadas a parte. O material vegetal picado foi homogeneizado e retirado uma subamostra para ser moido em moinho-esfera, tipo Wiley, com malha de $1 \mathrm{~mm}$ de abertura. Após a o processo de moagem. efetuou-se a análise química.

\section{g) Determinação do conteúdo de carbono das amostras}

O conteúdo de carbono das amostras vegetais e de solo foram determinados, através de digestão "via seca", pelo analisador de carbono LECO, modelo CR-412, no laboratório de Química do Solo, do Centro de Energia Nuclear na Agricultura (CENA/USP). A análise consiste em colocar a amostra num sistema de combustão (forno), que é um ambiente de oxigênio puro, regulado em $1350{ }^{\circ} \mathrm{C}$. Desta forma o carbono da amostra é completamente oxidado na forma de $\mathrm{CO}_{2}$. Os gases formados 
passam por dois tubos de Anidrona $\left(\mathrm{Mg}\left(\mathrm{ClO}_{4}\right)_{2}\right)$ para remover a umidade, através de um controlador de fluxo, até chegar nas células de deteç̧ão infra-vermelho. Estas células medem a concentração de dióxido de carbono presente no gás, depois o aparelho converte valores de $\mathrm{CO}_{2}$ em percentagem de carbono.

\subsubsection{Método de amostragem por interseção de linhas}

O método de amostragem por intersecção de linhas, adotado, foi desenvolvido por Van Wagner (1968), para avaliar o volume de madeira em áreas derrubadas. Neste estudo, este método foi aplicado para estimar o volume de todas as peças de madeira com diâmetro $\geq 10 \mathrm{~cm}$ antes e depois da queimada, sendo adaptado para estimar a formação de carvão. Desta maneira, possibilitou calcular o percentual de biomassa consumido pela queima para esta classe de biomassa.

Este método baseia-se na teoria de que uma suposta linha de amostragem de comprimento $L$ atravessa uma área contendo vários cilindros horizontais de diversos comprimentos, diâmetros e orientações. A linha de amostragem irá cruzar os cilindros em vários ângulos, fazendo uma série de seções elípticas atravessadas verticalmente, que, se somadas, podem prover a estimativa requerida de volume. Para visualização deve-se imaginar uma linha de comprimento infinitesimal, que anula a divisão do volume total pela área total do terreno amostrado. Assim, pode-se estabelecer o volume por unidade de área, em termos de área seccionalmente cruzada pelo comprimento da linha. Supondose que todas as possiveis orientações são igualmente representadas através da área amostrada e que o número de interseções é estatísticamente grande, então, seja qual for seu ângulo real de cruzamento, espera-se que cada interseção apresente uma área seccional que é a soma de todas as possíveis áreas elípticas. Cada uma destas áreas elípticas será ponderada por sua fração de probabilidade, e dependerá apenas do diâmetro da peça.

O volume de madeira por este método é obtido pela seguinte equação (9): 


$$
V=\frac{\pi^{2} \sum d^{2}}{8 L}
$$

onde:

$$
\begin{aligned}
& V=\text { volume de madeira por unidade de área; } \\
& d=\text { diâmetro da peça; } \\
& L=\text { comprimento da linha de amostragem }
\end{aligned}
$$

As linhas de amostragem por intercepção foram implantadas, após a derrubada, ao longo do eixo central de cada raio nas parcelas do método destrutivo, da fase pósqueima, antes e depois da queima. Utilizou-se as regras de decisão descrita por Van Wagner (1968) para inclusão das peças interceptadas pela linha de amostragem.

A circunferência das peças de madeira foi medida em ângulo reto ao eixo de cada peça. Tarjas de alumínio numeradas foram pregadas em cada peça no ponto de medida, possibilitando a repetição da medida no mesmo lugar e a identificação de cada peça. A possibilidade de avaliar o volume antes e depois da queima para as mesmas peças reduz ao mínimo o efeito da variação espacial da biomassa.

Fez-se, também medições da espessura de carvão nas quadras de pós-queima ao redor da circunferência das peças $\geq 10 \mathrm{~cm}$ interceptadas pela linha de amostragem. As medidas foram tomadas em dez pontos, ao acaso, ao redor da circunferência das peças. Para cada medida, foi feita uma incisão perpendicular ao eixo da peça de madeira usandose um facão. A espessura da camada de carvão formada nas peças foi, então, medida com o auxílio de uma régua plástica transparente calibrada em milímetros.

\section{a) Cálculo da formação de carvão aderido nas peças de madeira com diâmetro $\geq 10$ cm}

A quantidade de carvão aderido nos troncos e galhos com diâmetro $\geq 10 \mathrm{~cm}$ foi calculada subtraindo-se o volume total de madeira, estimado depois de queimar para cada 
quadra (raio da "estrela" de $2 \times 30 \mathrm{~m}$ ), do volume de madeira sem carvão. O volume de madeira sem carvão foi calculado a partir da subtração do diâmetro de cada peça de madeira da espessura formada pela camada de carvão.

\section{b) Percentual de consumo de biomassa para peças de madeira $\geq 10 \mathrm{~cm}$ pela queima}

O percentual de consumo foi calculado pela diferença da fitomassa nas etapas antes e depois da queima, pela conversão do volume de madeira $\geq 10 \mathrm{~cm}$ em massa, aplicando as seguintes transformações para cada fase.

$\mathrm{Na}$ etapa antes da queima, o primeiro passo foi estimar o percentual de volume de casca do volume total das quadras $(2 \times 30 \mathrm{~m})$. Este foi obtido, inicialmente, convertendose o volume médio total $\left(\mathrm{m}^{3} \mathrm{ha}^{-1}\right)$ em massa $\left(\mathrm{t} \mathrm{ha}{ }^{-1}\right)$, a partir da densidade de lenho para cada raio. Então, em seguida, estimou-se o estoque de casca $\left(t \mathrm{tha}^{-1}\right)$ da biomassa através do percentual de casca obtido para as amostras de madeira $\geq 10 \mathrm{~cm}$. Este estoque de casca em massa foi convertido em volume pela sua densidade média. Finalmente, dividiuse o estoque de volume de casca pelo volume total médio de madeira $\geq 10 \mathrm{~cm}$, obtendo-se o percentual de volume de casca.

O segundo passo foi converter o volume total em massa para as duas frações: casca e lenho. Isto foi feito diminuindo-se o volume total de cada raio da percentagem de volume de casca, obtendo-se o volume de lenho. Este foi convertido em massa pela densidade do lenho e somado ao volume de casca convertido em massa, para obter-se a biomassa total de cada quadra.

$\mathrm{Na}$ segunda etapa, para obter-se a biomassa de cada quadra depois de queimar (pós-queima), calculou-se, inicialmente, o percentual de volume de casca, da mesma maneira, como descrito anteriormente para fase antes da queima. A partir do percentual de volume de casca e da estimativa do volume de carvão pôde-se calcular o volume de lenho do volume total. O volume de lenho foi obtido subtraindo o volume total das frações de volume de casca e de carvão. $\mathrm{E}$, finalmente, depois de calculado o volume de 
cada fração. converteu-se o volume em massa para cada quadra, pelas respectivas densidades.

\subsubsection{Modificações no estoque de carbono no solo após a queima}

As modificações no estoque de carbono no solo foram acompanhadas através de coletas periódicas de solo desde a etapa da derrubada e queima da floresta até os meses iniciais da implantação da pastagem. completando um periodo de um ano.

As amostras de solo foram retiradas de seis blocos casualizados localizados dentro da área amostral a ser queimada (Figura 10) subdivididos em 20 parcelas de $6 \times 6$ m. As amostras foram coletadas em mini-trincheiras, ao acaso, em quatro profundidades diferentes: $0-5 \mathrm{~cm}, 5-10 \mathrm{~cm}, 10-20 \mathrm{~cm}$ e $20-30 \mathrm{~cm}$, para cada uma das parcelas dos seis blocos. As amostras foram coletadas na área alterada 72 dias após a derrubada (06/09/94), 2 dias após a queima (12/09/94), 29 dias após a queima (09/10/94), 58 dias após a queima (07/11/94), 85 dias após a queima (04/12/94), 12 dias após a introdução da pastagem (16/2/95) e a última coleta, 364 dias após a $1^{\underline{a}}$ coleta (6/09/95), ou 436 dias após a derrubada. Foram, também, coletadas amostras do solo da floresta não pertubada, nas mesmas datas, seguindo a mesma metodologia, que serviram de controle (testemunha).

As amostras de solo foram secas ao ar livre em bandejas, depois destorroadas, separadas as raizes e passadas em peneira com malha de $2 \mathrm{~mm}$ de abertura. Após homogeneização do solo foi retirada uma parte da amostra para ser triturada e passada inteiramente por peneira de $0,15 \mathrm{~mm}(100 \mathrm{mesh})$. As alíquotas das amostras foram acondicionadas em frascos de plático, devidamente etiquetados, e posteriomente submetidos a análise química, para a determinação do carbono. $\mathrm{O}$ aparelho utilizado foi o analisador de carbono LECO, modelo CR-412L, o mesmo empregado para a análise do tecido vegetal. 


\section{c) Densidade do solo}

As amostras de solo para análise de densidade foram coletadas pelo método do cilindro volumétrico conforme Anderson \& Ingran (1993), tomando-se como padrão um cilindro de volume conhecido. As amostras foram secas a $105^{\circ} \mathrm{C}$ e a densidade do solo foi calculada de acordo com a fórmula:

$$
\text { Densidade do solo }\left(\mathrm{g} \mathrm{cm}^{-3}\right)=\frac{\text { massa do solo seca }\left(105^{\circ} \mathrm{C}\right)}{\text { volume do cilindro }}
$$

\section{d) Cálculo para estimar o estoque total de carbono no solo}

O estoque total de carbono, considerado até $30 \mathrm{~cm}$ de profundidade, foi obtido somando-se o estoque de carbono para cada camada amostrada. $O$ estoque para as camadas foi calculado multiplicando os teores de carbono total (\%) pela densidade do solo $\left(\mathrm{t} \mathrm{m}^{-3}\right)$ e pela espessura de cada camada $(\mathrm{m})$.

\section{e) Delineamento experimental e análise estatística dos dados de solo}

Os dados de solo foram analisados considerando-se cada sistema (alterado e floresta original) como experimentos distintos. O delineamento experimental adotado foi o de blocos ao acaso com seis repetições, considerando-se como tratamento principal as sete épocas de amostragem. Avaliou-se conjuntamente os experimentos através da análise de grupos de experimentos, tendo como causas de variação, a interação entre as épocas, as profundidades e os locais dos experimentos. As médias obtidas foram submetidas a análise de variância, teste F e Tukey através do "software" STATISTICA/ w5.0 for windows ${ }^{1}$.

\footnotetext{
${ }^{1}$ Programa computacional desenvolvido pela StatSoft, Inc. (1996). STATISTICA for Windows [Computer program manual]. StatSoft, Inc, Tulsa, OK.
} 


\section{RESULTADOS E DISCUSSÃO}

Neste tópico pretende-se analisar a importância da fitomassa da Amazônia em relação ao seu potencial de liberação de carbono para a atmosfera através das queimadas. Para estimar o estoque de carbono da fitomassa presente em cada tipo de formação vegetal, elaborou-se um mapa de vegetação da Amazônia Legal, em formato digital, onde foram estimadas as áreas ocupadas por elas. A fitomassa presente nestas áreas foram estimadas, criando-se um de banco de dados com base em mais de 2700 dados de volume de madeira, publicados nos levantamentos de recursos naturais elaborados pelo Projeto RADAMBRASIL (1973-1983). Os dados de tipos de vegetação não levantados pelo RADAMBRASIL, foram obtidos a partir de pequenos levantamentos isolados, geralmente, de interesse ecológico feitos na Amazônia, ou em outras regiões tropicais. Desta forma, pode-se calcular o potencial de carbono estocado na fitomassa para cada tipo de vegetação na Amazônia Legal.

As transformações e a liberação de carbono que ocorrem na fitomassa pela prática da queimada foram avaliadas através de um estudo de caso na Fazenda Nova Vida, em Ariquemes, RO. Neste estudo foram feitas medições da biomassa antes e depois da queima, que serviram para calcular parâmetros de grande importância na quantificação da emissão de carbono, tais como formação de carvão e cinzas, e o coeficiente de combustão.

Os resultados obtidos serão discutidos, comentando-se a respeito de outros trabalhos já realizados na Amazônia, e servirão para estimar a quantidade aproximada de carbono que já foi emitida pela queima inicial da fitomassa florestal, sem considerar as possíveis requeimas, e a sua contribuição anual. 


\subsection{Interpretação e medição das áreas de vegetação Amazônia Legal}

O mapa, representado na Figura 11, mostra as áreas ocupadas por cada um dos tipos de vegetação. As florestas foram o tipo de vegetação predominante na Amazônia. A área coberta pelas florestas representou cerca de $74 \%\left(3,7 \times 10^{6} \mathrm{~km}^{2}\right)$ da área total (incluindo rios e áreas alagadas por represas de hidrelétricas) da Amazônia Legal. As florestas densas representraram $53,0 \%$ do total da cobertura florestal, cobrindo uma área de $1,96 \times 10^{6} \mathrm{~km}^{2}$, seguido pelas florestas abertas com $23,8 \%\left(0,88 \times 10^{6} \mathrm{~km}^{2}\right)$ e por último os outros tipos de floresta não densa abrangendo cerca de $23,2 \%\left(0,86 \times 10^{6}\right.$ $\left.\mathrm{km}^{2}\right)$.

Os tipos não florestais cobriram uma área de $1,2 \times 10^{6} \mathrm{~km}^{2}$, ou seja $24,2 \%$ da área da Amazônia Legal, sendo que as savanas (cerrados) representaram 52,6\% desta, e os outros tipos não florestais apenas $8,3 \%$. As áreas antrópicas cobriram cerca de $39,0 \%$ da extensão dos tipos não florestais e representaram uma área de 472.529,2 km². Esta área representa todas as alterações na cobertura vegetal original da Amazônia Legal, incluindo as áreas derrubadas de florestas e cerrados para o ano de 1988, data em que alterações da cobertura vegetal foram atualizadas no mapa da SUDAM/IBGE (1989). Infelizmente não existe um mapa mais atualizado para Amazônia Legal disponível, no nível de detalhamento do mapa utilizado aqui.

Os valores para a cobertura florestal são semelhantes àqueles encontrados por Fearnside (1992a) de 3,7 x 10 $0^{6} \mathrm{~km}^{2}$, e corresponde a 74\% da Amazônia Legal. Fearnside (1992a), também encontrou uma área de $1,94 \times 10^{6} \mathrm{~km}^{2}$ para florestas densas e $1,79 \mathrm{x}$ $10^{6} \mathrm{~km}^{2}$ para florestas não densas (inclusive florestas abertas) bem próximos aos encontrados aqui. Estes valores foram obtidos a partir do mapa elaborado pelo Instituto Brasileiro de Geografia e Estatística (IBGE) e o Instituto Brasileiro de Desenvolvimento Florestal (IBDF), em 1988, numa escala mais grosseira de 1: 5.000.000, digitalizado e analisado por Fearnside \& Ferraz (1995). 
Araújo et al. (1986), mencionaram uma área ocupada por florestas ombrófilas (inclui florestas densas e abertas) de $3,1 \times 10^{6} \mathrm{~km}^{2}$, que representou $61,65 \%$ da Amazônia Legal. Esta área é um menor do que a área de $3,4 \times 10^{6} \mathrm{~km}^{2}$ encontrada aqui para florestas ombrófilas (incluindo as áreas de tensão ecológica). As diferenças nas estimativas de áreas de cobertura vegetal podem estar relacionadas a vários fatores, tais como origens e datas diferentes do mapa em que foi baseada a estimativa, escala do mapa, e inclusão ou não de superficies de água de barragens de hidrelétricas.

\subsection{Biomassa e estoque de carbono da vegetação florestal na Amazônia}

As estimativas da biomassa e do estoque de carbono estão apresentados na Tabela 6. A biomassa total média, de todos os tipos florestais, ponderada pela área ocupada por cada categoria de floresta foi de $422 \mathrm{t} \mathrm{ha}^{-1}$. A biomassa total média para as florestas densas foi de $430 \mathrm{t} \mathrm{ha}^{-1}$, um pouco mais alta do que a floresta aberta de $422 \mathrm{t} \mathrm{ha}^{-1}$. Os outros tipos de florestas não densas, estimados em $405 \mathrm{t} \mathrm{ha}^{-1}$, foi a categoria que apresentou a menor biomassa média. Apesar destas florestas possuirem características florísticas e estruturais distintas, observou-se pouca diferença em relação à biomassa. Brown, et al., (1995) verificaram ser comum encontrar na literatura estimativas para biomassa de florestas abertas maiores do que para florestas densas. Esta aparente contradição possivelmente pode estar relacionada aos métodos empregados nas estimativas e provavelmente a maior presença de árvores de maiores dimensões em florestas abertas do que em florestas densas, que compensariam a distribuição mais esparsas das árvores em florestas abertas. 
Tabela 6. Biomassa, estoques de carbono e número de amostras levantadas em áreas de florestas presentes na Amazônia Legal.

\begin{tabular}{|c|c|c|c|c|c|}
\hline Código (1) & Área & Biomassa total & $\begin{array}{c}\text { Número de } \\
\text { parcelas (1 ha) }\end{array}$ & $\begin{array}{l}\text { Biomassa média } \\
\text { (ponderada pela área) }\end{array}$ & $\begin{array}{c}\text { Estoque de } \\
\text { carbono }\end{array}$ \\
\hline & $\mathrm{km}^{2}$ & $\mathrm{tha}^{-1}$ & & $\mathrm{tha}^{-1}$ & $10^{6} \mathrm{t}$ \\
\hline \multicolumn{6}{|c|}{ Floresta densa } \\
\hline $\mathrm{Da}$ & $382.560,2$ & 419 & 387 & & $8.015,7$ \\
\hline $\mathrm{Db}$ & $761.493,6$ & 432 & 477 & & $16.439,5$ \\
\hline $\mathrm{Dm}$ & $36.881,3$ & 404 & 32 & & 744,1 \\
\hline Ds & $782.515,9$ & 434 & 531 & & $16.968,1$ \\
\hline Subtotal & $1.963 .451,1$ & & 1.427 & 430 & $42.167,3$ \\
\hline \multicolumn{6}{|c|}{ Floresta aberta } \\
\hline $\mathrm{Ab}$ & $345.926,2$ & 447 & 197 & & $7.736,6$ \\
\hline As & $534.152,2$ & 406 & 681 & & $10.847,7$ \\
\hline Subtotal & $880.078,4$ & & 878 & 422 & $18.584,3$ \\
\hline \multicolumn{6}{|c|}{ Outras não densa } \\
\hline $\mathrm{Fa}$ & $15.590,7$ & 343 & 7 & & 267,3 \\
\hline $\mathrm{Fb}$ & $7.092,1$ & 381 & 10 & & 135,1 \\
\hline Fs & $21.193,7$ & 458 & 16 & & 485,6 \\
\hline $\mathrm{Cs}$ & $9.065,3$ & 435 & 1 & & 197,1 \\
\hline Là & $19.249,1$ & 310 & 4 & & 298,2 \\
\hline $\mathrm{Ld}$ & $65.221,3$ & 365 & 26 & & $1.189,5$ \\
\hline Lo & $17.6942,5$ & 463 & 205 & & $4.097,3$ \\
\hline On & $17.6751,6$ & 374 & 109 & & $3.752,9$ \\
\hline $\mathrm{Pf}$ & $6.149,5$ & 262 & (2) & & 80,6 \\
\hline So & $134.565,6$ & 425 & 58 & & $2.857,2$ \\
\hline $\mathrm{Sn}$ & $224.073,1$ & 354 & 38 & & $3.970,4$ \\
\hline $\operatorname{Tn}$ & 349,5 & 354 & (3) & & 6,2 \\
\hline Subtotal & $856.244,0$ & & 474 & 405 & $17.337,4$ \\
\hline Total & $3.699 .773,5$ & & 2779 & 422 & $78.089,1$ \\
\hline
\end{tabular}

1) Veja o significado de cada código na Tabela 3.

2) O volume de madeira para este tipo florestal não foi levantado pelo RADAMBRASIL. Sua biomassa foi estimada baseando-se no valor médio da biomassa aérea de mangues (128 t/ha), de dois estudos feitos por Golley et al. $(1966 ; 1968)$, na América Central. A biomassa subterrânea foi estimada considerando-se a relação de 0,64 entre raíz/caule (Olson, 1985).

(3) Não exite dados disponiveis na literatura quantificando a biomassa deste tipo de vegetação. Assumiuse que, devido a semelhança de vegetação, o valor de biomassa do tipo Sn. 
Considerando-se somente a biomassa da parte aérea viva para todos os tipos de florestas, a média estimada foi de $304 \mathrm{t} \mathrm{ha}^{-1}$. Esta média foi maior do que a média calculada para as florestas densas na Amazônia de $227 \mathrm{t} \mathrm{ha}^{-1}$, feita por Brown \& Lugo (1992), com base nos dados do RADAMBRASIL. Isto, em parte, é explicado pelos ajustes para acima de $28 \%$, adotados neste estudo para biomassa aérea, conforme foi empregado por Fearnside (1994) para corrigir as estimativas feitas por Brown \& Lugo (1992). Uma crítica mais abrangente às estimativas feitas por Brown \& Lugo (1992) pode ser vista em Fearnside (1992b).

Böhrer \& Campos (1993) estimaram a biomassa florestal aérea média (não ponderada) da Amazônia Legal em $285 \mathrm{t} \mathrm{ha}^{-1}$. Estes autores utilizaram as mesmas equações desenvolvidas por Brown \& Lugo (1992) para estimar a biomassa aérea de florestas ombrófilas densas e aberta, com base apenas nos dados do Projeto Radambrasil. Alguns fatores de ajustes adotados por Fearnside (1992), também foram utilizados para corrigir o DAP mínimo, o fator de forma e a densidade de casca e o alburno. Este valor está mais próximo daquele encontrado neste estudo. Entretanto, deve-se considerar que em termos de avaliar as emissões de carbono devido ao desmatamento, em decorrência de mudanças no uso da terra, é necessário que seja estimado a biomassa total da vegetação (incluindo todos os compartimentos da biomassa vegetal acima e abaixo do solo).

$\mathrm{O}$ valor encontrado de $420 \mathrm{tha} \mathrm{ha}^{-1}$ para a estimativa da biomassa total, foi bastante próxima das $428 \mathrm{t} \mathrm{ha}^{-1}$ estimado por Fearnside (1994). A causa principal para isto pode estar no fato de que esta estimativa foi baseada nos mesmos ajustes adotados por Fearnside (1994), para calcular a biomassa total da floresta. Estas estimativas, entretanto, consideram as florestas como sendo não pertubadas. Os levantamentos florestais da FAO e do RADAMBRASIL foram feitos em uma época onde a exploração florestal era pouco acentuada. Portanto estas estimativas referem-se a uma fase pré-exploração madeireira, já que não foi levado em conta a retirada de madeira. Fearnside (1994) relatou que nos anos 70 , os desmatamentos normalmente referiam-se à queima de floresta derrubada da qual nenhuma madeira tinha sido removida. A partir da melhoria das vias de acesso e com o 
aumento do preço da madeira, tornou-se uma prática comum a remoção de qualquer tipo de madeira comercializável, antes da derrubada, nos anos 90 .

O estoque de carbono presente na fitomassa florestal da Amazônia, tendo como base as áreas florestadas do mapa SUDAM/IBGE (1989), foi de $78 \mathrm{Pg}\left(1 \mathrm{Pg}=10^{15} \mathrm{~g}\right)$. Este valor indica o potencial de carbono acumulado na biomassa da floresta que pode ser liberado na forma de $\mathrm{CO}_{2}$ para a atmosfera pelos desmatamentos. Deste total as florestas densas contribuiram com $42 \mathrm{Pg}$, cerca de $54 \%$.

Schroeder \& Winjum (1995) estimaram um estoque inferior a este para florestas tropicais úmidas no Brasil, ocupando uma área de $3,5 \times 10^{6} \mathrm{~km}^{2}$, variando de 70 a $50 \mathrm{Pg}$ de carbono. Porém deve-se considerar que a estimativa das áreas de vegetação foi feita em um mapa baseado em imagens de satélite com resolução de $1,1 \mathrm{~km}$, mais apropriado para análises em escala continental, portanto com um nível de detalhamento muito mais grosseiro do que o utilizado neste mapa. Se considerarmos as estimativas de Fearnside (1994), para a biomassa originalmente presente na Amazônia, de $428 \mathrm{t} \mathrm{ha}^{-1}$ e a área estimada de florestas em Fearnside $\left(1992\right.$, b), para 1988 , de $3,7 \mathrm{~km}^{2}$, obtem-se um valor de $79 \mathrm{Pg}$ de carbono, muito próximo ao encontrado aqui.

\subsection{Biomassa e estoque de carbono da vegetação com formação não florestal}

A biomassa e o estoque de carbono para formações não florestais estão apresentados na Tabela 7.

Praticamente não existem estimativas para formações não florestais na Amazônia. A única estimativa para savanas (cerrados) na Amazônia foi publicada por Fearnside (1992a, 1994), que considerou a biomassa para todos os tipo não florestais, semelhantes

aos das savanas. Nestes estudos, Fearnside estimou uma biomassa média de $45 \mathrm{t}^{-1}$ para savanas, a partir de levantamentos de volume de lenha para carvão em Carajás, feito pela Companhia Vale do Rio Doce (CVRD), e em Mato Grosso, pelo Projeto RADAMBRASIL. Este valor é aproximadamente $60 \%$ maior do que a biomassa total média para savanas, de $28,4 \mathrm{t} \mathrm{ha}^{-1}$, encontrado aqui. 
Tabela 7. Biomassa e estoque de carbono da vegetação não florestal na Amazônia

\begin{tabular}{|c|c|c|c|c|}
\hline Código & Área & Biomassa total & $\begin{array}{c}\text { Biomassa média } \\
\text { ponderada pela área }\end{array}$ & $\begin{array}{l}\begin{array}{c}\text { Estoque de } \\
\text { carbono }\end{array}\end{array}$ \\
\hline & $\mathrm{km}^{2}$ & $\mathrm{tha}^{-1}$ & tha $^{-1}$ & $10^{6} \mathrm{t}$ \\
\hline \multicolumn{5}{|c|}{ Savanas (Cerrados) } \\
\hline $\mathrm{Sa}(1)$ & $364.505,5$ & 33,56 & & 611,6 \\
\hline $\operatorname{Sd}(1)$ & $47.268,9$ & 60,16 & & 142,2 \\
\hline $\operatorname{Sg}(2)$ & $34.532,3$ & 11,41 & & 19,7 \\
\hline $\mathrm{Sp}(2)$ & $171.756,6$ & 11,71 & & 100,6 \\
\hline $\operatorname{St}(1)$ & $8.040,0$ & 46,86 & & 18,8 \\
\hline $\mathrm{Ta}(1)$ & 167,6 & 33,56 & & 0,3 \\
\hline $\mathrm{Td}(1)$ & $2.323,5$ & 60,16 & & 7,0 \\
\hline $\operatorname{Tp}(2)$ & $9.612,5$ & 11,71 & & 5,6 \\
\hline Subtotal & $638.206,9$ & & 28,4 & 905,8 \\
\hline \multicolumn{5}{|c|}{ Outras não florestais } \\
\hline $\mathrm{Pa}(3)$ & $81.592,22$ & 66,7 & & 244,9 \\
\hline $\operatorname{Lg}(4)$ & $19.025,11$ & 46 & & 43,8 \\
\hline $\operatorname{Rm}(5)$ & 966,66 & 22,2 & & 1,0 \\
\hline Subtotal & $101.584,0$ & & 62,4 & 289,6 \\
\hline \multicolumn{5}{|c|}{ Áreas Antrópicas } \\
\hline $\mathrm{AA}(6)$ & $472.529,2$ & 43,5 & & 925,0 \\
\hline Subtotal & $472.529,2$ & & 43,5 & 925,0 \\
\hline $\begin{array}{l}\text { Todas as } \\
\text { categorias }\end{array}$ & $1.212 .320,1$ & & 37,1 & 2120,5 \\
\hline
\end{tabular}

(1) Tipos vegetacionais estimados a partir de dados do RADAMBRASIL. Os valores para Td e Ta foram extrapolados a partir dos valores estimados, respectivamente, de Sd e Sa. O tipo ST foi estimado a partir da média entre Sd e Sa.

(2) $\mathrm{Sp} \mathrm{e} \mathrm{Sg} \mathrm{foram} \mathrm{estimados,} \mathrm{respectivamente,} \mathrm{a} \mathrm{partir} \mathrm{dos} \mathrm{valores} \mathrm{de} \mathrm{biomassa} \mathrm{aérea} \mathrm{de} \mathrm{campo} \mathrm{sujo} \mathrm{e}$ campo limpo encontrados por Kauffman et al. (1994), para região de cerrado próxima à Brasília. O valor encontrado para $\mathrm{Sp}$ foi extrapolado para o tipo $\mathrm{Tp}$. A biomassa de raízes foi estimada assumindose o valor de 1,6 para a razão raiz/caule adotado por Schroeder \& Winjum (1995) para a classe de vegetação savana/campo (savanna/grassland).

(3) O valor de biomassa total para Pa foi retirado de Olson et al. (1983) para áreas pantanosas (wetlands) nos trópicos, assumindo o valor médio de conteúdo de carbono de 0,45 .

(4) Lg foi estimado a partir do valores de biomassa aérea para campina (bana), para a região de San Carlos de Rio Negro, Venezuela, de Kauffman et al. (1988) e biomassa subterrânea de campina, para região próxima de Manaus, de Klinge (1975).

(5) O valor de biomassa total para $\mathrm{Rm}$ foi retirado de Olson et al. (1983) para áreas de vegetação gramíneo-lenhosa de complexos montanhosos nos trópicos (tropical montane complexes), assumindo o valor médio de conteúdo de carbono de 0,45 .

(6) A biomassa média ponderada pela área foi estimada a partir dos valores percentuais das áreas de cada tipo de uso da terra, estimados por Fearnside \& Guimarães (1996) para o ano de 1990. 
Uma das grandes razões para essa discrepância, pode estar nas áreas de savana parque e gramíneo-lenhosa que não foram computadas na sua estimativa, uma vez que não foram incluídos nos levantamentos pela CVRD e pelo RADAMBRASIL. Esses tipos de vegetação, composta em sua maior parte por gramíneas, apresentam uma biomassa muito mais baixa do que as savanas abertas e densas. Além disso as savanas parque e gramíneo-lenhosa (incluindo Tp, savana estépica parque) representam cerca de $34 \%$ da área ocupada por savanas (cerrados) na Amazônia Legal.

A biomassa média para a categoria de outros tipos não florestais foi estimada em $62,4 \mathrm{t} \mathrm{ha}^{-1}$. Apesar de possuirem uma biomassa vegetal superior em relação às savanas, sua área é muito reduzida, contribuindo muito pouco para o estoque potencial de carbono na Amazônia.

As áreas antrópicas poderiam ser consideradas a parte por não serem sistemas naturais, mas como geralmente os tipos vegetacionais predominantes nestas áreas não são florestais, elas foram analisadas juntamente com as categorias anteriores. Sua biomassa total foi de 43,5 $\mathrm{t} \mathrm{ha}^{-1}$, conforme estimado por Fearnside \& Guimarães (1996).

O estoque de carbono total, para todas as categorias não florestais foi de $2,1 \mathrm{Pg}$. Esta contribuição para o potencial de carbono na fitomassa da Amazônia é insignificante se compararmos aos $78 \mathrm{Pg}$ estocados na formação florestal. Desta maneira, o menor grau de confiabilidade das estimativas para os tipos não florestais (com poucos dados disponíveis na literatura) é compensada pela sua reduzida participação no estoque total de carbono da Amazônia.

O estoque total para todos os tipos de vegetação presentes na Amazônia de 80,1 $\mathrm{Pg}$, representou $14 \%$ do estoque total global de carbono da vegetação de $594 \mathrm{Pg}$ (Houghton, 1994). Portanto, o potencial de emissão de carbono para a atmosfera é significativo, caso os desmatamentos na Amazônia continuem indefinitivamente. 


\subsection{Estimativa e transformações da fitomassa na área estudada na Fazenda Nova Vida (RO)}

\subsubsection{Estimativa da biomassa florestal em pé acima do solo antes da queima}

A estimativa da biomassa aérea das árvores em pé e outros dados obtidos pelo levantamento florestal realizado na área de amostragem de 1 ha, antes do corte e queima da floresta, estão apresentados na Tabela 8.

Tabela 8. Dados obtidos no levantamento florestal de 1 ha.

\begin{tabular}{|c|c|c|}
\hline Parâmetro (1) & Valor & C.V. \\
\hline $\begin{array}{l}\text { Biomassa aérea total das } \\
\text { árvores em pé }\left(\mathrm{t} \mathrm{ha}^{-1}\right)\end{array}$ & 204,5 & $58,79(4)$ \\
\hline Área basal $\left(\mathrm{m}^{2}\right)$ & 21,79 & - \\
\hline Altura média (m) & 15,0 & 27,73 \\
\hline DAP médio $(\mathrm{cm})$ & 22,72 & 63,04 \\
\hline $\mathrm{N}^{\mathrm{o}}$ total de indivíduos & 418 & - \\
\hline Árvores intactas & 364 & - \\
\hline Árvores defeituosas (2) & 21 & - \\
\hline $\mathrm{N}^{0}$ de palmeiras (3) & 33 & - \\
\hline \multicolumn{3}{|c|}{$\begin{array}{l}\text { (1) Não foram incluidas as palmeiras nas estimativas de biomassa total, área basal, altura média e DAP } \\
\text { médio. } \\
\text { (2) Foram consideradas como defeituosas árvores ocas, podres e com a copa quebrada (sem copa). Destas, } \\
\text { três estavam ocas; uma podre inteira; doze podres e sem copa; e cinco vivas sem copa. } \\
\text { (3) As palmeira foram incluídas no número total de indivíduos. } \\
\text { (4) Calculado subdividindo-se a área total ( } 1 \text { ha) em } 25 \text { subparcelas de } 400 \mathrm{~m}^{2}(20 \times 20 \mathrm{~m}) \text {. } \\
\text { C.V. = coeficiente de variação }(\%)\end{array}$} \\
\hline
\end{tabular}

A biomassa estimada pelo método indireto foi de $204,5 \mathrm{tha}^{-1}$, baseada na medição de 385 árvores presentes na área amostrada, excluindo-se a biomassa das palmeiras. Este valor foi menor do que aquele encontrado por Brown, et al. (1995), que 
estimaram a biomassa aérea em $285 \mathrm{t} \mathrm{ha}^{-1}$, a partir da medição de 474 árvores, para este mesmo tipo de floresta.

Estimativas diferentes para um mesmo tipo de floresta não é incomum na Amazônia. A alta variabilidade entre as florestas, mesmo dentro de um mesmo tipo de floresta, tem sido citada por alguns autores. Por exemplo, Hougthon (1994) afirmou que tipos diferentes de florestas estocam diferentes quantidades de carbono dentro de sua biomassa, e que locais diferentes dentro de um mesmo tipo de floresta também variam muito em relação à biomassa. Estes fatos invariavelmente resultam em diferentes estimativas de biomassa. Porém, vários fatores, tais como, critérios diferentes na inclusão dos compartimentos de biomassa da floresta e a retirada de madeira anterior aos levantamentos, também, contribuem para as diferenças entres as estimativas de biomassa.

$\mathrm{O}$ critério de não incluir a biomassa de palmeiras nas estimativas pode contribuir para a subestimativa dos resultados. As palmeiras frequentemente são excluidas dos levantamentos florestais, por serem consideradas sem valor econômico para fins madeireiros (Brown \& Lugo, 1992). No entanto. para estudos relacionados com a quantificação do carbono na fitomassa este compartimento não deveria ser desprezado. Fearnside (1992b) cita que a abundância de palmeiras varia grandemente nas florestas amazônicas, podendo representar entre $0,3 \%$ a $6,7 \%$ do total da biomassa aérea. Neste levantamento foram encontradas 33 palmeiras maiores do que $10 \mathrm{~cm}$ de diâmetro que resultaram em uma área basal de $1,6 \mathrm{~m}^{2} \mathrm{ha}^{-1}$. O estoque da biomassa de palmeiras foi estimado pelo método direto que será analisado adiante.

A retirada de madeira é outro fator que poderia afetar as estimativas, principalmente em regiões recém-colonizadas na Amazônia onde há uma forte pressão antrópica sobre os recursos naturais, como é o caso de Ariquemes.

Higuchi et al, (1994) estimando a biomassa de florestas densas em regiões de recente colonização na Amazônia, encontraram um valor para a fitomassa aérea de $185 \mathrm{t}$ $\mathrm{ha}^{-1}$ no sul do Pará e $228 \mathrm{t}_{\text {ha }} \mathrm{a}^{-1}$ no sul de Roraima, próximos ao encontrando neste estudo. 
Um fator importante na amostragem que, também, contribui nas incertezas das estimativas de biomassa é a distribuição da biomassa das árvores na floresta. Observandose a Tabela 9, verifica-se que houve uma grande distorção na distribuição de biomassa das árvores, apenas 7 indivíduos com diâmetros acima de $70 \mathrm{~cm}$, representaram cerca de $31 \%$ do total da biomassa áerea de árvores.

Este fato confirma a grande incerteza de estimativas geradas em pequenas parcelas. As estimativas encontradas subdividindo-se a área total em 25 subparcelas de $400 \mathrm{~m}^{2}(20 \times 20 \mathrm{~m})$ produziram médias variando de $42,4 \mathrm{tha}^{-1}$ até $564,71 \mathrm{t} \mathrm{ha}^{-1}$. Brown, et al (1995) afirmaram que pequenas parcelas não são proprícias para estimar as médias para biomassa, já que são insuficientes para captar as árvores de maiores dimensões. Entretanto, quando estas são incluídas nas parcelas geram médias superestimadas.

Tabela 9. Distribuição de freqüência de indivíduos, estoque de biomassa e percentual de biomassa por classe de DAP na área amostrada de 1 ha.

\begin{tabular}{cccc}
\hline DAP & No de indivíduos & Estoque de biomassa & Biomassa \\
\hline $\mathrm{cm}$ & & $\mathrm{t}$ & $\%$ \\
$10-14,9$ & 123 & 9,95 & 4,86 \\
$15-19,9$ & 106 & 16,41 & 8,03 \\
$20-24,9$ & 56 & 17,52 & 8,57 \\
$25-29,9$ & 28 & 12,98 & 6,35 \\
$30-34,9$ & 19 & 14,58 & 7,13 \\
$35-39,9$ & 15 & 13,94 & 6,82 \\
$40-44,9$ & 15 & 19,67 & 9,62 \\
$45-49,9$ & 7 & 12,91 & 6,31 \\
$50-54,9$ & 3 & 7,41 & 3,49 \\
$55-59,9$ & 4 & 8,03 & 3,93 \\
$60-64,9$ & 1 & 3,66 & 1,79 \\
$65-69,9$ & 1 & 3,65 & 1,79 \\
$\geq 70$ & 7 & 60,05 & 31,32 \\
Total & 385 & 204,49 & 100,00 \\
\hline
\end{tabular}




\subsubsection{Biomassa aérea na área derrubada antes da queima}

$\mathrm{Na}$ área amostrada onde a floresta foi derrubada, a biomassa para a classe de madeira $\geq 10 \mathrm{~cm}$ de diâmetro foi estimada, a partir da média dos estoques das quadras (raios) antes de queimar pelo método destrutivo, e complementadas com as médias das quadras deixadas para fase depois da queima pelo método indireto (Line Intersect Sampling - LIS). Os outros componentes foram calculados somente pelo método direto através da colheita destrutiva.

Analisando-se os conteúdos de água nas amostras dos diferentes compartimentos da fitomassa (Tabela 10) nota-se uma grande variação entre eles. Houve uma tendência das peças de material vegetal com maiores diâmetros apresentarem maiores teores de água. Isto também foi verificado por outros autores (Kaufmman et al., 1988, Araújo, 1995).

Tabela 10. Percentual de umidade das amostras vegetais por tipo de material combustivel e classe de diâmetro $(\mathrm{cm})$, na fase antes da queima.

\begin{tabular}{|c|c|c|c|}
\hline Classe/tipo & Umidade & $\mathrm{n}$ & C.V. \\
\hline $\mathrm{cm}$ & $\%$ & & $\%$ \\
\hline \multicolumn{4}{|l|}{ Madeira } \\
\hline$<5 \mathrm{~cm}$ & 36,09 & 18 & 47,51 \\
\hline $5-10 \mathrm{~cm}$ & 59,30 & 18 & 31,73 \\
\hline$\geq 10 \mathrm{~cm}$ & 60,30 & 18 & 16,71 \\
\hline \multicolumn{4}{|l|}{ Cipó } \\
\hline$<5 \mathrm{~cm}$ & 72,39 & 17 & 54,13 \\
\hline $5-10$ & 109,38 & 8 & 42,31 \\
\hline Serapilheira & 27,11 & 18 & 60,62 \\
\hline \multicolumn{4}{|l|}{ Palmeira } \\
\hline$<10 \mathrm{~cm}$ & 253,55 & 2 & - \\
\hline$\geq 10 \mathrm{~cm}$ & 266,58 & 6 & 23,93 \\
\hline Folha de Palmeira & 95,42 & 18 & 56,47 \\
\hline Madeira podre $>10 \mathrm{~cm}$ & 171,33 & 2 & - \\
\hline
\end{tabular}


Deve-se notar que os percentuais de umidade determinados foram reportados após 12 dias da derrubada final, não refletindo o teor de água da floresta antes da queimada que foi exposta a um maior tempo de secagem.O teor de água do material combustível é um dos principais fatores que determinam a eficiência da combustão (Sánchez, 1976; Kaufmman et al., 1988). Desta maneira, é importante a compartimentalização deste material em classes de diâmetro. Assim, espera-se que materiais com maior umidade levem um maior tempo de secagem, o que pode influenciar o resultado da queima.

$O$ estoque total de fitomassa aérea na área derrubada foi de $313,3 \mathrm{tha}^{-1}$, incluindo as árvores deixadas em pé. A classe de madeira $\geq 10 \mathrm{~cm}$ apresentou uma biomassa de $191,3 \mathrm{t} \mathrm{ha}^{-1}$ que correspondeu a $62,4 \%$ do total do material combustível tombado sobre o solo (Tabela 11). A estimativa de biomassa da classe de madeira $\geq 10$ foi apenas $6 \%$ inferior ao valor de 204,5 ton ha ${ }^{-1}$ encontrado para árvores em pé $\geq 10 \mathrm{~cm}$ de DAP, estimado pelo método alométrico no ítem anterior. Nesta, foram incluídos os galhos finos e as folhas das copas das árvores não considerados na classe de madeira $\geq 10$ $\mathrm{cm}$. O emprego de metodologias diferentes para estimar a fitomassa, impossibilita uma análise mais aprofundada dos dados. Entretanto a diferença entre os valores de biomassa não parece ser tão discrepante, apesar da reduzida área de amotragem $\left(720 \mathrm{~m}^{2}\right)$ utilizada na área derrubada. Provavelmente, os efeitos da alta variabilidade espacial da biomassa no local foram compensados pelo desenho amostral. A área de amostragem em forma de "estrela" reduzem o erro de tendenciosidade da disposição das toras sobre o solo, e a forma alongada dos raios são capazes de absorver grande parte desta variabilidade em relação à dimensão dos troncos. É comum durante a derrubada haver um certo direcionamento no tombamento das árvore em um único sentido, que poderia levar a um vício de amostragem. A biomassa das árvores após a derrubada, também, possuem uma distribuição mais agregada, aumentando ainda mais a variabilidade espacial (Fearnside et al., 1993). 
O percentual de contribuição da biomassa de palmeiras $(7,0 \%)$ em relação a biomassa total sobre o solo foi muito próximo aos $6,7 \%$ encontrados por Fearnside et al ${ }^{1}$ em Altamira, Pará. Estes locais coincidem com as regiões de grande ocorrência de babaçus citados por Nelson (1992), na Amazônia.

Tabela 11. Estoque de fitomassa sobre o solo, antes da queima, em cada compartimento e seu percentual em relação a biomassa total.

\begin{tabular}{lccc}
\hline Classe (1) & Estoque de biomassa (2) & $\begin{array}{c}\text { Coeficiente de } \\
\text { Variação }\end{array}$ & $\begin{array}{c}\text { Distribuição } \\
\text { relativa }\end{array}$ \\
\hline $\begin{array}{l}\text { Madeira } \\
<5\end{array}$ & $\mathrm{t}^{-1}$ & $\%$ & $\%$ \\
$5-10$ & $26,5 \pm 3,8$ & 68,1 & 8,6 \\
$\geq 10(3)$ & $21,4 \pm 3,4$ & 75,1 & 7,0 \\
Cipó & $191,3 \pm 24,8$ & 44,9 & 62,4 \\
$\quad<5$ & & & 3,2 \\
$5-10$ & $9,95 \pm 2,7$ & 132,5 & 0,6 \\
Serapilheira & $1,9 \pm 0,5$ & 128,6 & 7,9 \\
Palmeira & $24,1 \pm 2,4$ & 47,7 & 0,1 \\
$\quad<10$ & & & 2,8 \\
$\quad \geq 10$ & $0,32 \pm 0,1$ & 163,6 & 4,1 \\
Folha de Palmeira & $8,6 \pm 2,6$ & 147,1 & 3,2 \\
Madeira podre $>\mathbf{1 0}$ & $12,7 \pm 3,4$ & 129,0 & 100 \\
Total & $9,7 \pm 4,9$ & 244,9 & \\
\hline
\end{tabular}

(1) Sem considerar a biomassa das árvores deixadas em pé na derrubada

(2) Valores expressos pela média \pm erro padrão.

(3) Calculado a partir dos 12 raios de pré e pós-queima das "estrelas", pelo método direto e indireto (de amostragem por linha de interseção). Os outros componentes foram medidos diretamente, como média para 6 raios.

No entanto, em Ariquemes, a biomassa de folhas de babaçu superou em $30 \%$ o valor encontrado para os troncos de palmeiras. Isto evidencia a grande presença de indivíduos jovens de babaçu, que nesta fase são acaules, apresentando uma massa

\footnotetext{
${ }^{1}$ Fearnside, P.M.; Graça, P.M.L. A; Leal Filho, N.; Rodrigues, F.J.A.; Robinson, J.M. Tropical forest burning in Brazilian Amazonia: measurements of biomass, combustion efficiency and charcoal formation at Altamira, Pará (em elaboração).
} 
significativa de folhas. A alta variabilidade espacial dos troncos, também, explica essa diferença. A classe de folhas de babaçu ocorreram em todas as dezoito subquadras $(2 \mathrm{x}$ $10 \mathrm{~m}$ ) amostradas nesta fase, enquanto que os troncos só foram encontrados em seis destas sub-quadras.

Um fator importante no cálculo da biomassa antes da queima é a estimativa de árvores deixadas em pé na área derrubada. A estimativa da biomassa dessas árvores, nem sempre considerada neste tipo de estudo, é importante para confiabilidade dos cálculos da liberação de carbono pela queimada. Em Ariquemes, na área derrubada de, aproximadamente, 3,5 ha foram deixadas oito árvores em pé. Destas, 5 apresentavam copas intactas e as outras três estavam com suas copas danificadas. A biomassa destas árvores foi estimada em $6,8 \mathrm{t} \mathrm{ha}^{-1}$. É comum, em áreas derrubadas, algumas árvores de valor econônico ou protegidas por lei ficarem em pé, propositalmente, como é o caso da castanheira-do-Pará (Kauffman et al. 1995).

A Tabela 12, apresentada a seguir, mostra os resultados deste estudo e de vários outros locais onde foram estimadas as fitomassas no local da derrubada antes da queima. Verificou-se que as estimativas encontradas aqui se enquadram na faixa encontrada por outros autores. No entanto, algumas diferenças entre os compartimentos podem ser observadas, principalmente em relação à massa de troncos e de cipós, demonstrando que as estruturas das florestas na Amazônia podem ser bastante diferentes. Este fato, somado a alta biodiversidade de espécies vegetais, conforme observado por Brown, et al. (1995) pode ser mais um fator que dificulta a estimativa da fitomassa na Amazônia, como um todo.

Observou-se também que em termos de fitomassa total, as florestas abertas foram próximas ou até mesmo superiores do que as florestas densas. Uma possivel explicação para este fato poderiar estar relacionada a distribuição da fitomassa. Como foi demonstrado anteriormente, a maior parte da fitomassa está concentrada apenas em poucas árvores de grandes dimensões. Então, apesar da distribuição das árvores das florestas abertas serem mais esparsas do que as florestas densas, a quantidade de árvores grandes no seu interior compensaria essa menor densidade de árvores. 
Tabela.12. Distribuição aproximada do estoque de biomassa acima do solo da floresta em áreas de derrubada em várias localidades na Amazônia, antes da queima.

\begin{tabular}{|c|c|c|c|c|c|c|c|}
\hline Local & Tipo & $\begin{array}{l}\text { Troncos } \\
\geq 10(1) \\
\end{array}$ & $\begin{array}{l}\text { Galhos } \\
<10(2) \\
\end{array}$ & Cipós & $\begin{array}{l}\text { Serapilheira } \\
\text { (3) }\end{array}$ & $\begin{array}{l}\text { Árvores } \\
\text { em pé }\end{array}$ & Fonte \\
\hline \multicolumn{8}{|c|}{ t ha ${ }^{-1}$} \\
\hline Ariquemes, $\mathrm{RO}$ & Aberta & 209,6 & 48,2 & 11,9 & 36,8 & 6,8 & Este estudo \\
\hline Manaus, AM & Densa & 201,3 & 41,8 & 8,1 & 13,4 & 0,0 & $\begin{array}{l}\text { Fearnside et al. } \\
\text { (1993) }\end{array}$ \\
\hline Manaus, AM & Densa & 272,4 & 55,1 & 10,8 & 36,1 & 0,0 & Fearnside et al. ${ }^{1}$ \\
\hline Altamira, PA & Densa & 146,0 & 44,1 & 32,2 & 34,7 & 5,6 & Fearnside et al. ${ }^{2}$ \\
\hline Tomé-Açu, PA & Densa & $153,0(4)$ & $45,8(5)$ & 4,3 & 11,1 & 0,0 & Araújo (1995) \\
\hline Jacundá, PA & Densa & $222,8(6)$ & $55,0(7)$ & - & 14,6 & 0,0 & $\begin{array}{l}\text { Kauffman et al. } \\
\text { (1995) }\end{array}$ \\
\hline Marabá, PA & Densa & $359,9(6)$ & $53,6(7)$ & - & 21,1 & 0,0 & $\begin{array}{l}\text { Kauffman et al. } \\
\text { (1995) }\end{array}$ \\
\hline Sta.Barbara, RO & Aberta & $202,7(6)$ & $57,8(6)$ & - & 29,8 & 0,0 & $\begin{array}{l}\text { Kauffman et al. } \\
\text { (1995) }\end{array}$ \\
\hline Jamari, RO & Aberta & $255,0(6)$ & $83,1(6)$ & - & 23,8 & 0,0 & $\begin{array}{l}\text { Kauffman et al. } \\
\text { (1995) }\end{array}$ \\
\hline
\end{tabular}

(1) Esta categoria corresponde aos troncos $\geq 10 \mathrm{~cm}$ de diâmetro, incluido também os troncos podres, as palmeiras e os galhos grossos $\geq 10 \mathrm{~cm}$ de diâmetro.

(2) Esta categoria corresponde aos galhos $\leq 10 \mathrm{~cm}$ de diâmetro inclui também os arbustos e as palmeiras menores que $10 \mathrm{~cm}$ de diâmetro.

(3) A categoria de serapilheira inclui também as folhas (inclusive folhas de palmeiras), as flores e os frutos das copas, manta de raízes.

(4) Foi considerado nesta categoria a classe de galhos grossos, subentendido como galhos $\geq 10 \mathrm{~cm}$ de diâmetro.

(5) Foi considerado como galhos $<10 \mathrm{~cm}$ de diâmetro a classe de galhos finos e também a classe subbosque com diâmetro abaixo de $5 \mathrm{~cm}$ adotados pela autora.

(6) Foi incluido nesta categoria peças de material lelhoso acima de $7,6 \mathrm{~cm}$ de diâmetro, adaptado conforme relatado pelos autores

(7) Os cipós foram incluidos juntos com os galhos $\leq 10$, adaptado conforme relatado pelos autores.

1 Fearnside, P.M.; Graça, P.M.L.A.; Rodrigues, F.J.A. Biomass, combustion efficiency and charcoal formation in Amazonia: measurements in a rainforest burn near Manaus, Brazil (em elaboração)

2 Fearnside, P.M.; Graça, P.M.L. A; Leal Filho, N.; Rodrigues, F.J.A.; Robinson, J.M. Tropical forest burning in Brazilian Amazonia: measurements of biomass, combustion efficiency and charcoal formation at Altamira, Pará (em elaboração). 


\subsubsection{Fitomassa acima do solo após a queima}

As médias obtidas para as mesmas quadras, após a queima, pelo método direto e indireto, respectivamente, de $152,7 \mathrm{t} \mathrm{ha}^{-1}$ e $164,8 \mathrm{t} \mathrm{ha}^{-1}$ não diferiram estatisticamente (teste $t, p<0,05)$. Relacionando-se o método indireto por amostragem através de linhas de interseção com o método direto de colheita destrutiva, através de uma análise de correlação, a partir dos estoques de biomassa encontrados para a classe de madeira $\geq 10$ nas subquadras $(2 \times 10 \mathrm{~m})$ após a queima (Figura 11). O coeficiente de correlação (r) encontrado foi de 0,91 , verificando-se uma boa correlação entre as variáveis.

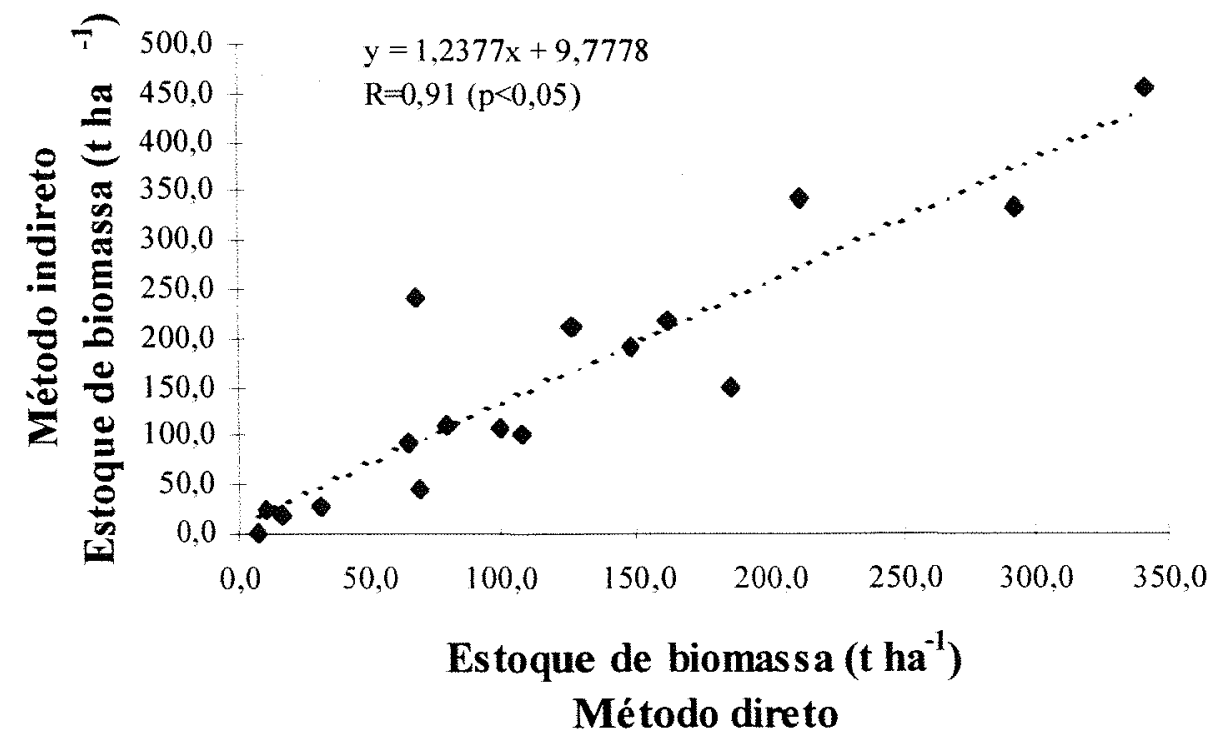

Figura 12 . Relação entre os estoques de biomassa $\left(t h a^{-1}\right)$ para a classe de madeira $\geq 10$ $\mathrm{cm}$ de diâmetro obtidos pelos os métodos indireto e direto, após a queima.

A estimativa da fitomassa após a queima representou cerca de $64,5 \%$ da fitomassa inicial, acima do solo. Observa-se na Tabela 13 que o compartimento representado pela classe madeira $\geq 10 \mathrm{~cm}$ foi o tipo de material combustível que mais contribuiu em relação ao estoque de fitomassa total remanescente sobre o solo, 
representando $79,3 \%$ deste. Os outros compartimentos somados participaram apenas com $20,7 \%$ da fitomassa total remanescente.

Tabela 13. Estoque de fitomassa remanescente sobre o solo, depois da queima, em cada classe de material e seu percentual em relação a biomassa total.

\begin{tabular}{lccc}
\hline Classe de diâmetro(1) & Estoque de biomassa(2) & $\begin{array}{c}\text { Coeficiente de } \\
\text { variação. }\end{array}$ & $\begin{array}{c}\text { Distribuição } \\
\text { relativa }\end{array}$ \\
\hline $\begin{array}{c}\text { Madeira } \\
\quad<5\end{array}$ & $\mathrm{tha}^{-1}$ & $\%$ & $\%$ \\
$\quad 5-10$ & $2,2 \pm 0,4$ & 45,5 & 1,1 \\
$\quad \geq 10$ & $12,4 \pm 1,7$ & 34,7 & 6,3 \\
Cipó & $155,9(3)$ & & 79,3 \\
$\quad<5$ & $1,1 \pm 0,3$ & & \\
$5-10$ & $1,8 \pm 0,6$ & 63,6 & 0,6 \\
Serapilheira & $1,0 \pm 0,5$ & 83,3 & 0,9 \\
Palmeira & & 120,0 & 0,5 \\
$\quad<10$ & $0,9 \pm 0,6$ & & \\
$\quad \geq 10$ & $7,1 \pm 3,1$ & 150,0 & 0,5 \\
Folha de Palmeira & $2,0 \pm 1,9$ & 23,0 & 3,6 \\
Madeira podre & & & 1,0 \\
$\quad>10$ & $0,1 \pm 0,1$ & 400 & 0,05 \\
Carvão & $6,4 \pm 2,7$ & 104,2 & 3,3 \\
Cinzas & $5,7 \pm 1,0$ & 42,5 & 2,9 \\
\hline Total & 196,6 & & 100 \\
\hline
\end{tabular}

(1) Não inclui as árvores deixadas em pé, após a queima

(2) Valores expressos pela média \pm erro padrão. As médias corresponderam aos seis raios de amostragem $(2 \times 30 \mathrm{~m})$ da "estrela" da fase após a queima, pelo método direto.

(3) A fitomassa da classe de madeira $\geq 10$ foi estimada pelo percentual de massa consumida pela queima, considerando apenas o lenho, ou seja excluindo-se os carvões aderidos aos troncos.

\subsubsection{Formação de carvão e cinzas}

Empregou-se os métodos indireto (LIS) e direto (destrutivo) para estimar formação de carvão aderido nas peças de madeira $\geq 10 \mathrm{~cm}$ de diâmetro. O estoque de carvão estimado pelo método indireto, para esta fração foi de $4,48 \mathrm{tha}^{-1}$. Esta estimativa 
foi obtida a partir da densidade aparente média do carvão de 0,43 (devio padrão $=0,11$; $\mathrm{n}=16)$, empregada para converter o volume de carvão em massa $\left(\mathrm{t} \mathrm{ha}{ }^{-1}\right)$.

A estimativa pelo método direto para o estoque carvão aderido (raspado nas quadras) na fração de madeira $\geq 10 \mathrm{~cm}$ de diâmetro foi de $3,11 \mathrm{t} \mathrm{ha}^{-1}$, que correspondeu a $48,5 \%$ do estoque total de carvão medido nas quadras após a queima. As médias estimadas para ambos os métodos não diferiram estatisticamente (teste $t, p<0,05$ ). Relacionando-se o método direto com o indireto, a partir dos estoques (massa) encontrados nas sub-quadras $(2 \times 10 \mathrm{~m}$ ), através de uma análise de correlação (Figura 13) encontrou-se um coeficiente de correlação entre as variáveis de 0,91. Assim, verificou-se uma estreita relação entre estas duas variáveis. Neste estudo, considerou-se para os cálculos relacionados aos estoques de carbono, a formação de carvão do método direto.

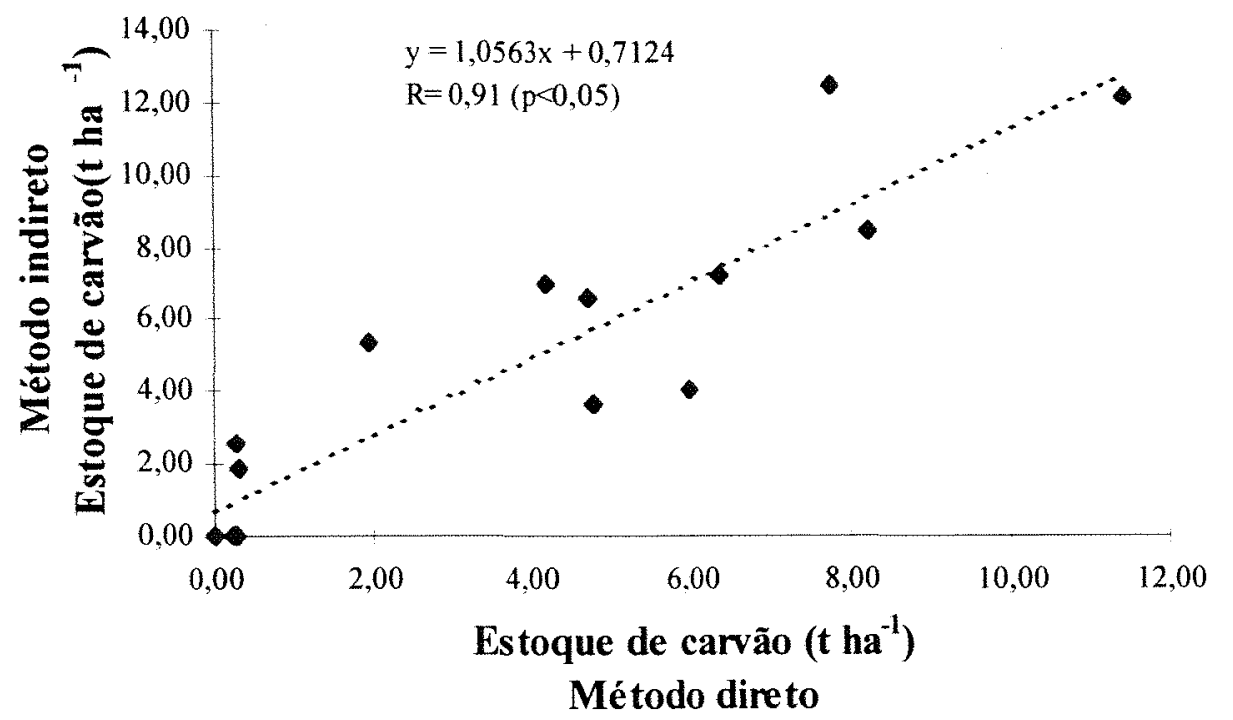

Figura 13. Relação entre os estoques de carvão para a classe de madeira $\geq 10 \mathrm{~cm}$ de diâmetro obtidos pelos os métodos indireto e direto, após a queima. 
A quantificação de carvão vegetal em queimadas na Amazônia tem sido raramente estimada. Apenas dois estudos (Fearnside, 1993; Fearnside et al. ${ }^{1}$ ) relacionados a queimadas na Amazônia mencionaram explicitamente a quantidade de carvão. Estes foram estimados em 4,7 $\mathrm{t} \mathrm{ha}^{-1}$, numa queimada próxima à Manaus (Fearnside et al., 1993), e 2,2 t ha ${ }^{-1}$, em Altamira, Pará, (Fearnside et al. ${ }^{1}$ ). O valor encontrado em Ariquemes foi superior a estes dois.

Tabela 14. Resultados encontrados para quantidade de cinzas em queimadas na Amazônia

\begin{tabular}{|c|c|c|c|}
\hline $\begin{array}{l}\text { Tipo de vegetação e } \\
\text { localidade }\end{array}$ & $\begin{array}{l}\text { Estoque de } \\
\text { cinzas }\end{array}$ & Método empregado & Referência \\
\hline & $\mathrm{tha}^{-1}$ & & \\
\hline $\begin{array}{l}\text { Floresta aberta, } \\
\text { Ariquemes, RO }\end{array}$ & 5,4 & Coleta manual & Presente estudo \\
\hline $\begin{array}{l}\text { Floresta densa, Capitão } \\
\text { Poço, PA }\end{array}$ & 17,2 & Coleta manual & Dantas \& Matos, 1981 \\
\hline $\begin{array}{l}\text { Floresta densa, Manaus, } \\
\text { AM. }\end{array}$ & 9,2 & Coleta manual & Smyth \& Bastos, 1984 \\
\hline $\begin{array}{l}\text { Floresta densa, Jacundá, } \\
\text { PA. }\end{array}$ & 8,8 & $\begin{array}{l}\text { Placas de Petri (densidade) } \\
\text { e medidas de profundidade }\end{array}$ & Kauffman et al., 1995 \\
\hline $\begin{array}{l}\text { Floresta densa, Marabá, } \\
\text { PA }\end{array}$ & 10,9 & $\begin{array}{l}\text { Placas de Petri (densidade) } \\
\text { e medidas de profundidade }\end{array}$ & Kauffman et al., 1995 \\
\hline $\begin{array}{l}\text { Floresta aberta, Santa } \\
\text { Bárbara, RO }\end{array}$ & 9,4 & $\begin{array}{l}\text { Coleta com aspirador de pó } \\
\text { elétrico portátil }\end{array}$ & Kauffman et al., 1995 \\
\hline $\begin{array}{l}\text { Floresta aberta, Jamari, } \\
\text { RO. }\end{array}$ & 7,2 & $\begin{array}{l}\text { Coleta com aspirador de pó } \\
\text { elétrico portátil }\end{array}$ & Kauffman et al., 1995 \\
\hline
\end{tabular}

A quantidade encontrada de cinzas foi de $5,7 \mathrm{t} \mathrm{ha}^{\mathrm{l}}$ (excluindo-se os carvões possiveis de serem separados manualmente) inferior a maioria dos valores encontrados na literatura para florestas primárias na Amazônia (Tabela 14). Este valor é menor que aqueles (9,4 $\mathrm{t}$ $h^{-1}$ e $7,2 t^{-1} a^{-1}$ ) encontrados por Kauffman et al. (1995) em Rondônia. Isto pode ter ocorrido em decorrência da chuva $(8 \mathrm{~mm})$ que caiu no dia anterior prejudicando a coleta.

${ }^{1}$ Fearnside, P.M.; Graça, P.M.L. A; Leal Filho, N.; Rodrigues, F.J.A.; Robinson, J.M. Tropical forest burning in Brazilian Amazonia: measurements of biomass, combustion efficiency and charcoal formation at Altamira, Pará (em elaboração). 
As diferentes metodologias empregadas para sua quantificação e a falta de uma definição comum (alguns autores incluem também os fragmentos de carvão) para as cinzas dificultam as comparações entre os resultados.

\subsubsection{Eficiência de combustão e liberação de carbono durante a queimada}

Conforme pode ser observado na Figura 14, os valores percentuais de queima de biomassa (somente o material lenhoso, não incluindo o carvão) mostram que a fração de madeira $\geq 10 \mathrm{~cm}$ foi a que mais resistiu à ação do fogo, consumindo apenas $18,5 \% \mathrm{da}$ sua massa original. Entretanto, as frações de galhos finos, cipós; serapilheira e folhas de palmeiras tiveram suas massas drasticamente reduzidas pela queima. Por exemplo, a classe de madeira $<5 \mathrm{~cm}$ de diâmetro teve a sua massa reduzida em $91,7 \%$.

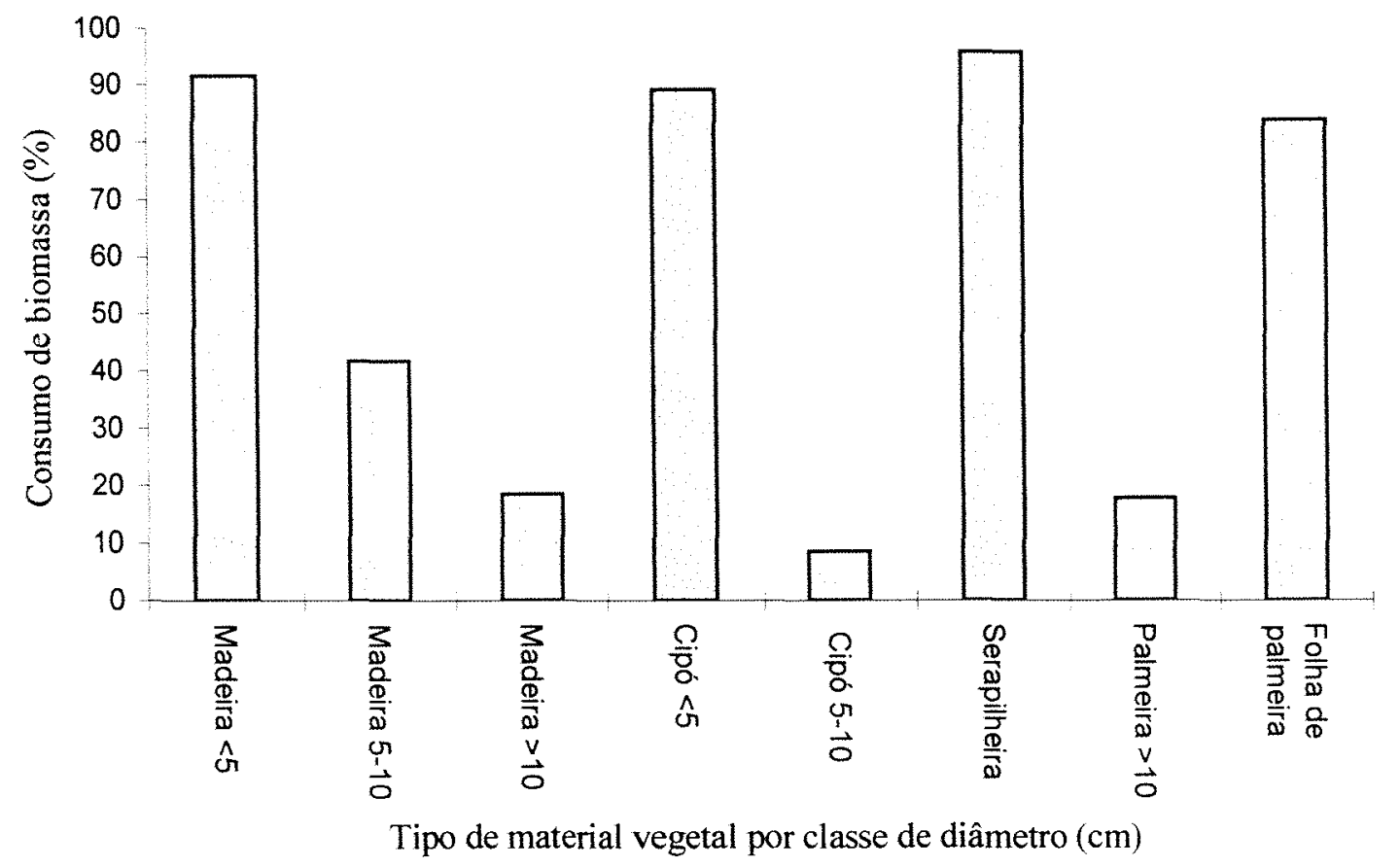

Figura 14. Percentual de consumo de fitomassa acima do solo pela queima por tipo de material e classe de diâmetro. 
A classe de palmeira $<10 \mathrm{~cm}$ de diâmetro teve um leve aumento no seu estoque de biomassa, sendo considerado seu percentual de consumo de biomassa igual a zero. A distribuição desta classe é muito irregular, encontrada apenas em duas subquadras $(2 \times 10$ $\mathrm{m}$ ). Isso indica que deve ser necessário um número muito maior de repetições ou parcelas maiores para amostrar adequadamente essa classe que foi altamente variável.

Em geral, a mesma tendência em relação ao consumo destes componentes foi encontrada em outros estudos sobre a queima de florestas em áreas sujeitas à prática de corte e queima na Amazônia (Fearnside et al., 1993; Kauffman et al., 1995; Araújo, 1995). Porém o percentual de queima da fitomassa sobre o solo poderá variar bastante conforme a quantidade de material combustível empilhado e a qualidade deste material presente na área derrubada, assim como as condições climáticas no momento da queima (Jordan, 1985; Kauffman, et al., 1988).

A distribuição aproximada de carbono na fitomassa acima do solo e a quantidade de carbono liberado pela queima estão apresentadas na Tabela 15. A eficiência de combustão foi de $34,6 \%$, ou seja, foram liberados $49,4 \mathrm{t} \mathrm{ha}^{-1}$ de carbono durante a queimada para a atmosfera. Após a queima permaneceram, no local, $65,4 \%$ do carbono contido no estoque original da biomassa.

A eficiência de combustão em queimadas na Amazônia varia entre $22 \%$ e $56 \%$ (Fearnside et al.1993; Kauffman et al., 1995, Araújo, 1995). Os maiores valores foram os de Kauffman et al. (1995), que encontraram em média um coeficiente de combustão de $50 \%$, em relação ao estoque total de carbono antes da queima, no Pará e Rondônia. Kauffman et al. (1995) argumentaram que este valor é maior do que aqueles (cerca de 28 \%) usados em estudos de sobre emissão líquida de carbono para a atmosfera pela queima de florestas tropicais, adotados por Fearnside (1992a) e Crutzen \& Andreae (1990). Estes autores, também afirmaram que estes valores menores para eficiência de combustão, provavelmente não seriam representativos para áreas sujeitas a desmatamentos e queimadas, como no Pará e em Rondônia. Assim, a entrada de C na atmosfera via processos de decomposição poderiam estar superestimados. 
Tabela 15. Distribuição do carbono da biomassa acima do solo e carbono liberado na Fazenda Nova Vida, RO.

\begin{tabular}{|c|c|c|c|c|c|c|c|}
\hline \multirow{2}{*}{$\begin{array}{l}\text { Fração de biomassa } \\
\text { por classe de } \\
\text { diâmetro }\end{array}$} & \multicolumn{3}{|c|}{ Fase antes da queima } & \multicolumn{3}{|c|}{ Fase depois da queima } & \multirow{2}{*}{$\begin{array}{l}\text { Percentual do estoque } \\
\text { total de carbono antes } \\
\text { da queima deixado na } \\
\text { fração }\end{array}$} \\
\hline & Fitomassa & Carbono & Carbono & Fitomassa & Carbono & Carbono & \\
\hline $\mathrm{cm}$ & $\mathrm{tha}^{-1}$ & $\%$ & tha & $\mathrm{tha}^{-1}$ & $\%$ & $\mathrm{tha}^{-1}$ & \\
\hline Madeira $<5$ & 26,50 & $44,4(18 ; 2,1)$ & 11,8 & 2,2 & $44,5(16 ; 1,8)$ & 1,0 & 0,7 \\
\hline Madeira 5-10 & 21,40 & $44,6(18 ; 1,6)$ & 9,5 & 12,5 & $45,7(16 ; 2,6)$ & 5,7 & 4,0 \\
\hline Madeira $\geq 10$ & 191,3 & $46,4(18 ; 3,1)$ & 88,7 & 155,9 & $46,8(18 ; 3,0)$ & 73,0 & 51,0 \\
\hline Cipó $<5$ & 10,0 & $44,9(17 ; 1,8)$ & 4,5 & 1,1 & $44,7(11 ; 3,7)$ & 0,5 & 0,3 \\
\hline Cipó 5-10 & 1,9 & $42,9(8 ; 1,4)$ & 0,8 & 1,8 & $44,0(9 ; 1,6)$ & 0,8 & 0,5 \\
\hline Cipó $\geq 10$ & ausente & ausente & ausente & ausente & ausente & ausente & 0,0 \\
\hline Palmeira $<10$ & 0,3 & $41,5(2 ;-)$ & 0,1 & 0,9 & $46,4(2 ;-)$ & 0,4 & 0,3 \\
\hline Palmeira $\geq 10$ & 8,6 & $46,3(6 ; 1,9)$ & 4,0 & 7,1 & $45,5(7 ; 1,1)$ & 3,2 & 2,3 \\
\hline Folhas de palmeira & 12,7 & $44,1(18 ; 3,5)$ & 5,6 & 2,0 & $44,4(5 ; 1,2)$ & 0,9 & 0,6 \\
\hline Serapilheira e folhas & 24,1 & $42,8(18 ; 3,5)$ & 10,3 & 1,0 & $39,5(8 ; 6,0)$ & 0,4 & 0,3 \\
\hline Madeira podre $\geq 10$ & 9,7 & $46,4(2 ;-)$ & 4,5 & 0,2 & $35,4(1 ;-)$ & 0,1 & 0,0 \\
\hline Carvão & ausente & ausente & ausente & 6,4 & $64,6(172 ; 6,3)$ & 4,1 & 2,9 \\
\hline Cinzas & ausente & ausente & ausente & 5,7 & $6,6(6 ; 1,7)$ & 0,4 & 0,3 \\
\hline Árvores em pé & 6,8 & $46,4(-;-)$ & 3,2 & 6,8 & $46,4(-;-)$ & 3,2 & 2,0 \\
\hline Total & 313,3 & & 143,0 & 203,5 & & 93,6 & 65,4 \\
\hline Carbono Liberado & & & & & & 49,4 & 34,6 \\
\hline
\end{tabular}

-O valor da fração de biomassa de madeira $\geq 10$ na fase depois da queima foi estimado a partir do coeficiente de queima encontrado pelo método indireto (LIS).

-Os valores entre parênteses correspondem, respectivamente, ao número de amostras e ao desvio padrão.

-O valor percentual de carbono para árvores em pé foi considerado sendo o mesmo da fração madeira $\geq 10$, antes da queima 
Entretanto, o valor encontrado por este estudo também foi menor (30\% a menos) do que aquele encontrado por Kauffman et al. (1995). A distribuição inicial dos componentes da fitomassa antes da queima pode explicar, em parte, essa diferença (Figura 15).
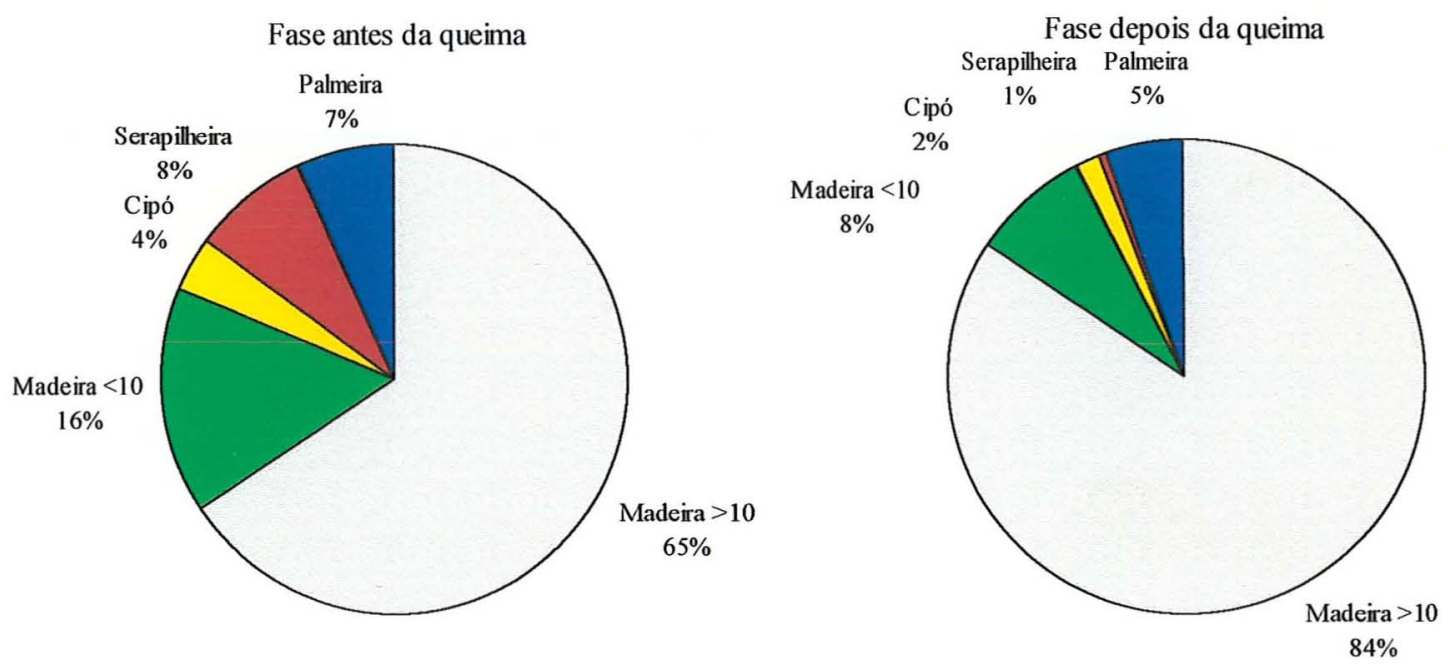

Figura 15. Comparação entre a distribuição aproximada dos compartimentos da fitomassa tombada sobre o solo antes e depois da queima, por tipo material combustível e classe de diâmetro $(\mathrm{cm})$.

A fração de madeira $\geq 10 \mathrm{~cm}$ (incluindo a madeira podre) participou com $66 \%$ da biomassa total derrubada sobre o solo, antes da queima. Após a queimada este percentual aumentou para $84 \%$ em relação ao total de biomassa remanescente (excluindo-se os carvões e cinzas). Isso demonstra que as frações de menores dimensões podem ter grande influência no resultado final do coeficiente de combustão. Fearnside et al. ${ }^{1}$ relataram que a distruibuição inicial de biomassa entre as frações, explicam, em grande parte, as diferenças existentes entre os coeficientes de combustão em queimadas, indicando uma

\footnotetext{
${ }^{1}$ Fearnside, P.M.; Graça, P.M.L. A; Leal Filho, N.; Rodrigues, F.J.A.; Robinson, J.M. Tropical forest burning in Brazilian Amazonia: measurements of biomass, combustion efficiency and charcoal formation at Altamira, Pará (em elaboração).
} 
das características de variabilidade que pode afetar a eficiência de combustão. Por exemplo, este estudo que teve uma eficiência de combustão de $34,6 \%$, a fração de madeira $\geq 10 \mathrm{~cm}$ participou com $61 \%$ do estoque total da fitomassa aérea antes da queima, enquanto que em Manaus (Fearnside et al., 1993) os troncos acima de $10 \mathrm{~cm}$ participaram com $76 \%$ da biomassa total acima do solo, obtendo uma eficiência de combustão menor, de $27,5 \%$. No entanto, o percentual de consumo de biomassa para a fração madeira $\geq 10$ em Manaus $(20,9 \%$ ) foi levemente superior aos $18,5 \%$ encontrados em Ariquemes

Outro argumento que pode explicar a alta variabilidade na eficiência das queimadas, na Amazônia, pode estar relacionada às variações climáticas anuais, durante o curto período no qual esta prática é empregada. Fearnside (1989) avaliando a qualidade da queimada em áreas de agricultura, na rodovia Transamazônica, observou que a qualidade da queima variou de ano para ano, entre os fazendeiros desta região. Assim, demonstrou que a variabilidade da queima é um fator chave que afeta a produção agrícola e, consequentemente, a capacidade de suporte de populações humanas, em áreas de colonização recente na Amazônia.

Portanto, um número maior de estudos relacionados a eficiência de combustão seria necessário para que se tenha uma média mais representativa nas áreas de ocorrência de queimadas na Amazônia.

A Figura 16 mostra a distribuição dos percentuais de carbono após a queima da floresta. Verificou-se que cerca de $62 \%$ do carbono permaneceu no sistema na forma de fitomassa remanescente da queima. Este estoque de carbono ainda poderá ser introduzido na atmosfera pelas próximas décadas, seja pela decomposição lenta e gradual da madeira, principalmente por microrganismos, cupins e intempéries, ou através de sucessivas requeimas de pastagens ou da vegetação secundária para fins agrícolas (Fearnside 1992, Houghton, 1994). Os outros 3\% permaneceram na forma de carvões e cinzas.

O carvão é considerado uma fonte de carbono de difícil decomposição. É comum encontrar carvões de origem vegetal incorporados no solo em regiões da Amazônia datados em até 6000 anos (Sanford, et.al., 1985; Gomes, 1995). Seiler \& Crutzen (1980) 
consideraram as formações de carvão como importante dreno (sumidouro) de carbono em queimadas de florestas tropicais, contribuindo com cerca de 20 a $30 \%$ do estoque total de carbono da fitomassa remanescente, ou 15 a $23 \%$ do carbono da fitomassa total acima do solo antes da queima. Em trabalho mais recente, Crutzen \& Andreae (1990) usaram um valor de $5 \%$ para formação de carvão em relação a fitomassa total sobre o solo antes da queima. Este valor ainda é mais alto do que os $3 \%$ encontrados neste estudo, em relação ao estoque total de carbono da biomassa, antes da queima. Esta estimativa foi muito próxima dos 2,7\% encontrados por Fearnside et al. (1993), confirmando até agora que a formação de carvão em queimadas na Amazônia tem uma contribuição bastante reduzida como fonte de carbono de longa duração.

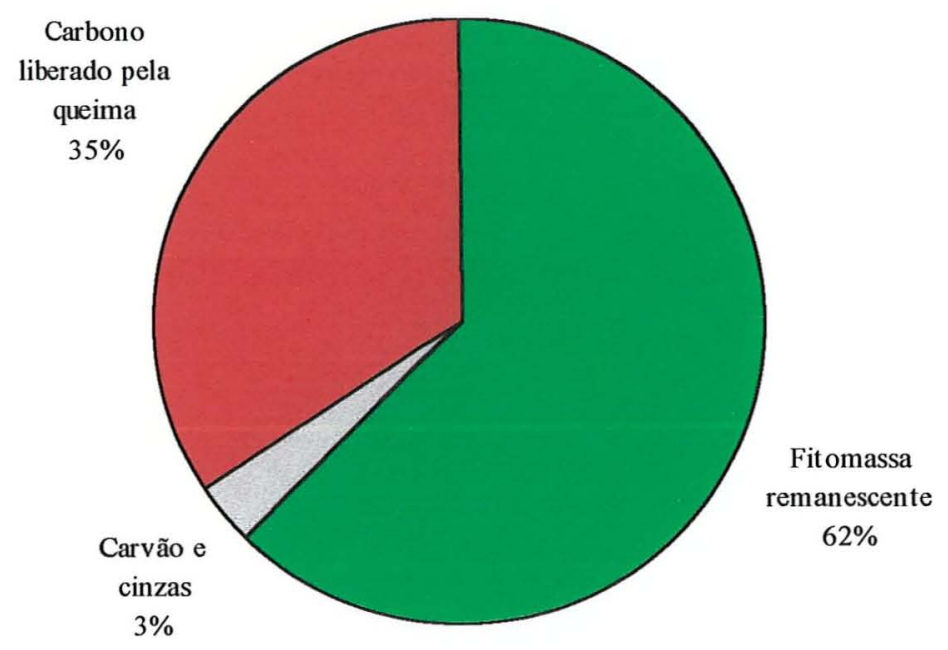

Figura 16. Distribuição relativa do carbono após a queimada em Ariquemes.

A quantidade de carbono contida nas cinzas foi pequena $\left(0,4 \mathrm{t} \mathrm{ha}^{-1}\right.$ de carbono), contribuindo em $0,3 \%$ de carbono em relação ao estoque total antes da queima. $\mathrm{O}$ teor de carbono nas cinzas foi de $6,6 \%$ (desvio padrão $=1,7, n=6$ ).

O estoque de carbono encontrado antes da queima de $142,6 \mathrm{t} \mathrm{ha}^{-1}$ foi reduzido a 93,6 $\mathrm{t} \mathrm{ha}^{-1}$ pela ação do fogo. Isto significa que foram emitidos no momento da queimada, presumivelmente em sua maior parte na forma de $\mathrm{CO}_{2}$, uma quantidade de $49 \mathrm{t}$ 
$\mathrm{ha}^{-1}$ de carbono para a atmosfera. Considerando-se a área de 3,5 ha de floresta derrubada, a quantidade liberada de carbono foi de 171,5 toneladas. É provável que uma pequena quantidade de carbono tenha saído do sistema na forma grafítica (fuligem), porém assume-se que esta quantidade seja insignificante. Outra parte que também não foi quantificada, considerada desprezível, foi aquela presente nos carvões finos sobre o solo, que escaparam da coleta manual, se bem que uma parte deste carvão pulverizado foi incluida nas amostras de cinzas.

A Figura 17 resume as alterações ocorridas no carbono contido na fitomassa aérea antes e imediatamente após a queima da floresta e o seu destino.

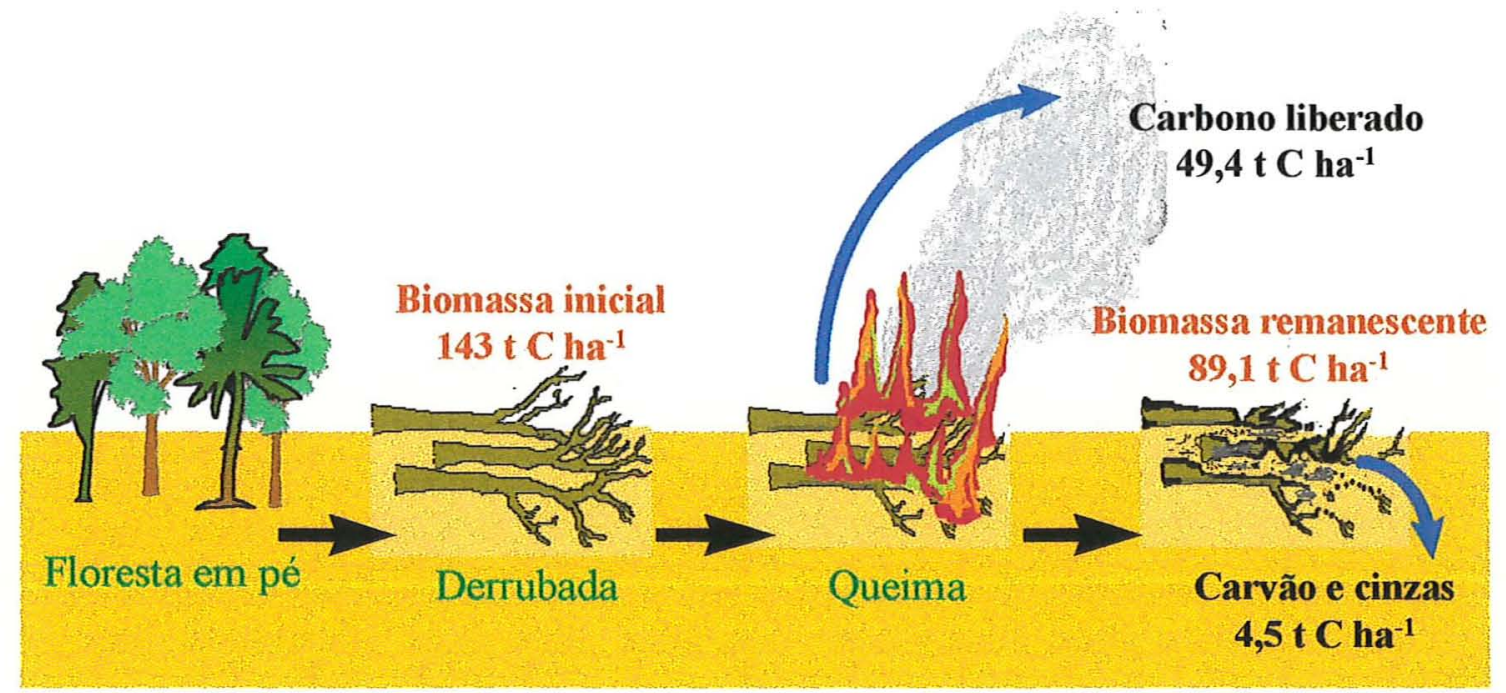

Eficiência de combustão $34,6 \%$

Figura 17. Destino do carbono da fitomassa aérea, antes e imediatamente após a queima.

\subsection{Mudanças no estoque de carbono no solo após a queima da vegetação.}

As médias dos teores de carbono total (\%) do sistema alterado (local da queimada) e do sistema natural (floresta testemunha) foram analisadas estatisticamente através da análise de variância (ANOVA), para a interação dos efeitos de locais de coleta, data de coleta e profundidade. As médias dos dois sistemas não apresentaram diferenças estatisticamente significativas (teste F, em nível de 0,05). Observando-se a Figura 18, 
verifica-se que houve um descréscimo no teor de carbono total em função da profundidade, para os dois sistemas. Isto pode estar ligado ao maior aporte de resíduos vegetais do sistema radicular e da parte aérea da floresta, bem como à maior atividade biológica nas camadas superfíciais.
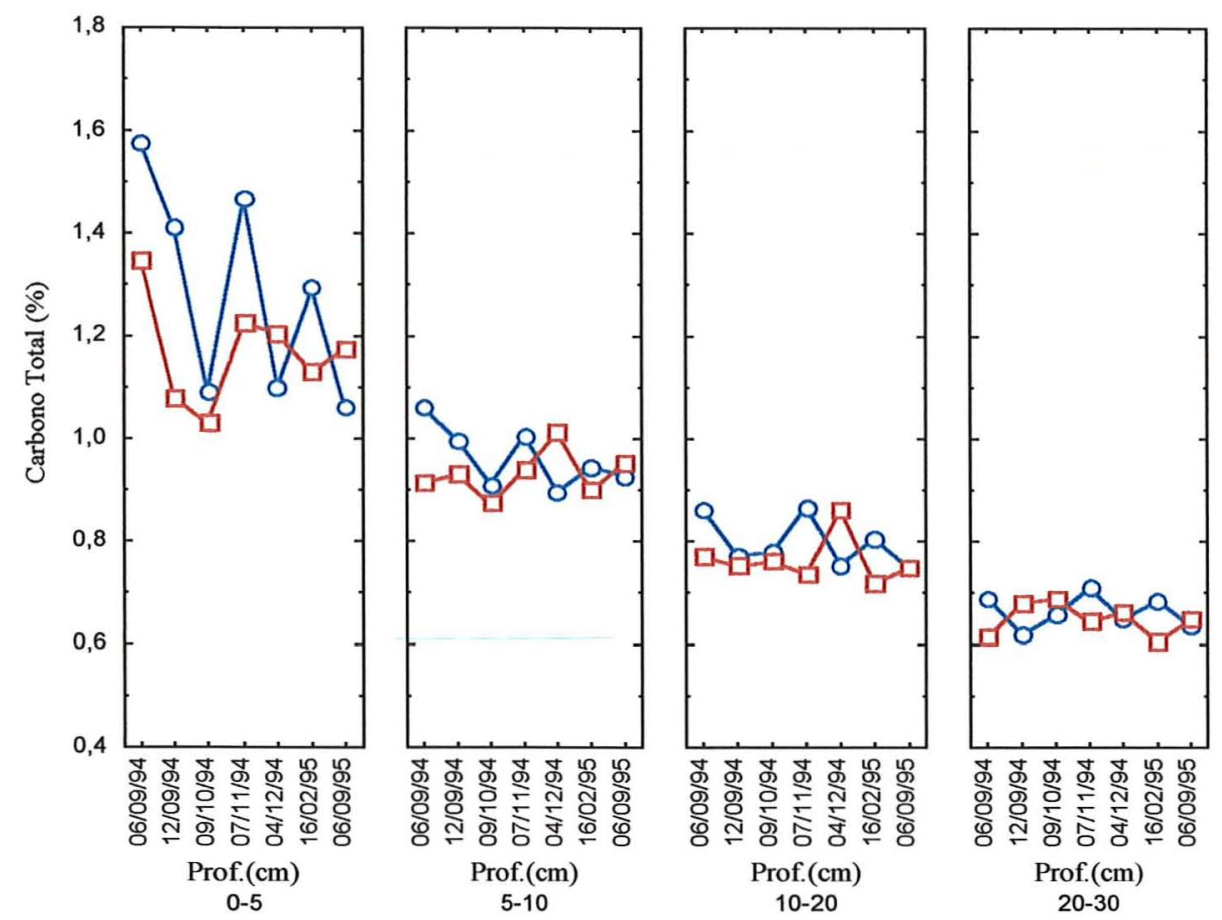

-O- SISTEMA Alterado

$-\square-$ SISTEMA Natural

Figura 18. Valores médios de teores de carbono nos sistemas estudados para cada profundidade amostras, nas datas de coleta. As interações entre os três efeitos foram analisados através da Análise de Variância (ANOVA).

As maiores oscilações no teor de carbono total (\%) ocorreram na camada de 0-5 $\mathrm{cm}$. Nesta camada, em ambos os sistemas, houve uma tendência de redução nos teores de carbono ao final do período de um ano, em relação aos níveis iniciais após a derrubada. Porém, os valores não foram significativos, em grande parte devido a variância dos dados. Uma tendência inversa foi observada, nesta mesma camada para o sistema natural, nas duas últimas datas de coletas, no intervalo de duzentos e treze dias. Neste período, a 
floresta mostrou uma ligeira tendência a retornar aos níveis iniciais, enquanto que o sistema alterado manteve uma tendência à redução do teor de carbono.

Os estoques de carbono nas camadas do solo nos dois sistemas estão apresentados na Tabela 16. As médias dos estoques entre os dois sistemas, conforme foi observado para os teores de carbono não apresentaram diferenças estatisticamente significativas (teste de $\mathrm{F}$, em nível de 0,05 ). No periodo observado de um ano, o estoque total médio de carbono, no sistema alterado, variou entre $32,1 \mathrm{t} \mathrm{ha}^{-1}$ e $27,0 \mathrm{t} \mathrm{ha}^{-1}$ para a camada de $0-30 \mathrm{~cm}$ do solo, para cada data de coleta. No sistema natural o estoque total médio variou entre $28,3 \mathrm{tha}^{-1}$ e $26,8 \mathrm{t} \mathrm{ha}{ }^{-1}$.

Tabela 16. Estoque de carbono nos solos dos sistemas alterado e natural, nas camadas de 0-10, 10-20, 20-30 cm, no periodo de um ano de amostragem.

\begin{tabular}{lcccc}
\hline & \multicolumn{3}{c}{ Carbono } & \\
\cline { 2 - 3 } Data de coleta & $0-10$ & $10-20$ & $20-30$ & Total \\
\cline { 2 - 3 } & \multicolumn{3}{c}{ Sistema Alterado } \\
06/09/94 & 14,0 & 10,0 & 8,1 & 32,1 \\
$12 / 09 / 94$ & 13,2 & 9,1 & 7,4 & 29,7 \\
$09 / 10 / 94$ & 11,0 & 9,2 & 7,8 & 27,0 \\
$07 / 11 / 94$ & 13,6 & 9,9 & 8,5 & 32,0 \\
$04 / 12 / 95$ & 11,0 & 8,9 & 7,8 & 26,7 \\
$16 / 02 / 95$ & 12,3 & 9,5 & 8,2 & 30,0 \\
$06 / 09 / 95$ & 11,0 & 8,8 & 7,6 & 27,4 \\
& & Sistema Natural & & \\
$06 / 09 / 94$ & 12,0 & 8,9 & 7,2 & 28,1 \\
$12 / 09 / 94$ & 11,1 & 8,9 & 8,1 & 28,1 \\
$09 / 10 / 94$ & 10,4 & 9,0 & 8,2 & 27,6 \\
$07 / 11 / 94$ & 11,9 & 8,7 & 7,7 & 28,3 \\
$04 / 12 / 95$ & 12,6 & 8,7 & 7,5 & 27,8 \\
$16 / 02 / 95$ & 11,0 & 8,5 & 7,3 & 26,8 \\
$06 / 09 / 95$ & 11,3 & 8,8 & 7,4 & 27,5 \\
\hline
\end{tabular}


As temperaturas do solo durante a queimada não são altas o suficiente para afetar consideravelmente o teor de matéria orgânica do solo (Sánchez, 1976). Ewel et al. (1981) estudando o efeito da queima numa floresta secundária com cerca de 9 anos, observaram que a temperatura foi reduzida drasticamente de $200{ }^{\circ} \mathrm{C}$, em média, na superficie do solo para uma média de $100^{\circ} \mathrm{C}$ a $1 \mathrm{~cm}$ de profundidade, chegando a menos de $38^{\circ} \mathrm{C}$, em média, na camada inferior a $3 \mathrm{~cm}$ de profundidade. A mesma tendência foi observada por Zinke et al., (1970) para queimadas em sistemas de cultivo intinerante na Tailândia. Observa-se, também, uma alta variabilidade no efeito do fogo no aumento da temperatura do solo, variando de ponto para ponto no local da queimada, dependendo da quantidade, da qualidade e da umidade do material combustível (Ewel, et al., 1980). No caso de queima na forma de coivara (empilhamento de resíduos vegetais), onde a carga combustível está concentrada, a temperatura pode alcançar até $150{ }^{\circ} \mathrm{C}$ nos primeiros 5 $\mathrm{cm}$ de profundidade do solo (Zinke et al., 1970).

Presume-se neste experimento que, caso a temperatura tenha alcançado níveis capazes de promover a oxidação da matéria orgânica do solo, ela ocorreu pontualmente no local da queima, onde havia uma maior concentração de material combustível, e não foi captada pela amostragem.

O acréscimo de resíduos vegetais de fácil decomposição, tais como, folhas desprendidas das copas e galhos finos (pouco lignificados) após a derrubada, a deposição de partículas de carvão encontradas nas cinzas e materiais parcialmente carbonizados após queima, contribuiram para aumentar o teor de carbono no sistema alterado quando comparado com o sistema natural. Outros estudos efeitos por Nye \& Greenland (1964), em Gana, Seubert et. al. (1977) e Sánchez et al. (1983), no Peru, também, observaram um ligeiro aumento no teor de carbono orgânico do solo, imediatamente após a queima.

O declínio do teor de carbono pouco acentuado, não estatisticamente significante, em relação ao sistema natural, ao longo do período de observação, indica que as mudanças no conteúdo de carbono do solo não ocorrem instaneamente, conforme foi relatado por Detwiler (1986). 
Neste estudo, a comparação do sistema alterado com a floresta foi fundamental. Pois a aparente redução do teor de carbono no sistema alterado, quando analisado isoladamente, após a queima mostrou estar provavelmente mais relacionada aos fatores climáticos do que propriamente à ação do fogo. Assim estudos que quantificam a liberação de carbono em solos sob queimadas, coletando-se as amostras de solo somente no local da queimada, podem estar superestimando o efeito do fogo.

\subsection{Contribuição da queima da biomassa florestal para a emissão de carbono para a atmosfera}

A grande quantidade carbono estocado na biomassa florestal pode ter uma contribuição significante para o aumento da concentração de carbono na atmosfera, caso as queimadas na Amazônia continuem indiscriminadamente. Uma primeira aproximação para estimar a quantidade de carbono emitida no instante da queimada até o ano de 1994, será feita a seguir, com finalidade de ilustrar melhor esta questão.

Desta maneira, considerou-se que todos os desmatamentos (apenas florestas) na Amazônia foram acompanhados pela queima da biomassa florestal, o que é bastante provável. Assume-se, também, que houve uma redução de $6,5 \%$ do total da biomassa acima do solo pela exploração madeireira, antes da queima. Este percentual foi calculado em relação a redução média de biomassa aérea na hora da derrubada, na Amazônia em 1990, estimado por Fearnside (1994).

De acordo com o INPE (1996), a área na Amazônia Legal desflorestada até 1994 foi de $470 \times 10^{3} \mathrm{~km}^{2}$. Se considerarmos a biomassa aérea média após a exploração madeireira, estimada aqui, em $308,7 \mathrm{t} \mathrm{ha}^{-1}$, incluindo a biomassa morta sobre o solo de $24,4 \mathrm{t} \mathrm{ha}^{-1}$ (ajustado pelo fator de 1,09 adotado por Fearnside, 1994) e o conteúdo de $50 \%$ de carbono para a biomassa, encontrariamos uma carga combustível de 7,3 Pg de carbono disponível para a queima. Aplicando-se um coeficiente de combustão médio de $40 \%$, a partir de valores encontrados na fazenda Nova Vida, RO, e em outras localidades 
na Amazônia (Araújo, 1995; Fearnside, 1993; Fearnside et al. ' Kauffman et al., 1995), esta carga combustível inicial de 7,3 $\mathrm{PgC}$ sofreria uma redução em seu estoque de aproximadamente 2,9 PgC. Esta seria apenas a quantidade de carbono prontamente liberada pela queima na forma de $\mathrm{CO}_{2}$. O restante $(4,4 \mathrm{PgC})$ seria liberado posteriormente pelo proceso de decomposição e requeimas. A quantidade prontamente liberada, do total desmatado até o ano de 1994 , representa cerca de $0,4 \%$ do estoque de carbono de $750 \mathrm{Pg}$ existente na atmosfera (IPCC, 1994). Não é considerado aqui, a remoção do carbono pela vegetação secundária presente após o desmatamento, já que está sendo considerado apenas o potencial de emissão. Mesmo assim, a remoção pela vegetação secundária parece ser insignificante. Fearnside \& Malheiros (1996) estimaram para o ano de 1990 uma remoção líquida de carbono pela vegetação secundária de apenas 2,0 $\mathrm{Tg}\left(1 \mathrm{tg}=10^{12} \mathrm{~g}\right)$ de carbono (diferença anual entre o carbono retirado pela vegetação secundária e o emitido pela sua queima) representando apenas $0,5 \%$ da emissões totais de carbono para este ano, pelo desmatamento na Amazônia Legal.

Agora, analisando em termos de emissão anual, admitindo-se uma taxa de desflorestamento de $14,9 \times 10^{3} \mathrm{~km}^{2}$ (INPE, 1996), para o período de 1992 a 1994 , encontraremos uma emissão bruta de carbono causada pela queima inicial da biomassa de $92,0 \mathrm{TgC}$ ano $^{-1}$. Esta estimativa é mais alta do que os $62,2 \mathrm{TgC}_{\text {ano }}{ }^{-1}$ utilizado por Fearnside \& Malheiros (1996), como emissão bruta da queima inicial, para para calcular o balanço anual da emissões de carbono no ano de 1991. Os motivos para esta diferença possivelmente estão nos diferentes valores usados na estimativa da biomassa inicial da floresta, no coeficiente de combustão, e na taxa anual de desmatamento.

Esse fluxo anual de carbono corresponderia, aproximadamente, a 5,7 \% das emissões líquidas, causadas pelas mundanças no uso da terra nos trópicos estimado em $1,6 \mathrm{Pg}$ ano $^{-1}$ para o período de 1980 a 1989 pelo IPCC (1994).

\footnotetext{
${ }^{1}$ Fearnside, P.M.; Graça, P.M.L. A; Leal Filho, N.; Rodrigues, F.J.A.; Robinson, J.M. Tropical forest burning in Brazilian Amazonia: measurements of biomass, combustion efficiency and charcoal formation at Altamira, Pará (em elaboração).
} 
Assim, pode-se perceber que apenas a queima inicial da biomassa na Amazônia, sem considerar a maior parte que será liberada posteriormente pelos processos de decomposição e requeima, tem uma importância significativa nas emissões globais de carbono. 


\section{CONCLUSÕES}

As estimativas encontradas para a fitomassa na Amazônia indicam um grande potencial das florestas em estocarem carbono, confirmando seu importante papel em afetar os fluxos de carbono entre o sistema terrestre e atmosférico.

A queima da floresta, em Rondônia, teve pouco efeito na redução da biomassa da classe de madeira com diâmetro $\geq 10 \mathrm{~cm}$, tais como troncos e galhos grossos de árvores, que representam a maior parte da biomassa aérea.

Os dados de formação de carvão e cinzas confirmam os estudos anteriores na Amazônia, de que sua contribuição para o carbono de longa duração é bastante reduzida.

A alta variabilidade estrutural da floresta é, em grande parte, responsável pelos diferentes coeficientes de combustão na Amazônia. Assim, torna-se necessário um maior número de estimativas em outras localidades a fim de obter-se uma média representativa para a região.

A amostragem pela linha de interseção mostrou-se bastante eficiente, indicando que métodos indiretos são uteis para facilitar o difícil trabalho de campo na pesagem da biomassa vegetal.

A queima da fitomassa da floresta teve pouco efeito sobre a matéria orgânica do solo. Verificou-se um aumento, estatisticamente não significativo, no teor de carbono do solo, imediatamente, após a prática de corte e queima da floresta. Após um ano a tendência foi de decréscimo.

A liberação de carbono pela queima inicial da biomassa florestal na Amazônia, sem considerar a parte que será liberada pelos processos de decomposição e requeima, tem uma importância significativa nas emissões globais de carbono. 


\section{REFERÊNCIAS BIBLIOGRÁFICAS}

ANDREA, M.O.; BROWELL, E.V.; GARSTANG, M.; GREGORY, G.L; HARRISS, R.C.; HILL, G.F.; JACOB, D.J.; PEREIRA, M.C.; SACHSE, G.W.; SETZER, A.W.; SILVA DIAS, P.L.; TALBOT, R.W.; TORRES, A.L.; WOFSY, S.C. Biomassburning emissions and associated haze layers over Amazonia. Journal of Geophysical Research, v.93, n.D2, p.1509-1527, 1988.

ARAÚJO, A.P. de; JORDY FILHO, S.; FONSECA, W. N. da. A vegetação da Amazônia brasileira. In: SIMPÓSIO DO TRÓPICO ÚMIDO, 1., Belém, 1986. Anais. Belém: EMBRAPA, CPATU, p.135-152. (EMBRAPA-CPATU. Documentos, 36).

ARAÚJO, T.M. Investigação das taxas de dióxido de carbono gerado em queimadas na região Amazônica. Guaratinguetá, 1995. 212p. Tese (Doutorado) - Faculdade de Engenharia de Guaratinguetá, Universidade Estadual Paulista.

ARRHENIUS, E.A.; WALTZ, T.W. The greenhouse effect: implications for economic development. Washington: World Bank, 1990. 18p. (Discussion paper $\mathrm{n}^{\mathrm{o}} 78$. International Bank for Reconstrution and Development)

ANDERSON, J.M.; INGRAM, J.SI., (Ed.). Tropical soil biology and fertility: a handbook of methods. 2 ed. Wallingford: CABI, 1993. 221p.

BASTOS, T. X.; DINIZ, T.D. de A.S. Avaliação do clima do Estado de Rondônia para o desenvolvimento agrícola. Belém: EMBRAPA, CPATU, 1982. 28p. (EMBRAPA-CPATU. Boletim de Pesquisa, 44).

BOGDONOFF, P.; DETWILER, R.P.; HALL, C.A.S. Land use change and carbon exchange in tropics: III. Struture, basic equations, and sensitivity analysis of the model. Enviromental Management, v.9, n.4, p.45-54, 1985.

BÖHRER, C.B. de; CAMPOS, A.N.S. Estimativa da biomassa florestal na Amazônia Legal a partir de dados provenientes de inventário florestal. In: CONGRESSO FLORESTAL BRASILEIRO, 7., Curitiba, 1993. Anais. Curitiba: SBS, SBEF, 1993. p.511-512. 
BOUWMAN, A.F. Soils and the greenhouse effect. In: BOUWMAN, A.F., (Ed.). Proceedings of the International Conference Soils and the Greenhouse effect. Chichester: Jonh \& Wiley, 1990. 575p.

BRINKMANN, W.L.F.; NASCIMENTO, J.C. The effect of slash and burn agriculture on plant nutrients in the tertiary region of central Amazonia. Turrialba, v.23, n.3, p.248-290, 1973.

BROWN, I.F.; MARTINELLI, L.A.; THOMAS, W.W.; MOREIRA, M.Z.; CID FERREIRA, C.A.; VICTORIA, R.A. Uncertainty in the biomass of Amazonian forests: An example from Rondônia, Brazil. Forest Ecology and Management, v.75, p.175-189, 1995.

BROWN, S.; LUGO, A.E. The storage and production of organic matter in tropical forests and their role in the global carbon cycle. Biotropica, v.4, n.3, p.161-187, 1982.

BROWN, S.; LUGO, A.E. Biomass of tropical forests: A new estimate based on forest volumes. Science, v.223, p.1290-1293, 1984.

BROWN, S.; LUGO, A.E. Aboveground biomass estimates for tropical moist forests of the Brazilian Amazon. Interciencia, v.17, n.1, p.8-18, 1992.

BROWN, S.; GILLESPIE, A.J.R.; LUGO, A.E. Biomass estimation methods for tropical forests with applications to forest inventory data. Forest Science, v.35, n.4, p.881$902,1989$.

BUSCHBACHER, R.J. Changes in productivity and nutrient cycling following conversion of Amazon rainforest to pasture. Athens, 1984. 193p. Thesis (Ph.D)Institute of Ecology, University of Georgia.

CERRI, C.C.; VOLKOFF, B.; ANDREUX, F. Nature and behaviour of organic matter in soils under natural forest, and after deforestation, burning and cultivation, near Manaus. Forest Ecology and Management, v.38, p.247-257, 1991.

CRUTZEN, P.J.; ANDREAE, M.O. Biomass burning in the tropics: Impact on atmospheric chemistry and biogeochemical cycles. Science. v.250, p.1669-1678, 1990. 
CUNNINGHAM, R.H. The effect of clearing a tropical forest soil. Journal of Soil Science, v.14, p.334-344, 1963.

DANTAS, M.; MATOS, A. de O. Estudos fito-ecológicos do trópico úmido brasileiro: III. Conteúdo de nutrientes em cinzas de floresta e capoeira, Capitão Poço, PA. Belém: EMBRAPA, CPATU, 1981. 23p. (EMBRAPA-CPATU. Boletim de Pesquisa, 24).

DETWILER, R.P. Land use change and the global carbon cycle: the role of tropical soils. Biogeochemistry, v.12, p.67-93, 1986.

DETWILER, R.P.; HALL, C.A.S. Tropical forests and global carbon cycle. Science, v.239, p.42-47, 1988.

DE VRIES, P.G. Multi-stage line intersect sampling. Forest Science, v.20, p.129-133, 1974.

DIXON, R.K.; BROWN, S.; HOUGHTON, R.A.; SOLOMON, A.M.; TREXLER, M.C.; WISNIEWSKI, J. Carbon pools and flux of global forest ecosystems. Science, v.263, p.185-190, 1994.

EMPRESA BRASILEIRA DE PESQUISA AGROPECUÁRIA. Mapa de solos do Brasil. Rio de Janeiro: Serviço Nacional de Levantamento e Conservação de Solos, 1981. Escala 1: 5.000 .000 .

EWEL, J.; BERISH, C.; BROWN, B.; PRICE, N.; RAICH, J. Slash and burn impacts on a Costa Rican wet forest site. Ecology, v.62, p.816-829, 1981.

FALESI, C.I. Ecossistemas de pastagem cultivada na Amazônia Brasileira. Belém: EMBRAPA, CPATU, 1976. 193p.

FEARNSIDE, P.M. The effects of cattle pasture on soil fertility in the Brazilian Amazon: Consequences for beef production sustainability. Tropical Ecology, v.21, n.1, p.125137, 1980.

FEARNSIDE, P.M. Deforestation in the Brazilian Amazon: how fast is it occuring? Interciencia, v.7, p.82-88, 1982.

FEARNSIDE, P.M. Brazil's Amazon forest and the global carbon problem. Interciencia, v.10, n.4, p.179-186, 1985. 
FEARNSIDE, P.M. Brazil's Amazon forest and the global carbon problem: reply to Lugo and Brown. Interciencia, v.11, n.2, p.58-64, 1986.

FEARNSIDE, P.M. Burn quality prediction for simulation of agricultural system of Brazil's Transamazon highway colonists. Turrialba, v.2, p.229-235, 1989.

FEARNSIDE, P.M. Fire in the tropical rain forests of the Amazon basin, In: GOLDAMMER, J.G. (Ed.). Fire in the tropical biota: ecosystem processes and global challenges. Heidelberg: Springer-Verlag, 1990a. p.106-116.

FEARNSIDE, P.M. The rate and extent of deforestation in Brazilian Amazonia. Environmental Conservation, v.17, n.3, p.213-226, 1990b.

FEARNSIDE, P.M. Carbon emissions and sequestration in forests: case studies from developing countries. In: Makundi, W.; Sathaye, J. (Ed.). Greenhouse gas emissions from deforestation in the Brazilian Amazon. Berkeley: Environmental Protection Agency; Lawrence Berkeley Laboratory, University of California, 1992a, vol. 2, 73p.

FEARNSIDE, P.M. Forest biomass in brazilian Amazônia: comments on the estimate by Brown and Lugo. Interciencia, v.17, n.1, p.19-27, 1992b.

FEANSIDE, P.M. Greenhouse gas contributions from deforestation in Brazilian Amazonia. In: LEVINE, J.S. (Ed.). Global biomass burning: atmospheric, climatic, and biospheric implications. Boston: MIT Press, 1991. p.92-105.

FEARNSIDE, P.M. Deforestation in Brazilian Amazonia: the effect of population an land tenure. Ambio, v.22, n.8, p.537-545, 1993.

FEARNSIDE, P.M. Biomassa das florestas Amazônicas brasileiras. In: SEMINÁRIO EMISSÃO $\mathrm{X}$ SEQÜESTRO DE $\mathrm{CO}_{2}$ : UMA NOVA OPORTUNIDADE DE NEGÓCIOS PARA O BRASIL, Porto Alegre, 1994. Anais. Rio de Janeiro: CVRD, 1994. p.96-123.

FEARNSIDE, P.M. Amazonian and global warming: annual balance of greenhouse gas emissions from land use change in Brazil's Amazon region. In: LEVINE, J, (Ed.). Biomass burning and global change., Cambrigde: MIT Press, 1996. p.606-617. v.2: Southeast Asia, and Temperate and Boreal Ecosystems, and oil fires od Kuwait. 
FEARNSIDE, P.M.; FERRAZ, J. A conservation gap analysis of Brazil's Amazonian vegetation. Conservation Biology, v.9, n.5, p.1134-1147, 1995.

FEARNSIDE, P.M.; GUIMARÃES, W.M. Carbon uptake by secondary forests in Brazilian Amazonian. Forest Ecology and Management. v.80, p.35-46, 1996.

FEARNSIDE, P.. M.; LEAL FILHO, N.; FERNANDES, F.M. Rainforest burning and global carbon bugdet: biomass, combustion efficiency, and charcoal formation in the Brazilian Amazon. Journal of Geophysical Research, v.98, n.D9, p.16733-16743, 1993.

FEARNSIDE, P.M.; TARDIN, A.T.; MEIRA FILHO, L.G. Deforestation rate in Brazilian Amazonia. São José dos Campos: Instituto Nacional de Pesquisas Espaciais, 1990. 8p.

GOLLEY, F.B.; ODUM, H.T.; WILSON, R.F. The structure and metabolism of a Puerto Rican red mangrove forest in May. Ecology, v.43, n.1, p.9-19, 1962.

GOLLEY, F.B.; MCGINNIS, J.T.; CLEMENTS, R.G.; CHILD, G.I.; DUEVER, M.J. Ciclagem de minerais em um ecossistema de floresta tropical tropical úmida. São Paulo: EPU/EDUSP, 1978. 256 p.

GOMES, B.M. Estudo paleoambiental no estado de Rondônia utilizando datação por ${ }^{14} \mathrm{C}$ e razão ${ }^{13} \mathrm{C} /{ }^{12} \mathrm{C}$ da matéria orgânica do solo. Piracicaba, 1995. 100p. Dissertação (Mestrado) -Centro de Energia Nuclear na Agricultura, Universidade de São Paulo .

GONÇALVES, J.L. de M.; MORO, L. Uso da "cinza" de biomassa florestal como fonte de nutrientes em povoamentos puros de Eucaliptus grandis. IPEF, v.48/47, p.28-37, 1995.

GUILlaUmET, J, L. Some structural and floristic aspects of the forest. Experientia, v.43, p.241-250, 1987.

HASE, H.; FOELSTER, H.; LINDHEIM, M. On the acuracy of estimating aboveground tree biomass in an evergreen forest near Manaus, Brazil. A simulatiom study. Biotropica, v.17, n.3, p.191-195, 1985. 
HECHT, S.B. Cattle ranching development in the Eastern Amazon: evaluation of a development policy. Berkeley, 1982. 454p. Thesis (Ph.D) - University of Califonia.

HERNANI, L.C.; SAKAI, E.; ISHIMURA, I.; LEPSCH, I.F. Influência de métodos de limpeza de terreno sob floresta secundária em latossolo amarelo do Vale do Ribeira, SP. I. Dinâmica de atributos químicos, físicos e produção de milho. Revista Brasileira de Ciência do Solo, v.11, n.2, p.205-213, 1987.

HIGUCHI, N.; CARVALHO JUNIOR, J.A. Fitomassa e conteúdo de carbono de espécies arbóreas da Amazônia. In: SEMINÁRIO EMISSÃO X SEQÜESTRO DE $\mathrm{CO}_{2}$ : UMA NOVA OPORTUNIDADE DE NEGÓCIOS PARA O BRASIL. Porto Alegre, 1994. Anais. Rio de Janeiro: CVRD, 1994, p.125-153.

HIGUCHI, N.; SANTOS, J.M.; IMANGA, M.; YOSHIDA, S. Aboveground biomass estimate for amazonian dense tropical moist forests. Memorial Faculty of Agriculture of Kagoshima University, v.30, p.43-54, 1994.

HONZÁK, M.; LUCAS, R.M.; AMARAL DO I.; CURRAN, P.J.; FOODY, G.M.; AMARAL, S. Estimation of the leaf area index and total biomass of tropical regenerating forests: comparision of methodologies. In: GASH, J.H.C.; NOBRE, C.A.; ROBERTS, J.M.; VICTORIA, R.L., (Ed.). Amazonian deforestation and climate. Chichester: John Wiley, 1996. cap.21, p.365-381.

HOUGHTON, R.A. The global effects of tropical deforestation. Environmental Science Technology, v.24, n.4, p.414-22, 1990.

HOUGHTON, R.A. Tropical deforestation and atmospheric carbon dioxide. Climatic Change, v.19, p.99-118, 1991

HOUGHTON, R.A. As florestas e o ciclo de carbono global: armazenamento e emissões atuais. In: SEMINÁRIO EMISSÃO X SEQÜESTRO DE $\mathrm{CO}_{2}$ : UMA NOVA OPORTUNIDADE DE NEGÓCIOS PARA O BRASIL. Porto Alegre, 1994. Anais. Rio de janeiro: CVRD, 1994, p.39-76.

HOUGHTON, R.A. Converting terrestrial ecosystems from sources to sinks of carbon. Ambio, v.25, n.4, p.267-272, 1996. 
INSTITUTO NACIONAL DE PESQUISAS ESPACIAIS. Levantamentos das áreas desflorestadas na Amazônia Legal no período 1991-1994: resultados. São José dos Campos: INPE/FUNCATE, 1996. n.p. (Projeto Prodes).

INTERGOVERNAMENTAL PANEL ON CLIMATE CHANGE. Radiative forcing of climate change: The 1994 report of the scientific assessment working group of IPCC. Paris: WMO/UNEP, 1994, 27p. (Summary for policymakers).

JORDAN, C.F. Nutrient cycling in tropical forest ecosystems. New York: Jonh Wiley, 1985. 190p.

JORDAN, C.F.; UHL, C. Biomass of a "tierra firme" forest of the Amazon basin. Oecologia Plantarum, v.13, n.4, p.387-400, 1978.

KAISER, L. Unbiased estimation in line-intecept samplig. Biometrics, v. 39, p.965-976, 1983.

KAUFFMAN, J.B.; CUMMINGS, D.L.; WARD, D.E. Relationships of fire, biomass and nutrient dynamics along a vegetation gradient in the Brazilian cerrado. Journal of Ecology, v.82, p.519-531, 1994.

KAUFFMAN, J.B.; CUMMINGS, D.L.; WARD, D.E.; BABBIT, R. Fire in the Brazilian Amazon: 1. Biomass, nutrient pools, and losses in slashec primary forests. Oecologia, v.104, p.397- 408, 1995.

KAUFFMAN, J.B.; UHL, C.; CUMMINGS, D.L. Fire in the Venezuelan Amazon 1: fuel biomass and fire chemistry in the evergreen rainforest of Venezuela. Oikos, v.53, p.167-175, 1988.

KELLER, M.; KAPLAN, W.A; WOFSY, S.C. Emissions of $\mathrm{N}_{2} \mathrm{O}, \mathrm{CH}_{4}$, and $\mathrm{CO}$ from tropical forest soil. Journal of Geophysical Research, v.91, p.1792-1802, 1986.

KIRCHHOFF, V.W.J.H. Queimadas na Amazônia e efeito estufa. São Paulo: Editora Contexto, 1992. $111 \mathrm{p}$.

KLINGE, H.; RODRIGUES, W.A.; BRUNIG, E.; FITTKAU, E.J. Biomass and structure in a Central Amazonian rain forest. In: GOLLEY, F.B.; MEDINA, E., (Ed.). Tropical ecological Systems: trends in terrestrial and aquatic research.. New York: Springer Verlag, 1975. cap. 9, p.115-122. 
KLINGE, H.; HERRERA, R. Phytomass structure of natural plant comunities on spodosols in southern Venezuela: the tall Amazon caatinga forest. Vegetatio, v.53, p.65-84, 1983.

KLINGE, H.; JUNK, W.J.; REVILLA, C.J. Status and distribution of forested wetlands in tropical South America. Forest Ecology and Management, v.33/34, p.81-101, 1990.

LEOPOLDO, P.R.; FRANKEN, W.; SALATI, E.; RIBEIRO, M.N. Towards a water balance in the central Amazonian region. Experientia, v.43, p.223-233, 1987.

LUGO, A.E.; BROWN, S. Brazil's Amazon forest and the global carbon problem. Interciencia, v.11, p.57-58, 1986.

MAHAR, D.J. Government policies and deforestation in Brazil's Amazon region. Washington: World Bank, 1989. 56p.

MARTINELLI, L.A.; VICTORIA, R.L.; RICHEY, J.E.; MORTATTI, J; DEVOL, A.H. The Amazon basin: deforestation and $\mathrm{CO}_{2}$ emissions. In: LAL, M., (Ed.). Global warming concern for tomorrow. New Delhi: McGraw-Hill, 1993. cap.12, p.174195.

MARTINS, P.F.S. Consequências do desmatamento sobre o solo de um ecossistema de terra firme da Amazônia oriental. Piracicaba, 1987. 233p. Tese (Doutorado) - Escola Superior de Agronomia "Luiz de Queiroz", Universidade de São Paulo.

MARTINS, P.F.S.; CERRI, C.C.; VOLKOFF, B.; ANDREUX, F. Efeito do desmatamento e do cultivo sobre as características físicas e químicas do solo sob floresta natural na Amazônia oriental. Revista IG., v.8-10, n.1, p.21-33, 1990.

McKANE, R.B.; RASTETTER, E.B.; MELLILO, J.M.; SHAVER, G.R.; HOPKINSON, C.S.; FERNANDES, D.N.; SKOLE, D.L.; CHOMENTOWSKI, W.H. Effects of global change on carbon storage in tropical forests of South America. Global Biogeochemical Cycle, v.9, n.3, p.329-350, 1995.

MELLILO, J.M.; KICKLIGHTER, D.W.; MOORE III, B.; VOROSMARTY, C.J.; SCHLOSS, A.L. Global climate change and terrestrial net primary production. Nature, v.363, p.234-240, 1993. 
MORAES, J.L.; CERRI, C.C.; MELLILO, J.M.; KICKLIGHTER, D.; NEILL, C., SKOLE, D.L.; STEUDLER, P.A. Soil carbon stocks of the Brazilian Amazon basin. Soil Science Society of America Journal, v.59, n.1, p.244-247, 1995.

MORAES, J.L.; VOLKOFF, B.; CERRI, C.C.; BERNOUX. Soils properties under Amazon forest abd changes due to pasture installation in Rondônia, Brazil. Geoderma, v.70, p.63-81, 1996.

MYERS, N. Deforestation rates in tropical forests and theirs climatic implications. London: Friends of the Earth, 1989. $116 \mathrm{p}$.

MYERS, N. Tropical forest. In: LEGGETT, J., (Ed.). Global warming: the Greenpeace report. Oxford: Oxford University Press, 1990. p.372-399.

NEILL, C.; MELLILO, J.M.; CERRI, C.C.; STEUDLER, P.A.; MORAES, J.L.; PICCOLO, M.C., BRITO, M.P.M. Soil organic matter stocks following forest clearing for pasture in the Brazilian Amazon. Ecological Applications, (no prelo).

NELSON, B.W. Diversidade florística de ecossistemas amazônicos. Revista do Instituto Florestal, v.4, p.111-118, 1992.

NELSON, R.; SWIFT, R., KRABILL, W. Using airborne lasers to estimate forest canopy and stand characteristics. Journal of Forestry, v.86, n.10, p.31-38, 1988.

NYE, P.H.; GREENLAND, D.J. Changes in the soil after clearing tropical forest. Plant and Soil, v.21, n.1, p.101-112, 1964.

OLSON, J.S; WATTS, J.A.; ALLISON, L.J. Carbon in live vegetation of major world ecosystems. Oak Ridge: ORNL/Union Carbide,1983. 164 p.

OVERMAN, J.P.M.; WITTE, H.J.L.; SALDARRIAGA, J.G. Evaluation of regression models for above-ground biomass determination in Amazon rainforest. Journal of Tropical Ecology, v.10, p.207-218, 1994.

PIRES, J.M. The forest ecosystems of the Brazilian Amazon: description, functioning and research needs. In: UNESCO. Tropical forest ecosystems. Vendome: Unesco/Presses Universitaires de France. 1978. Cap.13, p.607-627: 
PIRES, J.M.; PRANCE, G.T. The vegetation types of Brazilian Amazon. In: PRANCE, G.T.; LOVEJOY, T.E., (Ed.). Key enviroments: Amazonia. New York: Pergamon Press, 1985. cap. 7, p. 109-145.

PRANCE, G.T. The origen and evolution of the Amazon flora. Interciencia, v.3, n.4, p.207-222, 1978.

PROJETO RADAMBRASIL. Levantamento de Recursos Naturais. Rio de Janeiro: Ministério das Minas e Energia. Departamento Nacional de Produção Mineral., 19731983, Vol. 1-27.

REINEIRS, W.A.; BOUWMAN, A.F.; PARSONS, W.F.J.; KELLER, M. Tropical rain forest conversion to pasture: changes in vegetation and soil properties. Ecological Applications, v.4, n.2, p.363-377, 1994.

SADER, S.A.; WAIDE, R.B.; LAWRENCE, W.T.; JOYCE, A.T. Tropical forest biomass and successional age class relationships to a vegetation index derived from Landsat TM data. Remote Sensing Environmental. v.28, p.143-156, 1989.

SÁNCHEZ, P.A. Soil Management in shifting cultivation areas. In: SÁNCHEZ, P.A., (Ed.). Properties and management of soils in the tropics. New York: John Wiley, 1976. cap.10, p.346-412.

SÁNCHEZ, P.A.; VILLACHICA, J.H.; BANDY, D.E. Soil fertility dynamics after clearing a tropical rainforest in Peru. Soil Science Society of America Journal, v.47, p.1171-1178, 1983.

SANFORD, JR. R.L.; SALDARRIAGA, J.; CLARK, K.E.; UHL, C.; HERRERA, R. Amazon rain-forest fires. Science, v.227, p.53-55, 1985.

SCHROEDER, P.E.; WINJUM, J.K. Assessing Brazil's carbon budget: I. Biotic carbon pools. Forest Ecology and Management, v.75, p.77-86, 1995.

SEILER, W.; CRUTZEN, P.J. Estimates of gross and net fluxes of carbon between the biosphere and the atmosphere from biomass burning. Climatic Change, v.2, p.207$247,1980$.

SETZER, A.W.; PEREIRA, M.C. Amazonia biomass burnings in 1987 and an estimate of their tropospheric emissions. Ambio, v.20, n.1, p.19-22, 1991. 
SEUBERT, C.E.; SANCHEZ, P.A.; VALVERDE, C. Effects of land clearing methods on soil properties of an ultisol and crop performance in the Amazon jungle of Peru. Tropical Agriculture, v.54, n.4, p.307-321, 1977.

SMYTH, T.J.; BASTOS, J.B. Alterações na fertilidade de um latossolo amarelo álico pela queima da vegetação. Revista Brasileira de Ciência do Solo, v.8, p.127-132, 1984.

SOMBROEK, W.G. Biomass and carbon storage in the Amazon ecosystems. Interciencia, v.17, n.5, p.269-272, 1992.

SUPERINTENDÊNCIA DO DESENVOLVIMENTO DA AMAZÔNIA \& FUNDAÇÃO INSTITUTO BRASILEIRO DE GEOGRAFIA E ESTATÍSTICA. Amazônia Legal: mapa de vegetação. Brasilia: Ministério do Interior/Secretaria do Planejamento e Coordenação da Presidência da República, 1989. Escala 1:2.500.000. TARDIN, A.T.; LEE, D.C.L.; SANTOS, R.J.R.; DE ASSIS, O.R.; BARBOSA, M.P.S.; MOREIRA, M.L.; PEREIRA, M.T.; SILVA, D.; SANTOS FILHO, C.P. Subprojeto Desmatamento Convênio IBDF/CNPq-INPE 1979. São José dos Campos: Instituto Nacional de Pesquisas Espaciais, 1980. 44 p.(Relatório ${ }^{2}$ INPE-RPE/103). TEIXEIRA, L.B.; BASTOS, J.B. Matéria orgânica nos ecossistemas de floresta primária e pastagens na Amazônia Central. Belém:EMBRAPA, CPATU,1989. 26p. (EMBRAPA-CPATU. Boletim de Pesquisa, 99).

TRUGUILHO, P.F.; SILVA, D.A. da; FRAZÃO, F.J.L.; MATOS, J.L.M. de. Comparação de métodos de determinação de densidade básica em madeira. Acta Amazonica, v.20(único), p.307-319, 1990.

TRUMBORE, S.E.; DAVIDSON, E.A; CAMARGO, P.B. de; NEPSTAD, D.C.; MARTINELLI, L.A. Bellowground cycling of carbon in forests and pastures of Eastern Amazonia. Global Biogeochemical Cycles, v.9, n.4, p.515-528, 1995. UHL, C.; KAUFFMAN, J.B. Deforestation, fire susceptibility, and potential tree responses to fire in the eastern Amazon. Ecology, v.71, n.2, p.437-449, 1990. 
UHL, C.; KAUFFMAN, J.B.; CUMMINGS, D.L. Fire in the Venezuelan Amazon 2: environmental conditions necessary for forest fires in the evergreen rainforest of Venezuela. Oikos, v.53, p.176-184, 1988.

VELOSO, H.P.; JAPIASSÚ, A.M.S.; GÓES FILHO, L; LEITE, P.F. As regiões fitoecológicas, sua natureza e seus recursos econômicos. In: PROJETO RADAMBRASIL. Folha SD.22 Araguaia e parte de SC.22 Tocantins. Rio de Janeiro: Ministério das Minas e Energia, 1974. p.IV/1-IV/119. (Levantamento de recursos naturais, 4).

VELOSO, H.P.; GÓES FILHO, L.; LEITE, P.F.; SILVA, S.B.; FERREIRA, H.C.; LOUREIRO, R.L.; TEREZO, E.F.M. As regiões fitoecológicas, sua natureza e seus recursos econômicos: estudo fitogeográfico. In: PROJETO RADAMBRASIL. Folha NA.20 Boa Vista e parte das folhas NA.21 Tumucumaque, NB.20 Roraima e NB.21. Rio de Janeiro: Ministério das Minas e Energia,1975. cap.IV, p.305-403. (Levantamento de recursos naturais, 8).

VIEIRA, L.S.; SANTOS, P.C.T.C. dos. Amazônia: seus solos e outros recursos naturais. São Paulo: Editora Agronômica Ceres, 1987. 416 p.

VAN WAGNER, C.E. The line intersect method for forest fuel sampling. Forest Science, v. 14, n.1, p. 20-26, 1968.

WARREN, W.G.; OLSEN, P.F. A line intersect technique for assessing logging waste. Forest Science, v.10, n.3, p.267-276, 1964.

WONG, C.S. Atmospheric input of carbon dioxide from burning wood. Science, v.200, p.197-200, 1978.

ZINKE, P.J.; SABHASRI, S.; KUNSTADTER, P. Soil fertility aspects of the Lua' forest fallow system of shifting cultivation. In: KUNSTADTER, P; CHAPMAN, E.C.; SABHASRI, S., (Ed.). Farmers in the forest. Honolulu: University Press of Hawaii, 1970. cap.7, p.134-159. 